\title{
RECFIVED
}

APR $\cap 11990$

\section{OS I1}

Effect of Composition and Temperature on the Properties of High-Level Waste (HLW) Glass Melting Above $1200^{\circ} \mathrm{C}$ (DRAFT)
J. D. Vienna
G. F. Peipel
P. R. Hrma
D. E. Smith
M. J. Schweiger
C. Y. Chang
M. H. Langowski
D. E. Rinehart
P. E. Redgate
S. E. Palmer
D. S. Kim
H. Li

February 1996

Prepared for

the U.S. Department of Energy

under Contract DE-AC06-76RLO 1830

Pacific Northwest National Laboratory

Richland, Washington 99352 
PNNL-10987

UC-810

Project Technical Information

\section{Effect of Composition and Temperature on the Properties of High-Level Waste (HLW) Glasses Melting Above ${ }^{1200^{\circ} \mathrm{C} \text { (Draft) }}$}
J. D. Vienna
G. F. Piepel
P. R. Hrma
D. E. Smith
M. J. Schweiger
C. Y. Chang
M. H. Langowski
D. E. Rinehart
P. E. Redgate
S. E. Palmer
D. S. Kim
H. Li

February 1996

Prepared for

the U.S. Department of Energy

under Contract DE-AC06-76RLO 1830

Pacific. Northwest National Laboratory

Richland, Washington 99352 


\title{
DISCLAIMER
}

This report was prepared as an account of work sponsored by an agency of the United States Government. Neither the United States Government nor any agency thereof, nor Battelle Memorial Institute, nor any of their employees, makes any warranty, express or implied, or assumes any legal liability or responsibility for the accuracy, completeness, or. usefulness of any information, apparatus, product, or process disclosed, or represents that its use would not infringe privately owned rights. Reference herein to any specific commercial product, process, or service by trade name, trademark, manufacturer, or otherwise does not necessarily constitute or imply its endorsement, recommendation, or favoring by the United States Government or any agency thereof, or Battelle Memorial Institute. The views and opinions of authors expressed herein do not necessarily state or reflect those of the United States Government or any agency thereof.

\author{
PACIFIC NORTHWEST NATIONAL LABORATORY \\ operated by \\ BATTELLE \\ for the \\ UNITED STATES DEPARTMENT OF ENERGY \\ under ContraCt DE-ACO6-76RLO 1830
}

\author{
Printed in the Uniled States of America \\ Available to DOE and DOE contractors from the \\ Office of Scientific and Technical Information, P.O. Box 62, Oak Ridge, TN 37831; \\ prices available from (615) $576-8401$.
}

Available to the public from the National Technical Information Service, U.S. Department of Commerce, 5285 Port Royal Rd., Springfield, VA 22161 


\section{Summary}

Increasing the melting temperature of HLW glass allows an increase of waste loading (thus reducing product volume) and the production of more durable glasses at a faster melting rate. However, HLW glasses that melt at high temperatures differ in composition from glasses foimulated for low temperature $\left(-1150^{\circ} \mathrm{C}\right)$. Consequently, the composition of high-temperature glasses falls in a region previously not well tested or understood. This report represents a preliminary study of property/composition relationships of high-temperature Hanford HLW glasses using a one-component-at-a-time change approach.

A test matrix has been designed to explore a composition region expected for hightemperature high-waste loading $\mathrm{HLW}$ glasses to be produced at Hanford. This matrix was designed by varying several key components ( $\mathrm{SiO}_{2}, \mathrm{~B}_{2} \mathrm{O}_{3}, \mathrm{Na}_{2} \mathrm{O}, \mathrm{Li}_{2} \mathrm{O}, \mathrm{Fe}_{2} \mathrm{O}_{3}, \mathrm{Al}_{2} \mathrm{O}_{3}, \mathrm{ZrO}$, $\mathrm{Bi}_{2} \mathrm{O}_{3}, \mathrm{P}_{2} \mathrm{O}_{5}, \mathrm{UO}_{2}, \mathrm{TiO}_{2}, \mathrm{Cr}_{2} \mathrm{O}_{3}$, and Others) starting from a glass based on a Hanford HLW allblend waste. Glasses were fabricated and tested for viscosity, glass transition temperature, electrical conductivity, crystallinity, liquidus temperature, and PCT release. The effect of individual components on glass properties was assessed using first- and second-order empirical models. The first-order component effects were compared with those from low-temperature HLW glasses. 


\section{Table of Contents}

1.0 Introduction $\ldots \ldots \ldots \ldots \ldots \ldots \ldots \ldots \ldots \ldots \ldots \ldots \ldots, 1$

2.0 Mathematical Modelling $\ldots \ldots \ldots \ldots \ldots \ldots \ldots \ldots \ldots \ldots \ldots \ldots, 3$

3.0 Experimental Approach $\ldots \ldots \ldots \ldots \ldots \ldots \ldots \ldots \ldots \ldots \ldots \ldots, 4$

4.0 Process Related Properties $\ldots \ldots \ldots \ldots \ldots \ldots \ldots \ldots \ldots \ldots \ldots \ldots, 6 \ldots \ldots$

4.1 Melting Témperature $\ldots \ldots \ldots \ldots \ldots \ldots \ldots \ldots \ldots \ldots \ldots, 7$

4.2 Vogel - Fulcher - Tammann Relationship $\ldots \ldots \ldots \ldots \ldots \ldots \ldots \ldots, 10$

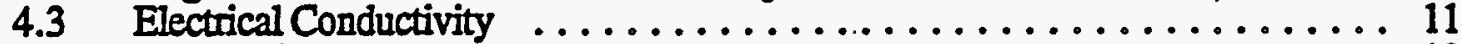

4.4 Length $\ldots \ldots \ldots \ldots \ldots \ldots \ldots \ldots \ldots \ldots \ldots \ldots \ldots, 12$

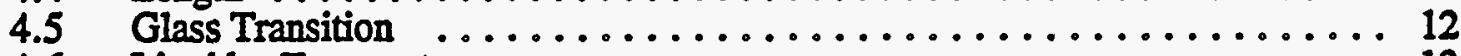

4.6 Liquidus Temperature $\ldots \ldots \ldots \ldots \ldots \ldots \ldots \ldots \ldots \ldots \ldots \ldots, 13$

5.0 Product Characterization $\ldots \ldots \ldots \ldots \ldots \ldots \ldots \ldots \ldots \ldots \ldots \ldots \ldots \ldots$

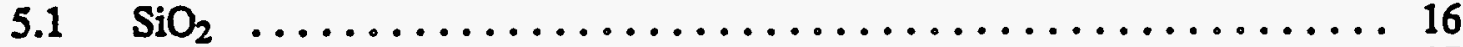

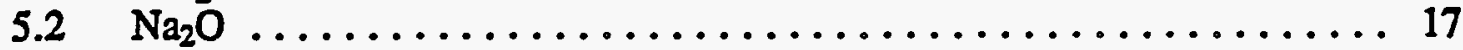

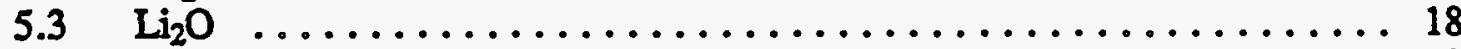

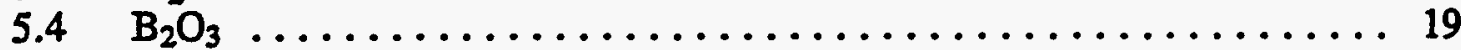

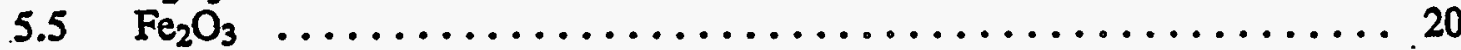

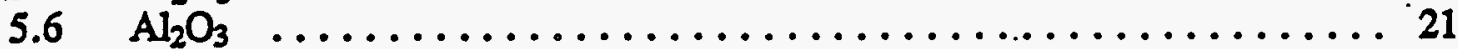

$5.7 \mathrm{ZrO}_{2} \ldots \ldots \ldots \ldots \ldots \ldots \ldots \ldots \ldots \ldots \ldots \ldots \ldots \ldots \ldots \ldots \ldots \ldots \ldots \ldots \ldots \ldots \ldots, 22$

5.8 Others $\ldots \ldots \ldots \ldots \ldots \ldots \ldots \ldots \ldots \ldots \ldots \ldots \ldots \ldots \ldots \ldots \ldots \ldots \ldots \ldots \ldots \ldots \ldots, 23$

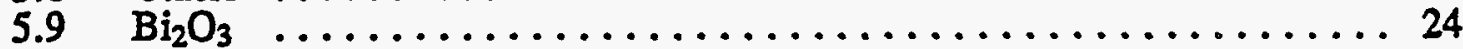

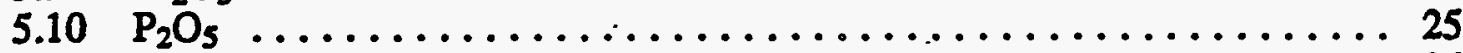

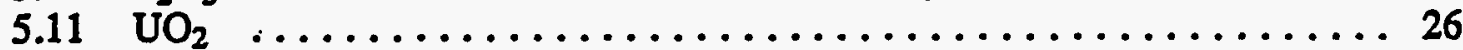

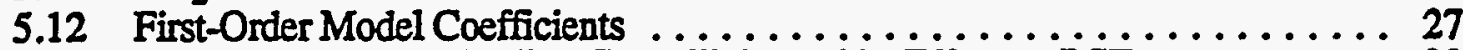

5.13 Canister Centerline Cooling Crystallinity and its Effect on PCT $\ldots \ldots \ldots \ldots 30$

6.0 Property Modelling $\ldots \ldots \ldots \ldots \ldots \ldots \ldots \ldots \ldots \ldots \ldots \ldots \ldots \ldots \ldots \ldots \ldots \ldots$

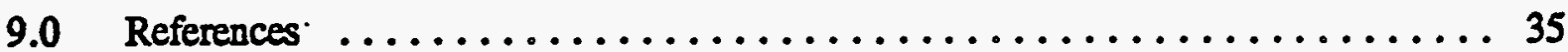

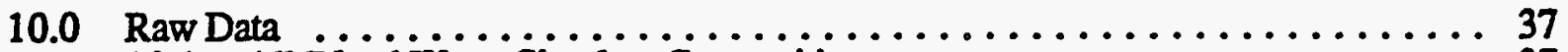

10.1. All-Blend Waste Simulant Composition $\ldots \ldots \ldots \ldots \ldots \ldots \ldots \ldots, 37$

10.2 Viscosity Temperature Table $\ldots \ldots \ldots \ldots \ldots \ldots \ldots \ldots \ldots \ldots, 38$

10.3 Electrical Conductivity Temperature Table $\ldots \ldots \ldots \ldots \ldots \ldots \ldots \ldots, 43$

10.4 Crystallinity and Liquidus Temperature Results $\ldots \ldots \ldots \ldots \ldots \ldots \ldots \ldots, 47$

10.5 PCT Normalized Releases for Each Glass $\ldots \ldots \ldots \ldots \ldots \ldots \ldots \ldots, 50$ 


\subsection{Introduction}

High-Level Waste (HIW) at Hanford will be converted into a vitrified form for disposal in a geological repository. Nearly $230,000 \mathrm{~m}^{3}$ (61 million gallons) of nuclear waste are stored at Hanford in 28 double shell tanks (DSTs) and 149 single shell tanks (SSTs). These wastes will be separated into HLW and LoW-Level Waste (LLW) and vitrified. Current Tank Waste Remediation System (TWRS) flowsheets indicate that wastes from DST'S and SST's will first be blended, pretreated by sludge washing, and separated into HLW and LLW fractions for vitrification.

To formulate glasses for HLW vitrification, the Composition Variation Study (CVS) was undertaken. This study was undertaken to measure and model glass properties as a function of composition. This effort initially focused on glasses expected to be melted at $1150^{\circ} \mathrm{C}$ containing. 25 to 28 wt\% of pretreated Hanford Double Shell Tank (DST) Waste, in particular, Neutralized Current Acid Waste (NCAW). The study results are discussed in detail by Hrma and Piepel et al. (1994) and are referred to extensively here.

Characterization of tank wastes is still in progress and pretreatment processes are under development. The chemical compositions of the pre-treated wastes will likely differ considerably from current estimates. Uncertainty in waste composition exists from tank-to-tank variations, tank composition characterization uncertainty, and undecided pretreatment and blending processes, and process control considerations. This uncertainty can be addressed by developing models that can be used for glass formulation over the range of HLW compositions expected to be vitrified at Hanford. Such composition variation (composition envelope) studies constitute a part of the overall glass formulation strategy for addressing HLW vitrification needs. The strategy also involves performing more detailed studies of selected waste composition estimates to determine solubility, crystallinity, or other limits on waste loading. Knowledge of such limits and the ability to formulate glasses over composition regions appropriate for Hanford site wastes are needed to support waste blending and pretreatment decisions. Once such decisions are made and waste types to be processed by a Hanford HLW vitrification plant are selected, glass formulation efforts can then focus on developing robust glass compositions for these waste types.

The fraction of waste oxides or waste loading (WL) in Hanford waste glass will ultimately influence the cleanup cost. Increasing WL should reduce the time to process waste, which will decrease the cost of materials, equipment, and labor. Immobilized waste volume and repository space will also be reduced by increased WL. It is estimated that waste disposal in a repository will make up a large fraction of nuclear waste cleanup costs (Merrill and Chapman, 1994). Maximum WL must be compatible with processing and product acceptability requirements imposed on glass. Waste loading is limited by processing requirements through melting and liquidus temperatures ( $T_{M}$ and $T_{L}$, respectively) or melt segregation. Product quality limits waste loading through a restriction on product durability.

Experience has shown that the restriction $T_{L} \leq T_{M}-100^{\circ} \mathrm{C}$, generally accepted as the $T_{L}$ limit for continuous melters, will constrain the WL for a majority of Hanford high level wastes (see Lambert and Kim 1994 and Hrma and Vienna 1995). In this case, the maximum waste loading will be determined as the point with the highest waste loading while maintaining a separation of $100^{\circ} \mathrm{C}$ between the curves of $T_{L}$ and $T_{M}$. These temperatures can be measured or predicted using thermodynamic and property/composition models, respectively. Although $T_{L}$ tends to increase with WL, the difference between $T_{L}$ and $T_{M}$ decreases with waste loading for several Hanford waste composition estimates. If $T_{M}$ is further restricted by low temperature processing technology, then WL is also limited. Additional processing constraints may further limit WL. Some commonly encountered constraints are discussed elsewhere, including: molten salt 
segregation (Li et al. 1995), immiscible phase separation (Peeler and Hrma 1994), and component solubility (Langowski et al. 1994, Li et al. 1995).

Higher melting temperature glasses are needed to increase WL in waste glass. In this regard property composition relationships must be studied in a different glass composition region than that used for lower temperature melting glasses. The four major differences between the composition region for low temperature glasses of the CVS and the high temperature glasses of the CVS are: 1) decreased boron concentration, 2) increased refractory concentration (i.e. Al, Fe, and $\mathrm{Zr}$ ), 3) larger range of $\mathrm{SiO}_{2}$ concentrations, and 4) different "Others" composition. These differences are shown in the composition summary table below. In addition to these four compositional changes, $\mathrm{P}_{2} \mathrm{O}_{5}, \mathrm{Bi}_{2} \mathrm{O}_{3}$, and $\mathrm{UO}_{2}$ have been added to the high-temperature phase of the study.

Table I. Composition range of CVS and HTM glasses in mass fractions.

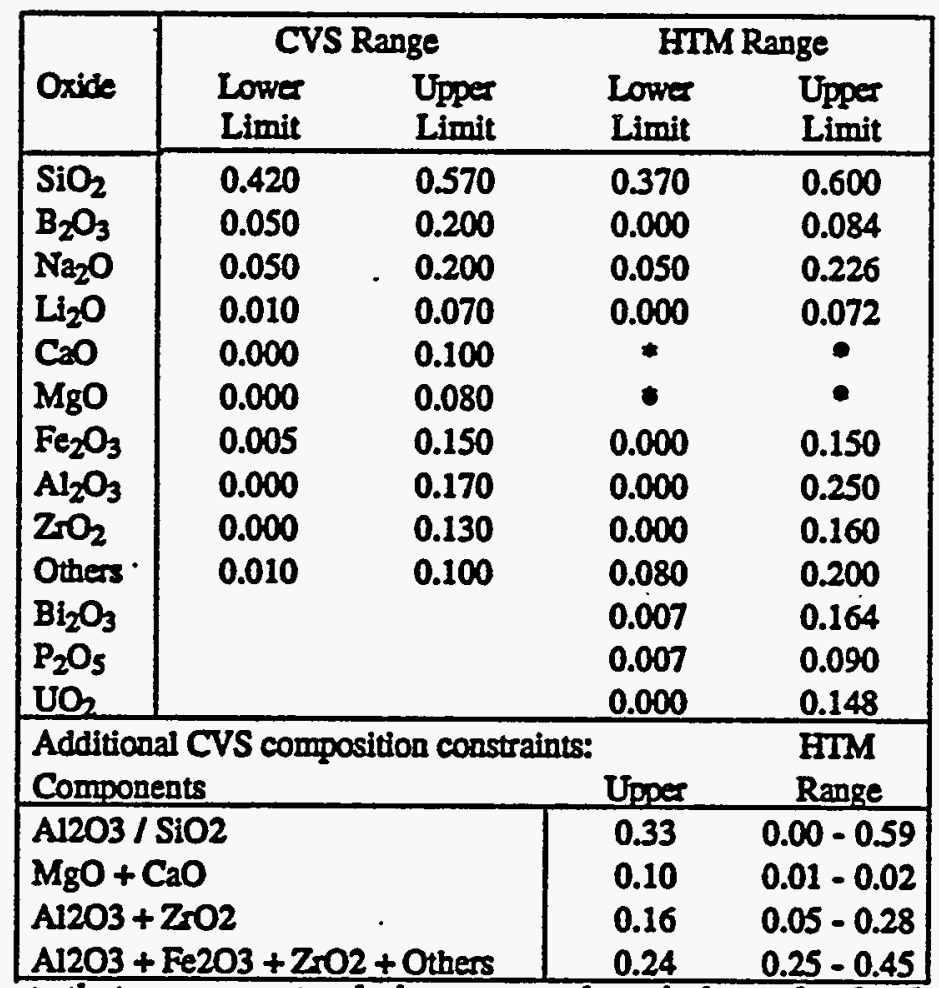

* indicates components that are present only in waste and not independently altered

The objective of this report is to describe the effects of composition on the following waste glass properties and characteristics: melting temperature $\left(T_{M}\right)$, viscosity $(\eta)$-temperature relationship, glass transition temperature $\left(T_{g}\right)$, electrical conductivity $(\varepsilon)$, liquidius temperature $\left(T_{L}\right)$, canister centerline cooling (CCC) crystallinity, and product consistency test (PCT) releases ( $r_{1}$ where $i$ indicates the $i-t h$ component release) from quenched and CCC glasses.

The effect of composition on glass properties can be expressed by means of first-order model coefficients, which correspond to partial specific properties (Hrma and Robertus 1993). Alternatively, component effects can be expressed in terms of the change in the property if a 
component is added to the mixture (glass). The effects can be described and used in several different ways. The effect of a single component can be taken as the slope at the zero addition point of a property versus component addition curve. The slope can then be converted into a firstorder model coefficient which is used to predict property values from glass composition. These models are used in several tasks including glass formulation, evaluation of blending and pretreatment scenarios, selection of melter technologies, HLW plant operation, and waste form qualification.

The work covered in this report is discussed in the test plan (Langowski et al. 1994). The completion of this report satisfies milestones PVTD-C95-02.01E and PVTD-C95-02.01J. The report is organized by property, then further broken down to components.

\subsection{Mathematical Modelling}

Currently, acceptable physical or theoretical modets relating glass properties to composition do not exist due to the complexity of glass chemistry. PNL therefore bases property modelling on theoretically justifiable mixture model forms with empirically fit coefficients (Hrma and Piepel et al. 1994). This method yields good property prediction capability for a given composition range where no discontinuities exist in properties. However, models must be fit to experimental data in the composition range of interest. Extrapolation outside of that range will dramatically increase the uncertainty of property predictions made with such models.

If glass is taken as a mixture of components, a mixture property $(\pi)$ depends on primary thermodynamic variables including temperature (T), pressure (P), and composition vector (g). Since $P$ is constant for glass melting operations, $\pi=f(T, g)$. Viscosity and electrical conductivity data were generated as a function of temperature in this study. The dependence of these properties on temperature follow the Vogel-Fulcher-Tammann (VFT) relationship:

$$
\dot{\ln (\pi)}=\mathrm{A}(\mathrm{g})+\frac{\mathrm{B}(\mathrm{g})}{\mathrm{T}-\mathrm{T}_{0}(\mathrm{~g})}
$$

where, $A, B$, and $T_{0}$ are temperature independent material constants. Equation (1) can be reduced to a linear relationship for narrow temperature intervals to form the Arthenius equation:

$$
\ln (\pi)=E(g)+\frac{F(g)}{T}
$$

where $E$ and $F$ are temperature independent material constants. The constants $A, B, T, E$, and $F$ can then be modeled as functions of composition.

The empirical model form is that of a simple first- or second-order mixture model with coefficients for major oxide components:

$$
p=\sum_{i=1}^{a} a_{i} g_{i}+\sum_{i=1}^{n-1} \sum_{j=1}^{a} b_{i j} g_{i} g_{j}
$$

where $p$ is the transformed property (such as $\ln \mathrm{r}_{\mathrm{Na}}$ ), $\mathrm{g}_{1}$ is the $\mathrm{i}$-th component mass fraction, and $\mathrm{a}_{\mathrm{i}}$ and $b_{i j}$ are the first- and second-order model coefficients. A second-order model has a limited number of nonzero $b_{i j}$ 's, whereas all $b_{i j}$ 's are zero in the first-order model. Component effects are given by the slope of $p$ vs. component change curve at a given composition point. This slope 
can be calculated from Equation (3) for a first-order model:

$$
\frac{\partial p}{\partial g_{\alpha}}=\frac{a_{\alpha}-p}{1-g_{\alpha}}
$$

where, $\partial \mathrm{p} / \partial \mathrm{g}_{\alpha}$ is the effect of adding (or subtracting) the $\alpha$-th component on $\mathrm{p}$. The effect of replacing component $\beta$ by component $\alpha$ can also be expressed simply for the first-order model as:

$$
\frac{\partial p}{\partial g_{\alpha}}=a_{\alpha}-a_{\beta} \text {. }
$$

These relationships will be further discussed in this report. A table of properties and their associated coefficients are listed in the summary.

\subsection{Experimental Approach}

A composition envelope approach has been used to characterize the property / composition relationships for Hanford waste glasses. A one-component-at-a-time change study was chosen for the first phase of the higher glass melting temperature CVS because of the large composition range, non-linear component effects, and the number of components which may vary in the waste glass. This study is the first of two steps described in detail in the test plans for each stage (Langowski et al. 1994 and Piepel et al. 1995). The baseline glass (CVS3-1) was formulated from 50 wt\% of Hanford waste blend simulant and additives to allow melting at $1350^{\circ} \mathrm{C}$.

The test matrix in Table II includes glasses varied one-component-at-a-time with the remaining components in the same relative proportion as in the baseline glass (CVS3-1). The components varied are $\mathrm{SiO}_{2}$ (2 to 5), $\mathrm{B}_{2} \mathrm{O}_{3}(6$ and 7$), \mathrm{Na}_{2} \mathrm{O}$ (8 and 9), $\mathrm{Li}_{2} \mathrm{O}$ (10 to 12), $\mathrm{Fe}_{2} \mathrm{O}_{3}$ (13 to 15 and 27), $\mathrm{Al}_{2} \mathrm{O}_{3}$ (16 to 19), $\mathrm{ZO}_{2}$ (20 to 23), Others (24 and 25), $\mathrm{Bi}_{2} \mathrm{O}_{3}$ (28 to 31 ), $\mathrm{UO}_{2}$ (32 to 36), and $\mathrm{P}_{2} \mathrm{O}_{5}\left(37\right.$ to 40 ). As most glasses contain $\mathrm{Nd}_{2} \mathrm{O}_{3}$ as a substitute for $\mathrm{UO}_{2}$, the baseline glass for $\mathrm{UO}_{2}$ change is CVS3-32 with Nd replaced by $\mathrm{U}$ on a nearly one-to-one molar basis.

Additional studies that have varied components one-at-a-time from other baseline glass compositions include:

- $\quad$ HTB651 $-\mathrm{P}_{2} \mathrm{O}_{5}, \mathrm{TiO}_{2}$, and $\mathrm{Cr}_{2} \mathrm{O}_{3}$ (Li et al. 1995),

- $\quad \mathrm{PFP}-\mathrm{P}_{2} \mathrm{O}_{5}$ (Li et al. 1995),

- $\quad \mathrm{HW} 39-4-\mathrm{SiO}_{2}, \mathrm{~B}_{2} \mathrm{O}_{3}, \mathrm{Na}_{2} \mathrm{O}, \mathrm{Li}_{2} \mathrm{O}, \mathrm{CaO}, \mathrm{MgO}$, and $\mathrm{Al}_{2} \mathrm{O}_{3}$ (Hrma, Piepel, et al. 1994), and

- WV205 - $\mathrm{SiO}_{2}, \mathrm{Na}_{2} \mathrm{O}, \mathrm{Li}_{2} \mathrm{O}, \mathrm{Al}_{2} \mathrm{O}_{3}, \mathrm{Fe}_{2} \mathrm{O}_{3}, \mathrm{ZrO}_{2}, \mathrm{TiO}_{2}$, and $\mathrm{Cr}_{2} \mathrm{O}_{3}$ (Feng 1989). 
Table II. HTM test matrix in mass fractions (Langowski et al. 1994).

\begin{tabular}{|c|c|c|c|c|c|c|c|c|c|c|c|}
\hline Glass \# & $1 \mathrm{O}_{2}$ & $\mathrm{~B}_{2} \mathrm{O}_{3}$ & $\mathrm{Na}_{2} \mathrm{O}$ & $\mathrm{L}_{2} \mathrm{O}$ & $e_{2} O_{3}$ & $\mathrm{l}_{2} \mathrm{O}_{3}$ & $2 \mathrm{OO}_{2}$ & $\mathrm{H}_{2} \mathrm{O}_{3}$ & ${ }_{2} \mathrm{O}_{5}$ & $\mathrm{JO}_{2}$ & Others \\
\hline 3.1 & & & 3 & 286 & 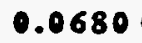 & 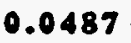 & & & & & 321 \\
\hline $3-2$ & & 0.0004 & 0.1057 & 0.0245 & 0.0583 & 0.0417 & 0375 & 18 & 068 & 0000 & 1133 \\
\hline Cvs3-3 & & 0.0005 & 0.1454 & 0.0337 & .0801 & 0.0574 & 0.0516 & & 0094 & 0.0000 & .1557 \\
\hline CVs3-4 & & 0.0006 & 0.1586 & 0.0367 & 0.0874 & 0.0626 & 0.0563 & 0.0176 & 0.0102 & 0.0000 & 0.1700 \\
\hline Cvs3-5 & 0.3700 & 0.0006 & 0.1665 & 0.0386 & $0: 0918$ & 0.0657 & 0.0591 & 0.0185 & 0.0107 & 0.0000 & 0.1785 \\
\hline CvS3-6 & 0.4889 & $\bullet .0837$ & 0.1131 & 0.0262 & 0.0623 & 0.0446 & 0.0401 & 0.0126 & 0.0073 & 0.0000 & .1212 \\
\hline CVS3-7 & 0.5122 & 0.0400 & 0.1185 & 0.0274 & 0.0653 & 0.0468 & 0.0420 & 0.0132 & 0.0076 & 0.0000 & .1270 \\
\hline CVS3-8 & 0.4710 & 0.0004 & 0.2258 & 0.0252 & 0.0600 & 0.0430 & 0.0387 & 0.0121 & 0.0070 & 0.0000 & .1168 \\
\hline CVS3-9 & 0.5779 & 0.0005 & & 0.0309 & 0.0737 & 27 & 0.0474 & & & & \\
\hline CVs3-10 & 0.5097 & 0.0004 & 0.1179 & 0.0716 & 0.0650 & 0.0465 & 0.0418 & 0.0131 & 76 & & 1264 \\
\hline CVs3-11 & 0.5215 & 0.0005 & 0.1206 & 0.0500 & 0.0665 & 0.0476 & 0.0428 & 0.0134 & & & 1293 \\
\hline CVS3-12 & 0.5490 & 0.0005 & 0.1270 & 0.0000 & 0.0700 & 0.0501 & 0.0451 & & & 0.0000 & 0.1360 \\
\hline CVS3-13 & 0.4864 & 0.0004 & 0.1125 & 0.0260 & 00 & 0.0444 & 0.0399 & 0.0125 & 72 & 0.0000 & .1207 \\
\hline CVS3-14 & 0.5093 & 0.0004 & 0.1178 & 0.0273 & 0.1100 & 0.0465 & 0.0418 & 0.0131 & 0.0076 & 0.0000 & 0.1262 \\
\hline Cvs3-15 & 0.5722 & 0.0005 & 0.1324 & 0.0306 & 0.0000 & 0.0522 & 0.0470 & 0.0147 & 085 & 000 & 0.1419 \\
\hline CVS3-16 & 0.4204 & 0.0004 & 0.0972 & 0.0225 & 0.0536 & 0.2500 & 0.0345 & 0.0108 & 0.0063 & 0.0000 & 0.1043 \\
\hline CVS3-17 & 0.4597 & 0.0004 & 0.1063 & 0.0246 & 0.0586 & 0.1800 & 0.0377 & 0.0118 & 68 & 100 & 0.1141 \\
\hline CVS3-18 & 0.4877 & 0.0004 & 0.1128 & 0.0261 & 0.0622 & & 0.0400 & 0.0126 & 73 & & 0.1209 \\
\hline CVS3-19 & 0.5606 & 0.0005 & 0.1297 & 0.0300 & 0.0 & & 0.0460 & 0.0144 & & & 1389 \\
\hline CVS3-20 & 0.4685 & 0.0004 & 0.1084 & 0.0251 & 0.0597 & 0.0428 & 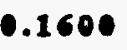 & 0.0 & & & 1160 \\
\hline Cvs3-21 & 0.4908 & 0.0004 & 0.1135 & .0 .0263 & 0.0626 & 0.0 & 20 & 0.0 & & & 1217 \\
\hline CVS3-22 & 0.5131 & 0.0004 & 0.1187 & 0.0275 & 0.0654 & 0.0 & 10 & 0.0132 & & & 1273 \\
\hline Cvs3-23 & 0.5577 & 0.0005 & 0.1290 & 0.0299 & 0.0711 & 0.0509 & 0.0 & 0.0144 & & 00 & 0.1382 \\
\hline CVS3-24 & 0.4966 & 0.0004 & 0.1149 & 0.0266 & 0.0633 & 0.0453 & 0.0408 & 0.0195 & 13 & 0.0000 & 0.1813 \\
\hline Cvs3-25 & 0.5742 & 0.0005 & 0.1328 & 0.0307 & 0.0732 & 0.0524 & 0.0471 & 0.0073 & 0.0042 & 0.0000 & 0.0776 \\
\hline CVS3-26 & 0.5328 & 0.1048 & 0.1129 & 0.0373 & $0.0733^{\circ}$ & 0.0235 & 0.0392 & 0.0000 & 0.0010 & 100 & 0.0752 \\
\hline CVS3-27 & 0.4864 & 0.0004 & 0.1125 & 0.0260 & .1500 & 0.0444 & 0.0399 & 0.0125 & 0.0072 & 100 & .1207 \\
\hline CVS3-28 & 0.5170 & 0.0005 & 0.1196 & 0.0277 & 559 & 0.0472 & 0.0424 & 37 & 77 & 100 & 0.1283 \\
\hline CVS3-29 & 62 & 0.0005 & 0.1171 & 0.0271 & 545 & 0.0462 & 0.0416 & $\bullet .0637$ & 0.0075 & 0.0000 & 0.1256 \\
\hline CvS3-30 & 0.4792 & 0.0005 & 0.1109 & 0.0257 & 1611 & 0.0437 & 0.0393 & 0.1137 & 0.0071 & 0.0 & 0.1188 \\
\hline CVS3-31 & 0.4522 & 0.0004 & 0.1046 & 0.0242 & 0.0576 & 0.0413 & 0.0371 & 0.1637 & 0.0067 & 0.0000 & 0.1122 \\
\hline CVS3-32 & 0.5306 & 0.0004 & 0.1146 & 0.0287 & 0631 & 0.0452 & 0.0407 & $\bullet .0127$ & 00 & $\bullet$ & 0.0616 \\
\hline $\begin{array}{l}\text { CVS3-33 } \\
\text { CVS3-34 }\end{array}$ & $\begin{array}{l}0.5644 \\
0.5475\end{array}$ & $\begin{array}{l}0.0005 \\
0.0004\end{array}$ & $\begin{array}{l}0.1219 \\
0.1182\end{array}$ & $\begin{array}{l}0.0305 \\
0.0296\end{array}$ & $\begin{array}{l}0.0672 \\
0.0652\end{array}$ & $\begin{array}{l}0.0481 \\
0.0467\end{array}$ & $\begin{array}{l}0.0432 \\
0.0420\end{array}$ & $\begin{array}{l}0.0135 \\
0.0131\end{array}$ & $\begin{array}{l}0.0 \\
0.0\end{array}$ & & $\begin{array}{l}0.0690 \\
0.0652\end{array}$ \\
\hline CVS3-35 & 0.5136 & 0.0004 & 0.1109 & 0.0277 & 0.0611 & 0.0438 & 0.0394 & 0.0123 & 0.0 & $\bullet$ & 0.0583 \\
\hline CVS3-36 & 0.4966 & 0.0004 & 0.1072 & 0.0268 & 0.0591 & 0.0423 & 0.0381 & 0.0119 & 0.0 & 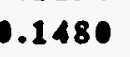 & 0.0550 \\
\hline CVS3-37 & 0.5214 & 0.0005 & 0.1206 & 0.0279 & 0.0665 & 0.0 & 0.0 & 0.0134 & & & .1293 \\
\hline CVs3-38 & 0.5107 & 0.0005 & 0.1 & 0.02 & & & & 31 & & & 0.1266 \\
\hline CVS3-39 & & 0.0005 & 0.1156 & 0.0268 & & 0.0456 & & 0.0129 & & 0.0000 & 0.124 \\
\hline 0 & 92 & 0,0005 & 1132 & 0.0262 & 524 & 0.0447 & 00 & & & & וביו 0 \\
\hline
\end{tabular}


The glasses in Table II were fabricated and tested according to standard test procedures in the Glass Development Laboratory at PNL (Hrma, Piepel, et al. 1994). The following properties and characteristics have been measured and summarized:

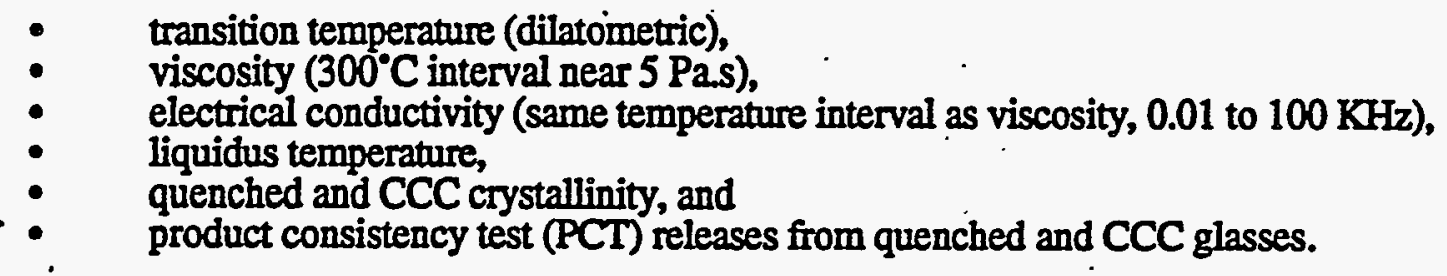

\subsection{Process Related Properties}

The processing related properties of practical significance to waste vitrification are $T_{g}$, viscosity $(\eta)$, electrical conductivity $(\varepsilon)$, and $\mathrm{T}_{L}$. A summary of these properties is given in Table III. The coefficients $A, B$, and $T_{0}$ were obtained by non-linear least squares fitting of the viscosity-temperature data. The second set of $A, B$, and $T_{0}$ values were fit using an additional data point $\left(\eta=10^{11.3} \mathrm{Pas}\right)$ at the glass transition temperature. The $E$ and $F$ coefficients were obtained by a linear regression fit of the Arthenius Equation (2) to the viscosity and electrical conductivity data found in Sections 10.2 and 10.3, respectively. The results for glass melting temperature, viscosity, electrical conductivity, and glass transition temperature are discussed in the following subsections. First- and second-order models have been fitted statistically to this data and are presented in Section 6.0. The response of many process related properties to changing components are nonlinear as figures in this section show. In these cases, nonlinear (second-order) models, found in Table XI, may give better property predictions. 
Table III. Processing related parameters $\left(T_{g}\right.$, VFT $A, B$, and $T_{0}$ for viscosity, Arrhenius $E$ and $F$ for viscosity and electrical conductivity, and $T_{M}$ ).

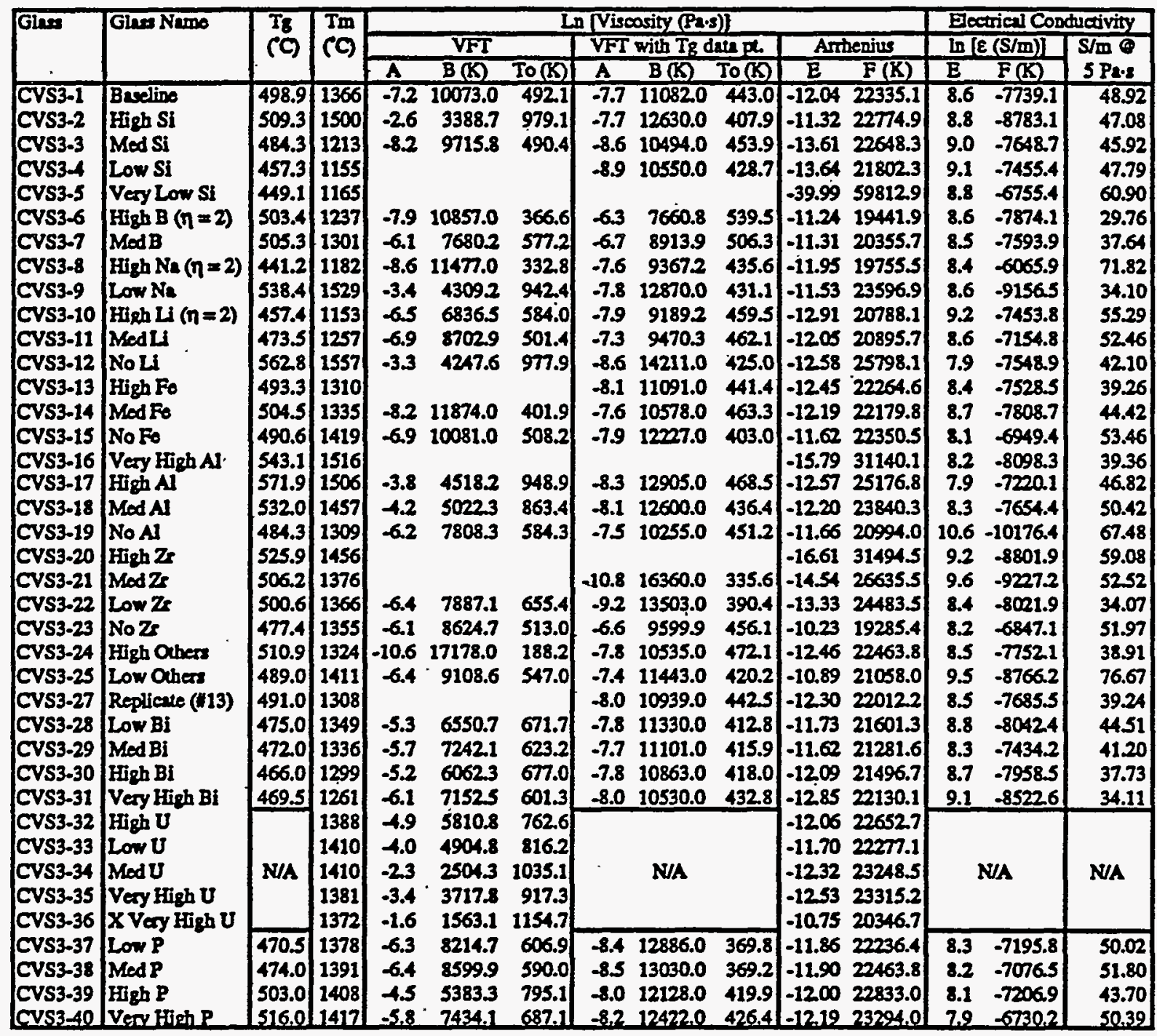

\subsection{Melting Temperature}

Since viscosity is a function of both temperature and composition, the effect of composition can be shown in three ways: 1) effects of components on viscosity at a set temperature, 2) effects of components on temperature at a fixed viscosity, and 3) component effects on the VFT parameters $A, B$, and $T_{0}$. This study has been designed to develop property data for glasses melting over a range of temperatures suitable for processing in a high-temperature melter. Hence, option one is not considered.

The effect of components on the $T_{M}$ of the glass, where $T_{M}$ is the temperature at a viscosity of $5 \mathrm{~Pa} \cdot \mathrm{S}$, can be seen in Figure 1. Table IV shows the slopes of $\mathrm{T}_{M}$ versus component mass fractions (component effects). A first-order model has been fitted to the CVS $T_{M}$ data (including 
low and high temperature phases). The model coefficients (at from Equation (3)) are compared to those calculated from CVS3-1 measured effects using Equation (4) and are listed in Table V.

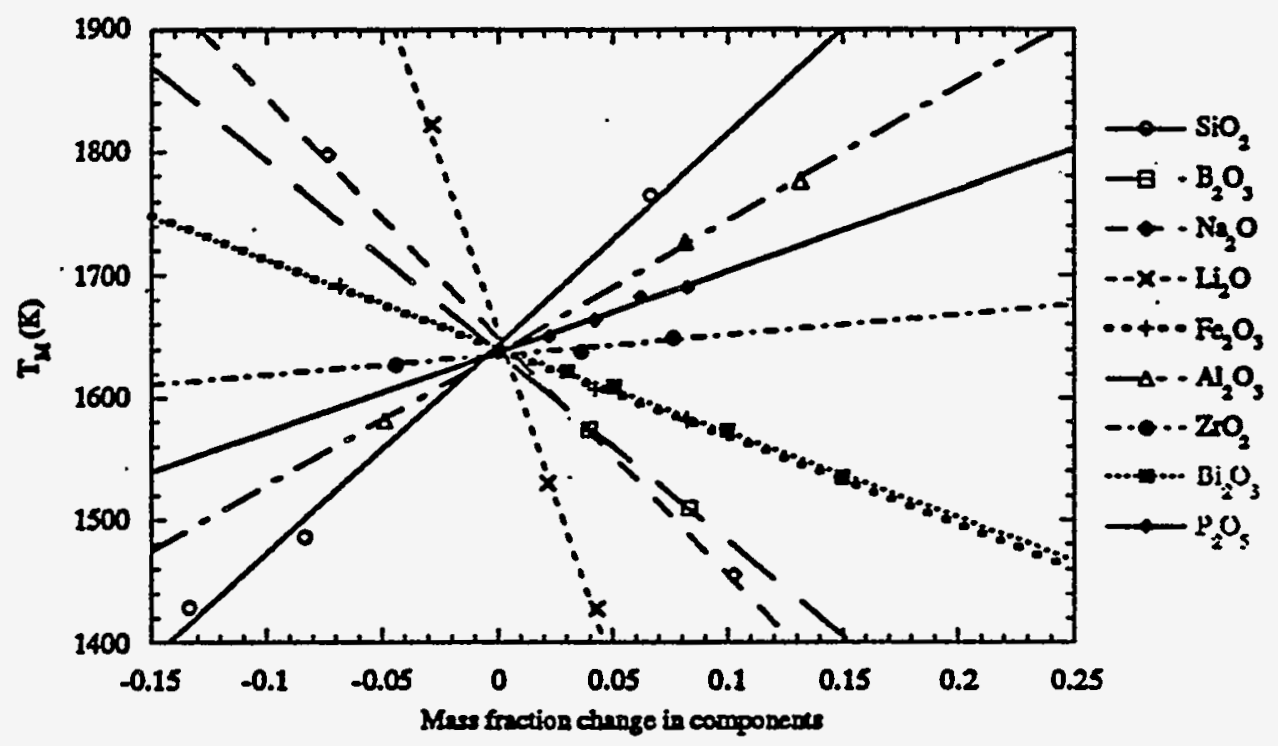

Figure 1. Effects of components on $T_{M}$ for CVS3-1 baseline glass.

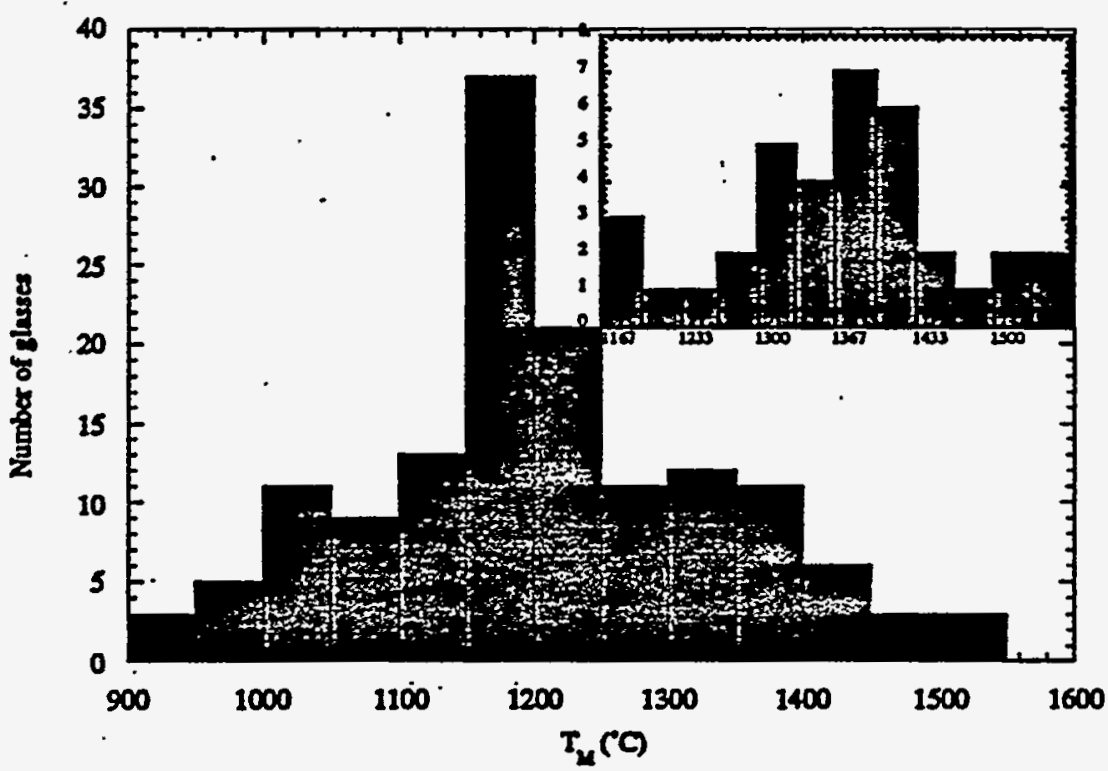

Figure 2. Histogram of measured $T_{M}$ for CVS-I, -II, and -III glasses. CVS-III glasses are shown in the insert.

Figure 2 shows the histogram of melting temperatures for the combined CVS study, showing that a TM range from 900 to $1540^{\circ} \mathrm{C}$ has been covered. The CVS-I and -II glasses alone range from 900 to $1450^{\circ} \mathrm{C}$, although a majority of low-temperature glasses melt below $1250^{\circ} \mathrm{C}$. A histogram 
of $T_{M}$ shows that the CVS-III data covers the temperature region from 1140 to $1540^{\circ} \mathrm{C}$ (see insert in Figure 2) with a maximum number of glasses near $1350^{\circ} \mathrm{C}$ (the $T_{M}$ of the baseline glass). By comparison, the low temperature phases of the CVS-I and -II were designed around $1150^{\circ} \mathrm{C}$.

Table IV. Component effects on processing parameters measured at the CVS3-1 composition.

\begin{tabular}{|c|c|c|c|c|c|c|c|c|c|c|c|}
\hline Effect & $\mathrm{SiO}_{2}$ & $\mathrm{~B}_{2} \mathrm{O}_{3}$ & $\mathrm{Na}_{2} \mathrm{O}$ & $\mathrm{Li}_{2} \mathrm{O}$ & $\mathrm{Fe}_{2} \mathrm{O}_{3}$ & $\overline{\mathrm{Al}_{2} \mathrm{O}_{3}}$ & $\mathrm{ZrO}_{2}$ & $\mathrm{Bi}_{2} \mathrm{O}_{3}$ & $\mathrm{P}_{2} \mathrm{O}_{5}$ & $\mathrm{UO}_{2}$ & Others \\
\hline $\mathrm{T}_{\mathrm{M}}(\mathrm{K})$ & 1,916 & $-1,546$ & $-1,964$ & $-5,620$ & -727 & 1,100 & 164 & .710 & 642 & -344 & -698 \\
\hline$F_{\eta}\left(10^{3} \mathrm{~K}\right)$ & 2.1 & .63 .9 & -20.5 & -88.3 & -7.9 & 11.1 & 60.3 & -26.2 & 2.5 & -12.7 & 10.3 \\
\hline$\dot{\varepsilon}_{M}(S / m)$ & 21 & -335 & 211 & 200 & -90 & -128 & -121 & -154 & -28 & & -289 \\
\hline $\mathrm{F}_{\varepsilon}\left(10^{3} \mathrm{~K}\right)$ & -7.8 & 8.5 & 18.1 & 3.6 & -5.6 & -1.0 & -19.0 & -4.8 & 15.1 & & 7.3 \\
\hline $\mathrm{T}_{\mathrm{g}}(\mathrm{K})$ & 174 & 260 & -549 & $-1,696$ & 46 & 314 & 265 & -658 & 209 & & 178 \\
\hline
\end{tabular}

The $T_{M}$ range for CVS-III being 1140 to $1540^{\circ} \mathrm{C}$ (Figure 2), an addition of any component with a coefficient $\leq 1140$ or $\geq 1540^{\circ} \mathrm{C}$ is likely to decrease or increase $T_{M}$, respectively. As Table $V$ shows, components that increase $\mathrm{T}_{M}$ are, $\mathrm{Al}_{2} \mathrm{O}_{3}, \mathrm{SiO}_{2}$, and $\mathrm{P}_{2} \mathrm{O}_{5} ; \mathrm{T}_{M}$ is decreased by $\mathrm{Li}_{2} \mathrm{O}$, $\mathrm{Na}_{2} \mathrm{O}, \mathrm{B}_{2} \mathrm{O}_{3}, \mathrm{Bi}_{2} \mathrm{O}_{3}, \mathrm{Fe}_{2} \mathrm{O}_{3}$, and Others; $\mathrm{UO}_{2}$ and $\mathrm{ZrO} \mathrm{O}_{2}$ can either increase or decrease $\mathrm{T}_{M}$ depending upon the glass composition. The $T_{M}$ range for CVS-I and -II is 900 to $1450^{\circ} \mathrm{C}$. Components that increase $\mathrm{T}_{M}$ of these glasses are $\mathrm{Al}_{2} \mathrm{O}_{3}, \mathrm{SiO}_{2}$, and $\mathrm{ZrO}_{2} ; \mathrm{T}_{\mathrm{M}}$ is decreased by $\mathrm{Li}_{2} \mathrm{O}, \mathrm{Na}_{2} \mathrm{O}, \mathrm{CaO} ; \mathrm{B}_{2} \mathrm{O}_{3}$, and $\mathrm{MgO} ; \mathrm{Fe}_{2} \mathrm{O}_{3}$ and Others can either increase or decrease $\mathrm{T}_{\mathrm{M}}$ depending upon the glass composition.

Many glass components effect $T_{M}$ of high-temperature (CVS-III) and low-temperature (CVS-I and -II) glasses in a similar manner. The CVS-I and -II coefficients for $\mathrm{SiO}_{2}$ and $\mathrm{Al}_{2} \mathrm{O}_{3}$ are virtually identical with those for CVS3-1. Coefficients of the components that tend to decrease $\mathrm{T}_{\mathrm{M}}\left(\mathrm{Li}_{2} \mathrm{O}, \mathrm{Na}_{2} \mathrm{O}\right.$, and $\left.\mathrm{B}_{2} \mathrm{O}_{3}\right)$ have somewhat lower values (stronger effects) in high-temperature glasses. For $\mathrm{B}_{2} \mathrm{O}_{3}$, this may have resulted from lower concentrations of $\mathrm{B}_{2} \mathrm{O}_{3}$ in high-temperature glasses in conjunction with boron's nonlinear effect on glass viscosity. Small additions of $\mathrm{Li}_{2} \mathrm{O}$, $\mathrm{Na}_{2} \mathrm{O}$ and $\mathrm{B}_{2} \mathrm{O}_{3}$ may be used to lower $\mathrm{T}_{M}$ when desirable (see further discussion in Section 4.6). The coefficient for $\mathrm{Fe}_{2} \mathrm{O}_{3}$ is substantially lower in high-temperature glasses, probably because of a higher Fell/Fe ratio (this has not been confirmed experimentally). As reported by Li et al. (1995), $\mathrm{T}_{M}$ is also decreased by $\mathrm{TiO}_{2}$ (not included in Tables $\mathrm{IV}$ and $\mathrm{V}$ ). 


\section{PVTD-C95-02.01E/J}

Table V. First-order model coefficients for the melting temperature, VFT viscosity parameters, Arrhenius viscosity and electrical conductivity parameters (determined from CVS3-1 data and models fit to CVS-I and -II data) and electrical conductivity at melting temperature (determined from CVS3-1 data).

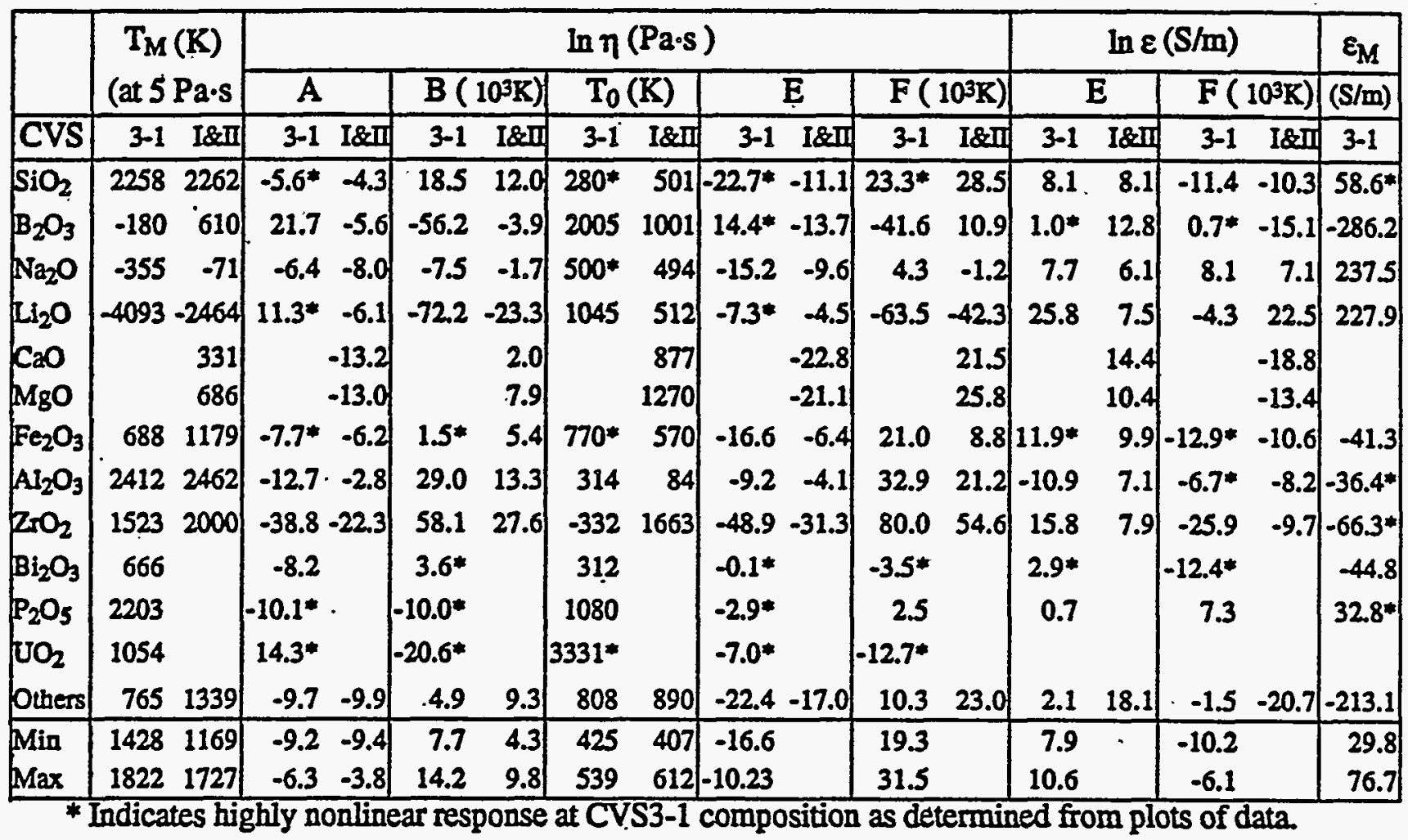

\subsection{Vogel - Fulcher - Tammann Relationship}

It is valuable to consider the effects of composition on the VFT parameters ( $A, B$, and $\left.T_{0}\right)$ for understanding of viscosity at any temperature. The first-order coefficients in Table $V$ were obtained by fitting first-order models (Equation (3)) to the A, B, and $T_{0}$ values from Table III (these values were obtained using $T_{8}$ data along with measured viscosity values except for glasses containing $\mathrm{UO}_{2}$ ). These VFT models will be used to:

- formulate optimum glass compositions,

- assess the effects of temperature on melter operation for a given composition,

- estimate effects of composition fluctuations on melter operation, and

- $\quad$ provide means of mitigating operational problems through feed trimming.

The effect of composition on viscosity was described in depth for low temperature glasses by Hrma et al. (1994 and 1995). Note that the first-order coefficients for high-temperature glasses in Table V are strictly valid for the CVS3-1 composition neighborhood. The CVS-I and -II coefficients are averaged over the composition range of low temperature CVS glasses.

The $T_{0}$ and $A$ parameters represent extreme values: $T_{0}$ is the temperature at which $\eta \rightarrow \infty$ 
and $A$ is the $\ln \eta$ value at $T \rightarrow \infty$. The experimental data are confined to a narrow range of viscosity and temperature and hence the $T_{0}$ and $A$ values are subject to a large uncertainty, which is only partially reduced by using an additional high viscosity data point at $\mathrm{T}_{\mathrm{g}}$. The composition dependence of $A$ is generally weak. It has been suggested that $A$ be taken as a composition independent constant for waste glasses (Hrma et al. 1995).

In the case of the B parameter, its coefficient values for the CVS3-1 glass roughly parallel the averaged $B$ coefficients for low temperature glasses (CVS-I and -I) and also parallel the glass length $F_{\eta}$ coefficients determined by fitting the Arrhenius equation to the viscosity data (Section 4.4). $\mathrm{ZrO} 2$ most increases and $\mathrm{Li}_{2} \mathrm{O}$ most decreases $\mathrm{B} . \mathrm{Al}_{2} \mathrm{O}_{3}$ and $\mathrm{SiO}_{2}$ also increase $\mathrm{B}$, whereas $\mathrm{Na}_{2} \mathrm{O}$ decreases it. $\mathrm{Fe}_{2} \mathrm{O}_{3}$ has little effect on $\mathrm{B}$. $\mathrm{B}_{2} \mathrm{O}_{3}$ decreases $\mathrm{B}$ significantly more in CVS3-1 glass than in the low temperature glasses.

\subsection{Electrical Conductivity}

Like viscosity, electrical conductivity is a function of both temperature and composition. For practical purposes, the effect of composition on the electrical conductivity of glass at the melting temperature $\left(\varepsilon_{\mathrm{M}}\right)$ is considered. The component effects shown in Table IV and Figure 3 and component coefficients shown in Table $\mathrm{V}$ confirm that electrical conductivity is increased only by alkaline oxides, i.e., $\mathrm{Na}_{2} \mathrm{O}$ and $\mathrm{Li}_{2} \mathrm{O}$ (Hrma et al. 1995). $\mathrm{SiO}_{2}$ and $\mathrm{P}_{2} \mathrm{O}_{5}$ have little effect. All other components tend to decrease electrical conductivity.

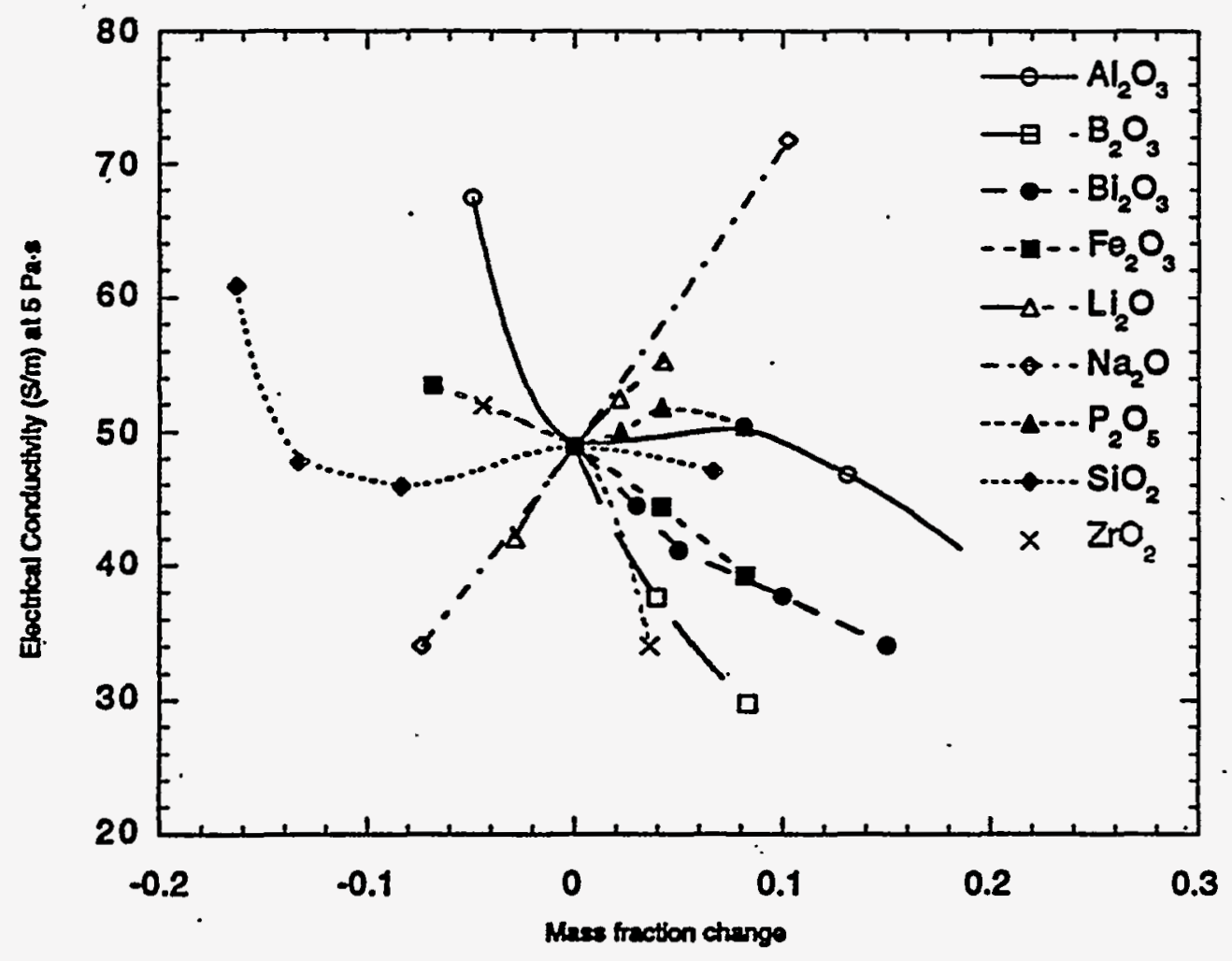

Figure 3 Component effects on electrical conductivity at melting temperature. 


\subsection{Length}

The component effects for activation energy in the Arhenius equation (Equation (2)) express the effect of components on the response of the glass to changing temperature, i.e., the viscous $\left(F_{n}\right)$ or electrical $\left(F_{2}\right)$ "length" of glass. According to Table IV, the component that "shortens." CVS3-1 glass most with respect to viscosity is $\mathrm{ZrO}_{2}$; that which most "lengthens" it is $\mathrm{Li}_{2} \mathrm{O}$. These and the effects of other components on the viscous length are consistent with the effects on VFT B component coefficients.discissed in Section 4.2. The electrical conductivity dependence of CVS3-1 glass on temperature is lengthened most by $\mathrm{Na}_{2} \mathrm{O}$ followed by $\mathrm{P}_{2} \mathrm{O}_{5}$ (Table IV). The differences between CVS3-1 glass component coefficients and those of the CVS-I and II are evident from Table V. Except for $\mathrm{B}_{2} \mathrm{O}_{3}, \mathrm{Li}_{2} \mathrm{O}$ and $\mathrm{ZiO}$, the values of coefficients are similar.

\subsection{Glass Transition Temperature}

Figure 4 shows the effect of components on $\mathrm{T}_{8}$. when varied one component at a time from the CVS3-1 glass. It can be seen by this plot that $\mathrm{T}_{8}$ is lowered by the alkaline oxides $\left(\mathrm{Li}_{2} \mathrm{O}\right.$ and $\mathrm{Na}_{2} \mathrm{O}$ ) and $\mathrm{Bi}_{2} \mathrm{O}_{3}$, while raised by $\mathrm{Al}_{2} \mathrm{O}_{3}, \mathrm{ZNO}_{2}, \mathrm{~B}_{2} \mathrm{O}_{3}, \mathrm{Fe}_{2} \mathrm{O}_{3}$ and $\mathrm{SiO}_{2}$. The effect of $\mathrm{P}_{2} \mathrm{O}_{5}$ on $\mathrm{T}_{8}$ is anomalous. Small additions ( 2 wt $\%$ ) of $\mathrm{P}_{2} \mathrm{O}_{5}$ decrease $\mathrm{T}_{8}$ as much as equivalent additions of $\mathrm{Li}_{2} \mathrm{O}$ and $\mathrm{Bi}_{2} \mathrm{O}_{3}$. Additions larger than $5 \mathrm{wt} \%$ have an increasing effect on $\mathrm{T}_{8}$. This behavior may be related to crystallization of phosphates (see Table VIII). The numerical values of component . effects, evaluated as the first derivatives of $T_{B}$ with respect to mass fraction change at the baseline composition, are reported in Table IV. Similar relative component effects are seen in low temperature glasses as evident by the average low temperature component coefficients.

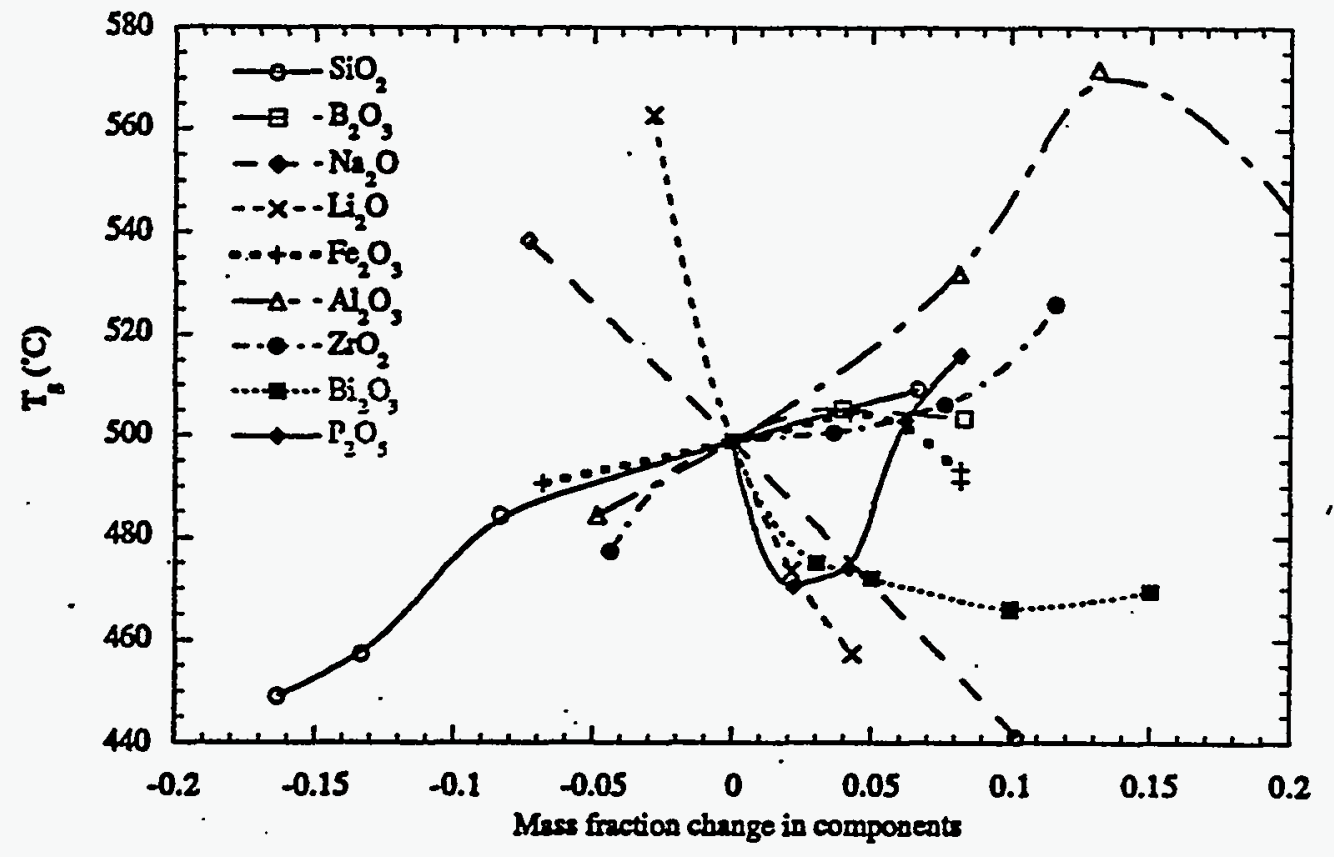

Figure 4. Component effects on $T_{g}$. 
It is interesting to compare the difference in components effects on $T_{g}$ to those on $T_{M}$ (Table.IV) since $T_{g}$ and $T_{M}$ represent the temperature at a constant viscosity, 1011.3 and $5 \mathrm{Pas}$, respectively. Both temperatures are decreased most by $\mathrm{Li}_{2} \mathrm{O}$ and also by $\mathrm{Bi}_{2} \mathrm{O}_{3}$ and $\mathrm{Na}_{2} \mathrm{O}$. The $T_{M}$ is increased most by $\mathrm{SiO}_{2}, \mathrm{Al}_{2} \mathrm{O}_{3}$, and $\mathrm{P}_{2} \mathrm{O}_{5}$, while $\mathrm{T}_{8}$ is increased most by $\mathrm{Al}_{2} \mathrm{O}_{3}, \mathrm{ZO}$, and $\mathrm{P}_{2} \mathrm{O}_{5}$. $\mathrm{SiO}_{2}$ has a much stronger effect on $\mathrm{T}_{M}$ than $\mathrm{T}_{8}$. The effect of $\mathrm{B}_{2} \mathrm{O}_{3}$ and $\mathrm{Fe}_{2} \mathrm{O}_{3}$ are opposite for $T_{M}$ and $T_{g}$.

\subsection{Liquidus Temperature}

Glass can crystallize at $\mathrm{T}<\mathrm{T}_{\mathrm{L}}$. Crystalline phases, if precipitated in some types of melters, such as a continuous melter with a flat bottom, can cause sludge formation on the melter bottom or even melter electrode shorting if the phases are highly conductive. For these reasons, restrictions have been placed on glass to avoid precipitation and sludge formation in the melter. Since this behavior is difficult to predict, restrictions on composition must be conservative to avoid the problematic events. To better predict $T_{L}$ of glass, a fundamental understanding of the phenomena and composition effects must be gained.

The $T_{L}$ 's of CVS III glasses are listed in Section 10.4. The effects of components on the .T of CVS3-1 glass are shown in Figure 5 and summarized in Table VI.

Table VI. Effect of components on $T_{L}, T_{M}$, and $T_{M}-T_{L}$ of CVS3-1 glass.

\begin{tabular}{|l|c|c|c|c|c|c|c|c|c|c|}
\hline Effect & $\mathrm{SiO}_{2}$ & $\mathrm{~B}_{2} \mathrm{O}_{3}$ & $\mathrm{Na}_{2} \mathrm{O}$ & $\mathrm{Li}_{2} \mathrm{O}$ & $\mathrm{Fe}_{2} \mathrm{O}_{3}$ & $\mathrm{Al}_{2} \mathrm{O}_{3}$ & $\mathrm{ZO}_{2}$ & $\mathrm{Bi}_{2} \mathrm{O}_{3}$ & $\mathrm{P}_{2} \mathrm{O}_{5}$ & Others \\
\hline $\mathrm{T}_{\mathrm{L}}(\mathrm{K})$ & 337 & -305 & $-2,094$ & $-3,609$ & 1,663 & 1,699 & 688 & -289 & 708 & 556 \\
\hline $\mathrm{T}_{M}(\mathrm{~K})$ & 1,916 & $-1,546$ & $-1,964$ & $-5,620$ & -727 & 1,100 & 164 & -710 & 642 & -698 \\
\hline $\mathrm{T}_{M}-\mathrm{T}_{\mathrm{L}}(\mathrm{K})$ & 1,584 & -761 & 48 & $-2,011$ & $-2,099$ & -599 & -544 & -421 & -67 & $-1,474$ \\
\hline
\end{tabular}




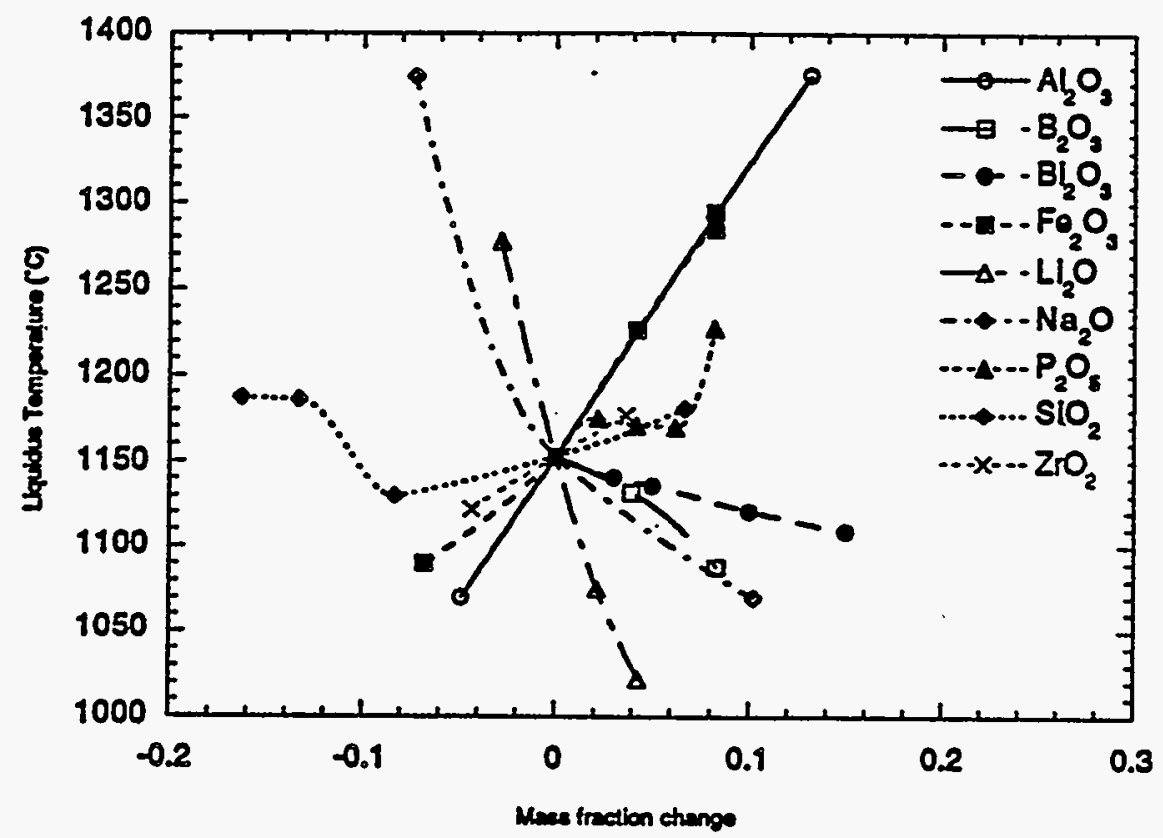

Figure 5. Component effects on $T_{L}$.

As Figure 5 shows, the effects of most components on $T_{L}$ are linear. The deviation from linearity seen in $\mathrm{SiO}_{2}$ and $\mathrm{P}_{2} \mathrm{O}_{5}$ effects is caused by a change in the primary phase of crystallization. For a majority of the CVS-III glasses, spinel was the primary phase, see Section 10.4. For low. $\mathrm{SiO}_{2}$ glasses, the primary phase is neodymium-cerium-zirconate. The highest $\mathrm{P}_{2} \mathrm{O}_{5}$ glass has a primary phase of rare earth (Nd, $\mathrm{La}$, and $\mathrm{Ce}$ ) zirconate. For eight glasses, $\mathrm{T}_{\mathrm{L}}$ was not obtained. Five of these glasses contain $\mathrm{UO}_{2}$ (CVS3-32 to -36) and the remaining three contain 25 and $18 \mathrm{wt} \% \mathrm{Al}_{2} \mathrm{O}_{3}$ and $16 \mathrm{wt} \% \mathrm{ZrO}_{2}$ (CVS3-16, -17, and -20).

The $\mathrm{T}_{\mathrm{L}}$ of CVS3-1 glass with a spinel primary phase is increased most by $\mathrm{Fe}_{2} \mathrm{O}_{3}$ and $\mathrm{Al}_{2} \mathrm{O}_{3}$, followed by $\mathrm{P}_{2} \mathrm{O}_{5}, \mathrm{ZrO}_{2}$, Others and $\mathrm{SiO}_{2}$. It is most decreased by $\mathrm{Li}_{2} \mathrm{O}$ and $\mathrm{Na}_{2} \mathrm{O}$, followed by $\mathrm{B}_{2} \mathrm{O}_{3}$ and $\mathrm{Bi}_{2} \mathrm{O}_{3}$.

Examining the effect of each component on the difference between $T_{M}$ and $T_{L}$ (Table VI) shows that addition of $\mathrm{SiO}_{2}$ most effectively increases the gap between melting and liquidus temperatures. This follows from the ability of $\mathrm{SiO}_{2}$ to increase the glass forming tendency. This positive effect of $\mathrm{SiO}_{2}$ on $\mathrm{T}_{\mathrm{M}}-\mathrm{T}_{\mathrm{L}}$ elucidates the empirical observation that high-temperature $\mathrm{HLW}$ glasses generally allow a higher waste loading compared to low-temperature glasses (as a rule, $\mathrm{SiO}_{2}$ is the only additive needed in high-temperature $\mathrm{HLW}$ glasses). $\mathrm{Na}_{2} \mathrm{O}$ has little effect on $\mathrm{T}_{M}$ $T_{L}$ whereas additions of $\mathrm{Li}_{2} \mathrm{O}$ and $\mathrm{B}_{2} \mathrm{O}_{3}$ decrease $T_{M}-T_{L}$. If $T_{M}$ must be reduced, it is therefore advantageous to use $\mathrm{Na}_{2} \mathrm{O}$ as a viscosity reducing additive rather than $\mathrm{Li}_{2} \mathrm{O}$ or $\mathrm{B}_{2} \mathrm{O}_{3}$. This agrees with the conclusions of Kim et al. (1994). $T_{M}-T_{L}$ is strongly decreased by adding refractory oxides $\left(\mathrm{Fe}_{2} \mathrm{O}_{3}, \mathrm{Al}_{2} \mathrm{O}_{3}\right.$, and $\mathrm{ZrO}$ ) and by Others which contain crystal forming components $\mathrm{NiO}$, $\mathrm{Cr}_{2} \mathrm{O}_{3}$ and $\mathrm{CeO}_{2}$. 
Table VII. First-order model coefficients for spinel liquidus temperature.

\begin{tabular}{|l|c|c|c|c|c|c|c|c|c|c|c|c|}
\hline Coefficient (K) & $\mathrm{SiO}_{2} \cdot$ & $\mathrm{B}_{2} \mathrm{O}_{3}$ & $\mathrm{Na}_{2} \mathrm{O}$ & $\mathrm{Li}_{2} \mathrm{O}$ & $\mathrm{CaO}$ & $\mathrm{MgO}_{2}$ & $\mathrm{Fe}_{2} \mathrm{O}_{3}$ & $\mathrm{Al}_{2} \mathrm{O}_{3}$ & $\mathrm{ZrO}_{2}$ & $\mathrm{Bi}_{2} \mathrm{O}_{3}$ & $\mathrm{P}_{2} \mathrm{O}_{5}$ & Others \\
\hline CVS3-1 & 1,282 & 1,121 & -409 & $-2,080$ & & & 2,976 & 3,042 & 2,084 & 1,141 & 2,128 & 1,905 \\
\hline CVS-I and -II & 1,262 & 939 & 277 & 144 & 1,639 & 3,103 & 2,529 & 2,008 & 1,201 & & & 1,278 \\
\hline
\end{tabular}

First-order model coefficients of spinel $T_{L}$, presented for CVS3-1 glass and for CVS-I and -II glasses in Table VII, show a good agreement between low- and high-temperature glasses. $\mathrm{Na}_{2} \mathrm{O}$ and $\mathrm{Li}_{2} \mathrm{O}$ decrease $\mathrm{T}_{\mathrm{L}}$ more strongly in high-than in low-temperature glasses. The refractory oxides also seem to exhibit somewhat stronger effects.

\subsection{Product Characterization}

Results from PCT testing of the CVS-III glasses are given in Section 10.5. For borosilicate glasses, the normalized boron release is commonly used as the indication of network dissolution by PCT because $\mathrm{B}_{2} \mathrm{O}_{3}$ is a glass forming oxide (in alkali containing glasses) and once in solution, it doesn't precipitate in secondary phases. However, $\mathrm{B}_{2} \mathrm{O}_{3}$ concentrations in hightemperature HLW glasses can be very low, thus giving small releases subjected to large measurement errors. Since this is true for a majority of glasses in this study, sodium release was used instead of boron release as a glass durability measure in this report. $\mathrm{Na}_{2} \mathrm{O}$ is present in large concentrations in all Hanford HLW glasses. As CVS-I and -II data show, Na and B normalized releases are generally close to each other (Hrma, Piepel et al. 1994). Although $\mathrm{Na}$ + is subjected to initial ion exchange between glass and water and can participate in secondary reactions, these effects are generally small.

Table VIII. Component effects on $\ln \mathrm{r}_{\mathrm{Na}}$.

\begin{tabular}{|c|c|c|c|c|c|c|}
\hline \multicolumn{7}{|c|}{ CVS3-1 HW39-4 WV205 HTB65T } \\
\hline \multicolumn{7}{|c|}{-11.75} \\
\hline $\mathrm{B}_{2} \mathrm{O}_{3}$ & -9.48 & 10.47 & & & & 9.9 \\
\hline $\mathrm{Na} 2 \mathrm{O}$ & 27.23 & 32.52 & $5.76^{*}$ & & & 21.2 \\
\hline $\begin{array}{l}\mathrm{LiO}_{\mathrm{i}} \\
\mathrm{C}_{20}\end{array}$ & 12.20 & $\begin{array}{l}42.00 \\
16.33\end{array}$ & $5.78^{*}$ & & & $\begin{array}{l}19.27 \\
-2.49\end{array}$ \\
\hline $\mathrm{MgO}$ & & 42.10 & & & & 11.40 \\
\hline $\mathrm{Fe}_{2} \mathrm{O}$ & -4.11 & & 18.01 & & & -4. \\
\hline Alos & -17.34 & -42.95 & -14.23 & & & -26.5 \\
\hline $\mathrm{Z}^{\mathrm{NO}}$ & -7.79 & & -8.85 & & & -12.42 \\
\hline $\begin{array}{lll}\mathrm{P}_{2} \mathrm{O}_{3} \\
\text {. }\end{array}$ & $\begin{array}{r}0.42 \\
-5.91\end{array}$ & & & -11.21 & -12.44 & \\
\hline $\mathrm{UO}_{2}$ & -0.73 & & & & & \\
\hline $\mathrm{Cr}_{2} \mathrm{O}_{3}$ & & & 17.12 & 11.3 & & \\
\hline $\begin{array}{l}\mathrm{TiO}_{2} \\
\text { Others }\end{array}$ & -0.97 & & 1.89 & -5 & & -1.26 \\
\hline
\end{tabular}

* WV205 with $3 \mathrm{wt}_{\mathrm{W}} \mathrm{Al}_{2} \mathrm{O}_{3}$ addition was used as baseline for alkaline oxides.

The component effects taken as slopes of component change versus $\ln \mathrm{T}_{\mathrm{Na}}$ at the zero change point (CVS3-1 glass) are listed in Table VI. These effects are compared for different baseline glasses and composition regions: HW39-4 (Hrma, Piepel et al. 1994), WV205 (Feng et 
al. 1989), HTB651 (Li et al. 1995), PFP (Li et al. 1995), and CVS-I and -II region (taken at the HW39-4 composition).

In Table VIII, CVS3-1 and HTB651 are high-temperature glasses while all others melt at $1150^{\circ} \mathrm{C}$. Component effects for high- and low-temperature glasses show similar trends except for $\mathrm{B}_{2} \mathrm{O}_{3}$, which increases $\mathrm{I}_{\mathrm{Na}}$ (decreases durability) in low-temperature glasses and decreases $\mathrm{I}_{\mathrm{Na}}$ (increases durability) in high-temperature glasses. The magnitude of $\mathrm{SiO}_{2}$ effect is lower in the high-temperature CVS3-1 glass than in low-temperature glasses.

Comparing CVS-I and -II and HW39-4 component effects shows significant differences between averaged and local values for $\mathrm{Li}_{2} \mathrm{O}, \mathrm{CaO}$ and $\mathrm{MgO}$. $\mathrm{Li}_{2} \mathrm{O}$ has definitely a much stronger effect on the HW39-4 glass (see Section 5.3) compared to the average low temperature effect (Hrma, Piepel, et al. 1994). The effect of $\mathrm{CaO}$ is taken from one data point at $1.17 \mathrm{wt} \%$ addition and thus is subject to experimental uncertainty. The difference in the effect of $\mathrm{MgO}$ is considered real-see discussion in Hrma, Piepel, et al. (1994).

The beneficial effect of $\mathrm{P}_{2} \mathrm{O}_{5}$ on CVS3-1 glass durability is comparable to that obtained for HTB651 and PFP glasses. Two more component effects are shown in Table VIII from the HTB651 series: $\mathrm{Cr}_{2} \mathrm{O}_{3}$ and $\mathrm{TiO}_{2}, \mathrm{Cr}_{2} \mathrm{O}_{3}$ substantially increases sodium release (decreases durability) as confirmed by WV205 series and low-level waste glass data ( $\mathrm{Li}$ 1995). However, this effect has low practical consequence because of the low $\mathrm{Cr}_{2} \mathrm{O}_{3}$ solubility in waste glasses. $\mathrm{TiO}_{2}$ decreases sodium release (increases durability) but to a lesser extent than $\mathrm{Al}_{2} \mathrm{O}_{3}$ and $\mathrm{ZrO}_{2}$. Positive effect of $\mathrm{TiO}_{2}$ on glass durability of high-sodium glasses which is weaker than the effect of $\mathrm{Al}_{2} \mathrm{O}_{3}$ was shown in a literature review by $\mathrm{Kim}$ and $\mathrm{Hrma}$ (1995).

Components effects obtained from Feng's (1989) data for WV205 glass are also shown in Table VIII. The effects of $\mathrm{Al}_{2} \mathrm{O}_{3}, \mathrm{ZrO}_{2}$ and $\mathrm{Cr}_{2} \mathrm{O}_{3}$ are in reasonable agreement with the values for other glasses. The effects of $\mathrm{Fe}_{2} \mathrm{O}_{3}$ and $\mathrm{TiO}_{2}$ were based on one and two data points, respectively, in addition to the baseline glass. These effects are probably subjected to experimental error. Additionally, it is not clear from Feng's paper whether the $\mathrm{Fe}_{2} \mathrm{O}_{3}$ enriched glass was prepared under the same redox conditions as the baseline glass.

\section{$5.1 \mathrm{SiO}_{2}$}

The effect of silica on glass durability is positive. As a strongly-bonded network former, $\mathrm{SiO}_{2}$ increases glass network connectivity. A decrease in $\mathrm{I}_{\mathrm{Na}}$ with increasing $\mathrm{SiO}_{2}$ concentration is seen in Figure 6. The effect of $\mathrm{SiO}_{2}$ on in $\mathrm{I}_{\mathrm{Na}}$ as measured at CVS3-1 is -4.45 which is lower than that measured at WV205 $(-6.08)$ and HW39-4 (-11.75) compositions. The difference in effects between the high-temperature glass (CVS3-1) and the low-temperature glass (HW39-4) is remarkable: $\mathrm{SiO}_{2}$ addition effect the low-temperature glass more strongly. Both glasses have the same mass fractions of $\mathrm{SiO}_{2}(0.533)$ and $\mathrm{Na}_{2} \mathrm{O}+\mathrm{Li}_{2} \mathrm{O}(0.150)$ and similar content of $\mathrm{Fe}_{2} \mathrm{O}_{3}$ and $\mathrm{ZrO}_{2}$. They differ in concentrations of $\mathrm{B}_{2} \mathrm{O}_{3}(0.0005$ for CVS3-1 and 0.105 for $\mathrm{HW} 39-4)$ and $\mathrm{Al}_{2} \mathrm{O}_{3}$ (0.049 for CVS3-1 and 0.024 for HW39-4). These differences in composition result in higher durability and viscosity of the high-temperature glass. Whether these composition differences cause the difference in $\mathrm{SiO}_{2}$ effect on PCT release is unclear. The effect of $\mathrm{CCC}$ is not seen in either glass until a very low $\mathrm{SiO}_{2}$ concentration where crystallization has degraded glass durability. 


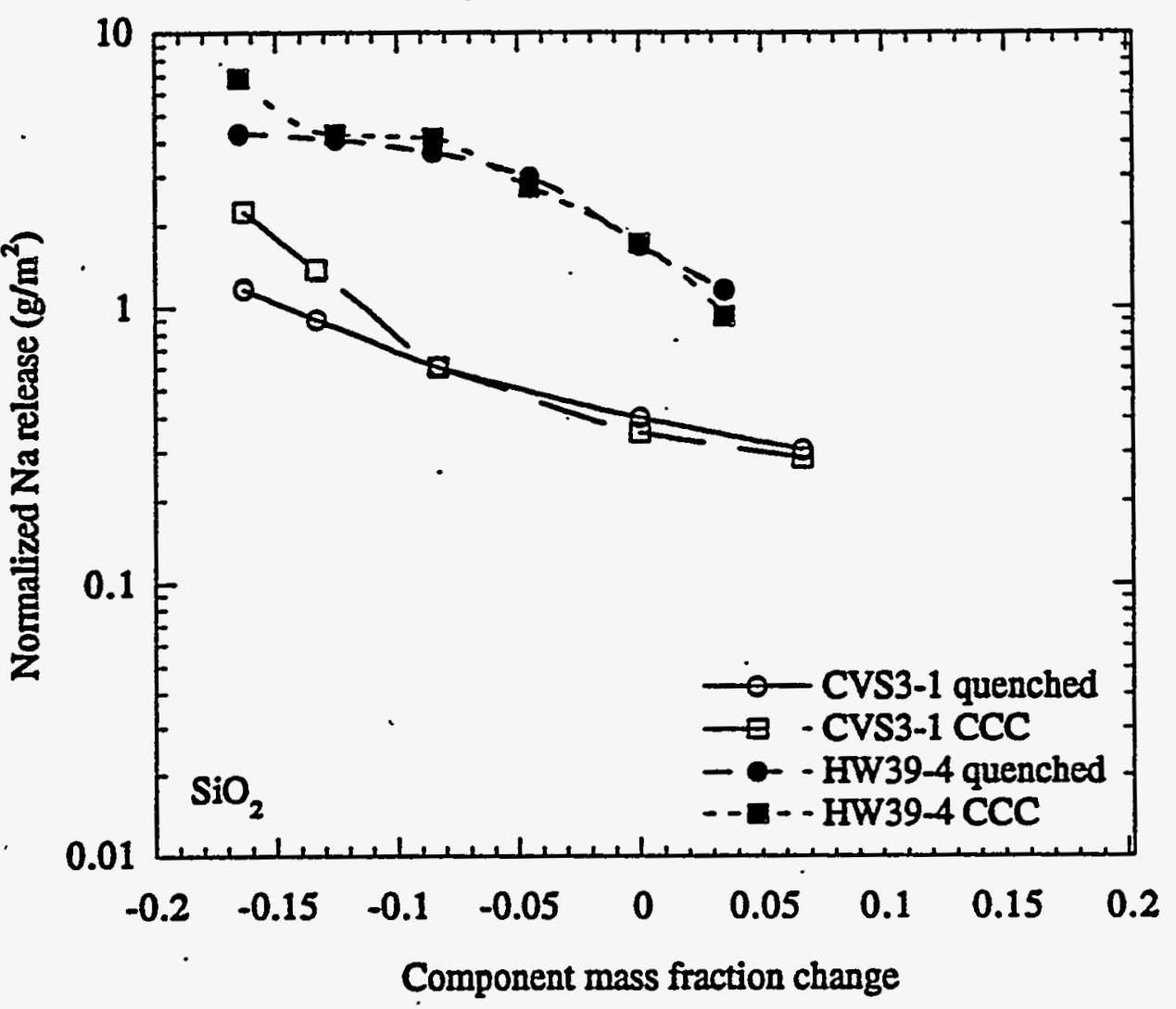

Figure 6. Normalized Na release from 7-day PCT of quenched and CCC glasses as a function of $\mathrm{SiO}_{2}$ concentration.

\section{$5.2 \quad \mathrm{Na}_{2} \mathrm{O}$}

In a silicate glass, sodium is incorporated as a $\mathrm{Na}+$ ion which is charge-compensated by the creation of a non-bridging oxygen (NBO) ion. The creation of NBO's in a silicate glass lowers network connectivity and degrades durability. However, the specific (or quantitative) effect of $\mathrm{Na}_{2} \mathrm{O}$ varies with overall glass composition due to interactions with $\mathrm{Al}_{2} \mathrm{O}_{3}, \mathrm{~B}_{2} \mathrm{O}_{3}$ and other components (DeYoreo and Navrotsky 1990). $\mathrm{Na}_{2} \mathrm{O}$ also affects glass redox (Schreiber et al. 1994) and would affect the durability of glasses with high concentrations of transition metals such as iron. The indirect effect of redox may not be seen in these glasses because the glass is unable to reach redox equilibrium with air during the short melting period ( 2 hour) used to fabricate all glasses in this study. 


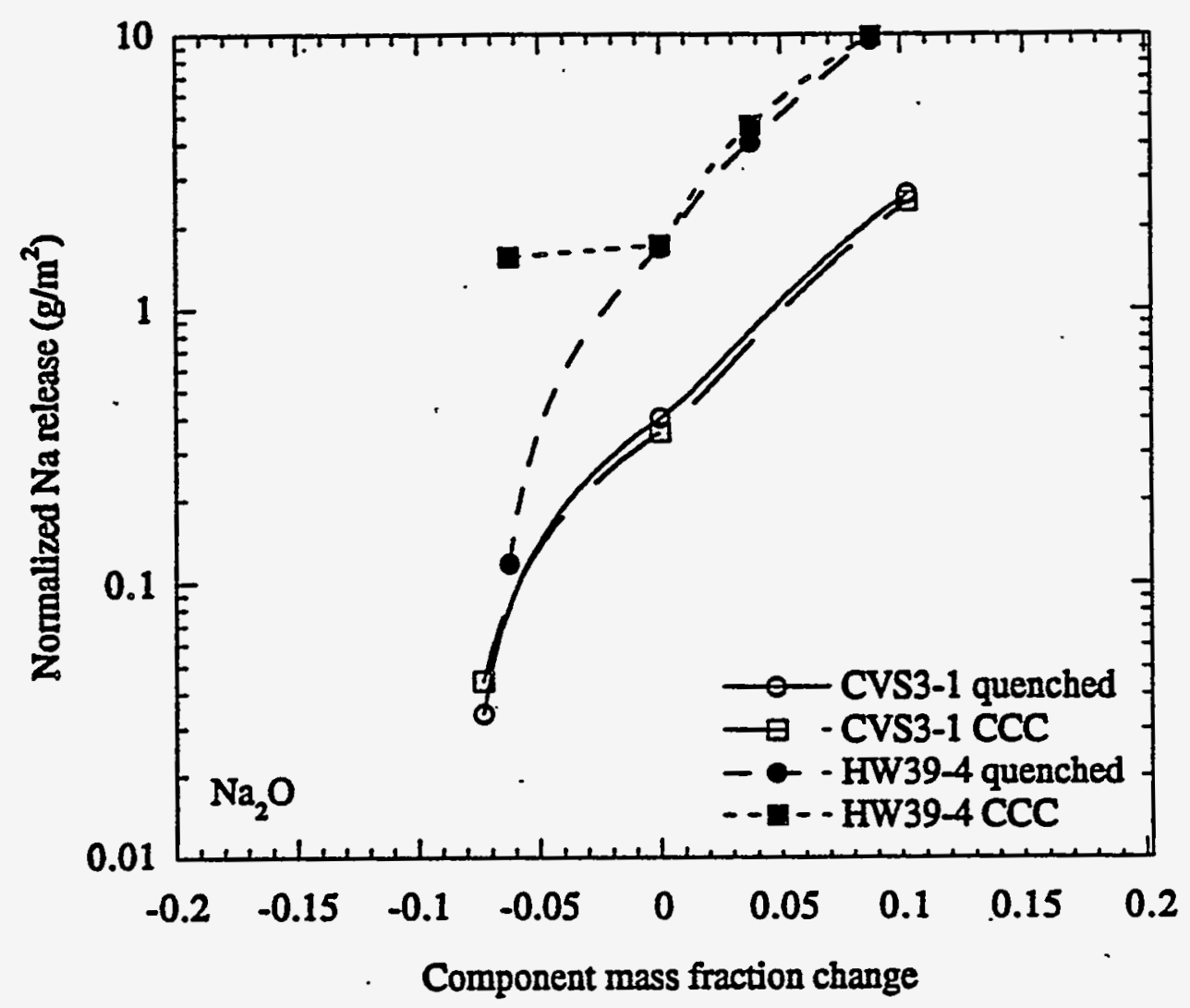

Figure 7. Normalized release from 7-day PCT of quenched and CCC glasses as a function of $\mathrm{Na}_{2} \mathrm{O}$ concentration.

Figure 7 displays the effect of $\mathrm{Na}_{2} \mathrm{O}$ on the $\mathrm{INa}_{\mathrm{Na}}$ of CVS3-1 and HW39-4 glasses. The effect of $\mathrm{Na}_{2} \mathrm{O}$ on $\ln \mathrm{I}_{\mathrm{Na}}$ as measured at CVS3-1 is 27.23 which is somewhat lower than that measured at HW $39-4$ composition (32.52). The effect of $\mathrm{CCC}$ is evident in the less durable $\mathrm{HW} 39-4$ glass with the lowest $\mathrm{Na}_{2} \mathrm{O}$ concentration. This glass is susceptible to amorphous phase separation which likely caused the decrease in CCC glass durability (Peeler and Hrma 1994).

\section{$5.3 \quad \mathrm{Li}_{2} \mathrm{O}$}

Like $\mathrm{Na}_{2} \mathrm{O}, \mathrm{Li}_{2} \mathrm{O}$ decreases glass durability by creating $\mathrm{NBO}$ 's and loosening the glass network. All interactions discussed for $\mathrm{Na}_{2} \mathrm{O}$ also apply to $\mathrm{Li}_{2} \mathrm{O}$, plus an additional interaction known as the mixed alkali effect. This is a nonadditive effect of combined alkaline oxides on a glass property and is generally. 


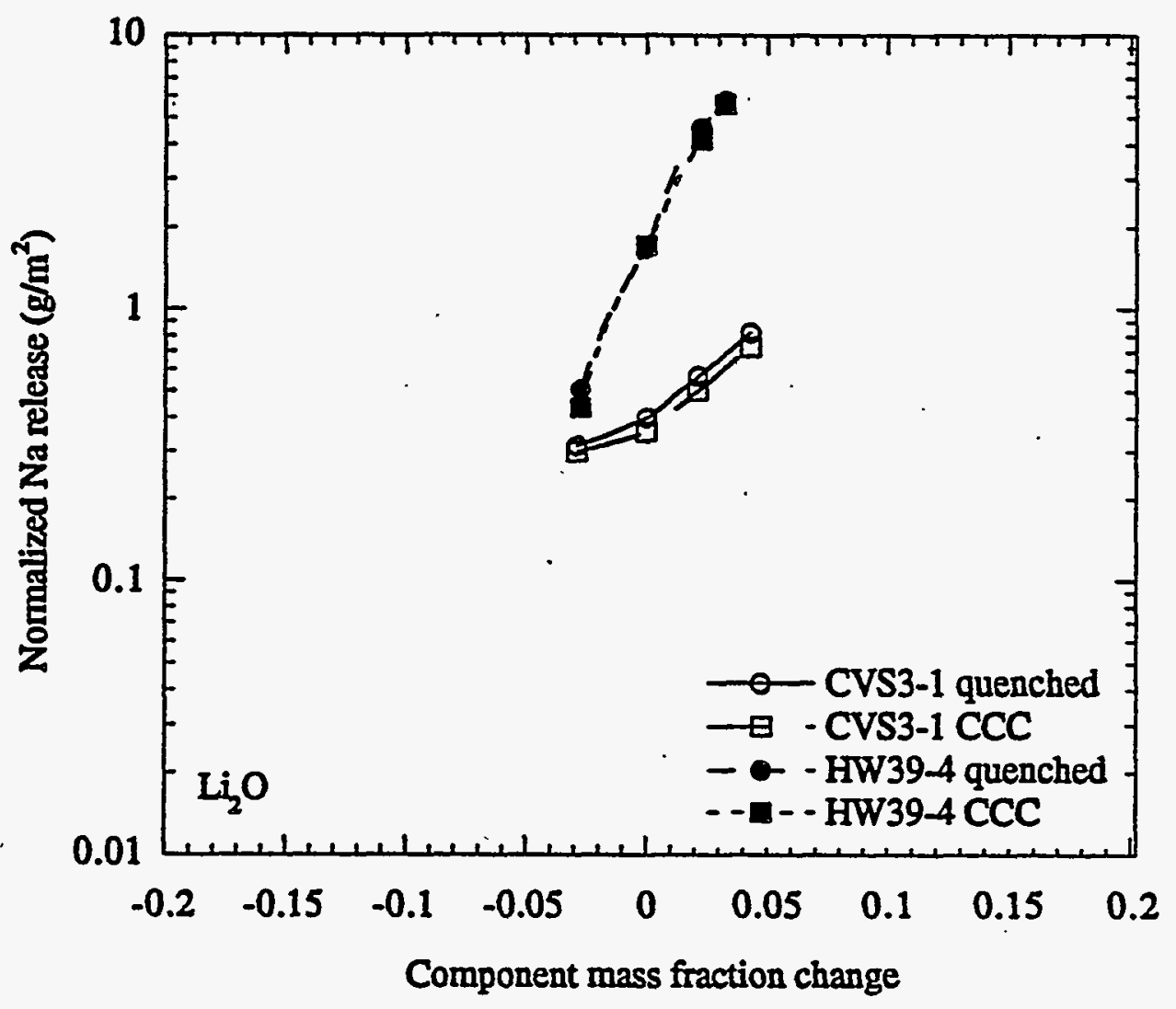

Figure 8. Normalized release from 7-day PCT of quenched and CCC glasses as a function of $\mathrm{Li}_{2} \mathrm{O}$ concentration.

Figure 8 displays the effect of $\mathrm{Li}_{2} \mathrm{O}$ on the $\mathrm{I}_{\mathrm{Na}}$ of CVS3-1 and HW39-4 glasses. The effect of $\mathrm{Li}_{2} \mathrm{O}$ on In $\mathrm{I}_{\mathrm{N}}$ as measured at CVS3-1 is 12.20 which is significantly lower than that measured at $\mathrm{HW} 39-4$ composition (42.00). The averaged effect of $\mathrm{Li}_{2} \mathrm{O}$ (in CVS-I and -I) is 19.27. The large differences in $\mathrm{Li}_{2} \mathrm{O}$ effect from one baseline glass to another are in sharp contrast with the effect of $\mathrm{Na}_{2} \mathrm{O}$ which does not change significantly from glass to glass, suggesting interactions of $\mathrm{Li}_{2} \mathrm{O}$ with other glass components such as $\mathrm{B}_{2} \mathrm{O}_{3}$ and $\mathrm{Al}_{2} \mathrm{O}_{3}$ (see discussion in Section 5.1). CCC treatment didn't markedly change the $\mathrm{T}_{\mathrm{N} 2}$ of these glasses.

\section{$5.4 \quad \mathrm{~B}_{2} \mathrm{O}_{3}$}

Boron can enter a silicate glass as a network forming $\mathrm{BO}_{4}$ - ion which is normally chargecompensated by association with an alkali atom. Although $\mathrm{BO}_{4}$ - is not bonded as strongly as $\mathrm{SiO}_{2}$ tetrahedra (or as durable) in a silicate network, its association with $\mathrm{Na}$ + is electrostatic and, hence, stronger. Bunker (1994) reports that $\mathrm{BO}_{4}$ and $\mathrm{AlO}_{4}$ - sites are five orders of magnitude more resistant to ion exchange than NBO sites. Due to this decrease in NBO concentrations, $\mathrm{B}_{2} \mathrm{O}_{3}$ improves glass durability at low to moderate concentrations (usually up to $6 \mathrm{wt} \%$ ). Excessive concentration of $\mathrm{B}_{2} \mathrm{O}_{3}$ enters the glass network in threefold coordination which doesn't lower 
NBO concentrations and decreases network strength (Volf 1984). As the relative alkali concentration is increased, the $\mathrm{B}^{4}: \mathrm{B}^{3}$ ratio reaches a maximum, and then decreases; this is known. as the boron anomaly (LaCourse and Stevens 1977). In general, $\mathrm{B}_{2} \mathrm{O}_{3}$ increases glass durability at Jow concentrations and decreases durability at high concentrations. This effect has been demonstrated by replacing $\mathrm{SiO}_{2}$ by $\mathrm{B}_{2} \mathrm{O}_{3}$ (Kim 1994) or $\mathrm{Na}_{2} \mathrm{O}$ by $\mathrm{B}_{2} \mathrm{O}_{3}$ (Bunker 1987) in simple glass compositions.

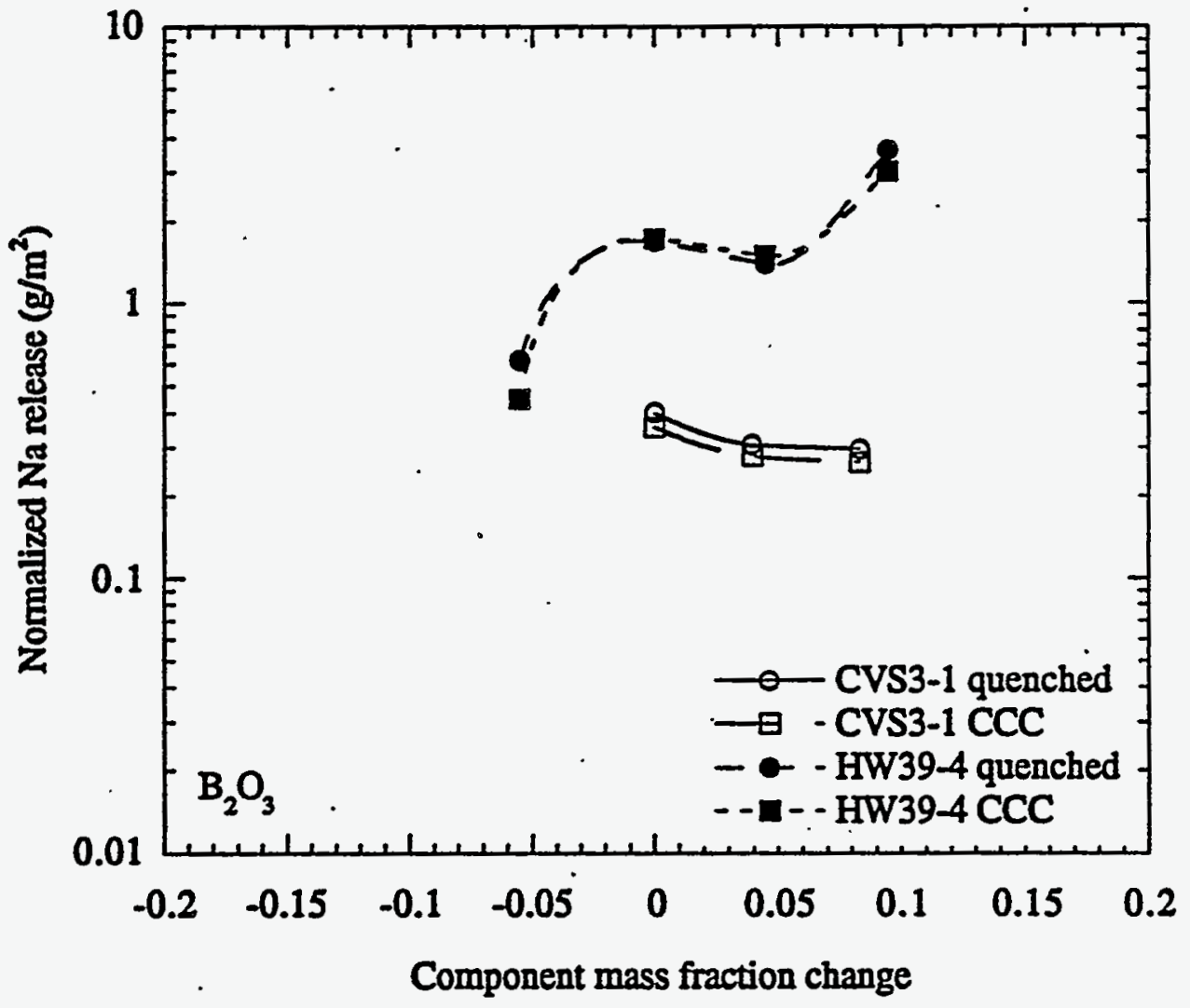

Figure 9. Normalized release from 7-day PCT of quenched and CCC glasses as a function of $\mathrm{B}_{2} \mathrm{O}_{3}$ concentration.

Figure 9 displays the effect of $\mathrm{B}_{2} \mathrm{O}_{3}$ on the $\mathrm{I}_{\mathrm{Na}}$ of CVS3-1 and HW39-4. The strong nonlinear effect of boron is demonstrated by the differences between the measured effects at each baseline composition: -9.48 at CVS3-1 $\left(\mathrm{g}_{\mathrm{B}_{2}} \mathrm{O}_{3}=0.0005\right)$ and 10.47 at HW39-4. $\left(\mathrm{g}_{\mathrm{B}_{2}} \mathrm{O}_{3}=0.1048\right)$. This effect is also shown by the curvature of the second-order model predictions (Hrma, Piepel, et al., 1994).

\section{5 $\quad \mathrm{Fe}_{2} \mathrm{O}_{3}$}

The effect of iron on glass durability depends on the redox state of the glass. In general, addition of $\mathrm{Fe}_{2} \mathrm{O}_{3}$ increases glass durability while $\mathrm{FeO}$ decreases durability. $\mathrm{Fe}_{2} \mathrm{O}_{3}$ may also enter the network in four- and six-fold coordination and is prone to association with alkali ions (Volf, 
1984). Figure 10 displays the effect of $\mathrm{Fe}_{2} \mathrm{O}_{3}$ on the $\mathrm{I}_{\mathrm{Na}}$ of CVS3-1. The effect of $\mathrm{Fe}_{2} \mathrm{O}_{3}$ on $\ln \mathrm{I}_{\mathrm{Na}}$ as measured at CVS3-1 is -4.11 . The effect of $\mathrm{Fe}_{2} \mathrm{O}_{3}$ on HW39-4 has not been measured. The averaged effect of $\mathrm{Fe}_{2} \mathrm{O}_{3}$ on CVS-I and -II glasses is virtually the same $(-4.97)$ as that for the CVS3-1 glass. CCC treatment effects on the durability of the CVS-III iron glasses result from crystallization as described in Section 5.12.

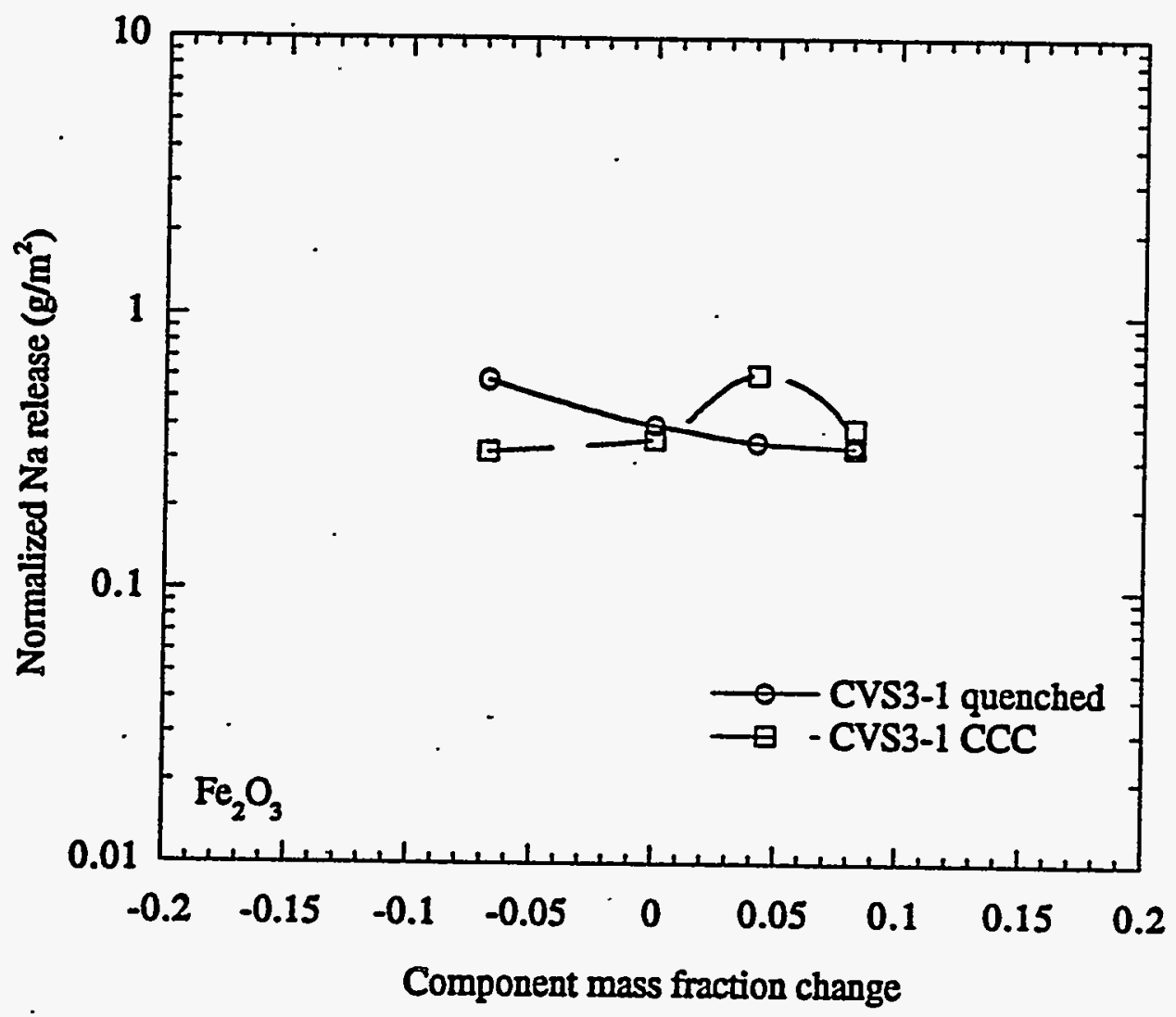

Figure 10. Normalized release from 7-day PCT of quenched and CCC glasses as a function of $\mathrm{Fe}_{2} \mathrm{O}_{3}$ concentration.

\section{6 $\quad \mathrm{Al}_{2} \mathrm{O}_{3}$}

Like $\mathrm{B}_{2} \mathrm{O}_{3}, \mathrm{Al}_{2} \mathrm{O}_{3}$ increases glass durability by decreasing $\mathrm{NBO}$ concentration. $\mathrm{Al}_{2} \mathrm{O}_{3}$ is strongly bonded to the glass network in both four- and six-fold coordinations. Hence, $\mathrm{Al}_{2} \mathrm{O}_{3}$ has not been seen to decrease the durability (by 7-day PCT) of glasses. The positive effects of $\mathrm{Al}_{2} \mathrm{O}_{3}$ are generally more dramatic in glasses with low network former and high alkali concentrations. Figure 11 displays the effect of $\mathrm{Al}_{2} \mathrm{O}_{3}$ on the $\mathrm{r}_{\mathrm{Na}}$ of CVS3-1 and $\mathrm{HW} 39-4$ glasses. The effect of $\mathrm{Al}_{2} \mathrm{O}_{3}$ on $\ln \mathrm{I}_{\mathrm{Na}}$ as measured at CVS3-1 is -17.34 which is lower than that measured at HW39-4 composition (-42.95) and similar to than that measured at the WV205 composition (-14.23). The curvature of the in $\mathrm{I}_{\mathrm{Na}}$ versus $\mathrm{Al}_{2} \mathrm{O}_{3}$ change line shows a nonlinear effect which is strongest (accidentally) near baseline compositions. 


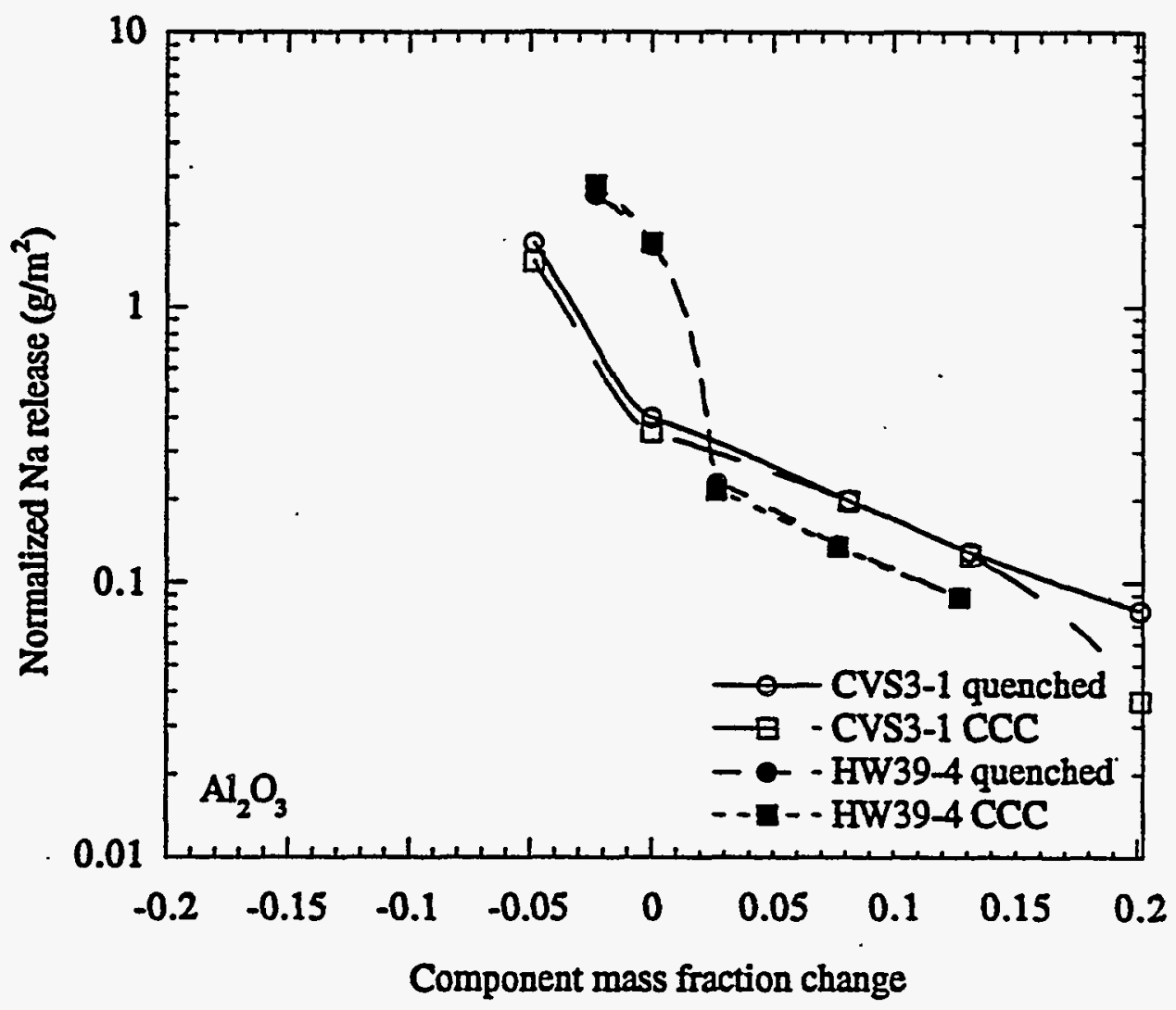

Figure 11. Normalized release from 7-day PCT of quenched and CCC glasses as a function of $\mathrm{Al}_{2} \mathrm{O}_{3}$ concentration.

Interestingly, Figure 11 demonstrates that a small increase in $\mathrm{Al}_{2} \mathrm{O}_{3}$ content would significantly improve the durability of $\mathrm{HW} 39-4$ glass. Unexpectedly, the $\mathrm{Al}_{2} \mathrm{O}_{3}$ enriched $\mathrm{HW} 39-4$ glass exhibited somewhat higher durability than the CVS3-1 glass with the same addition of $\mathrm{Al}_{2} \mathrm{O}_{3}$. The plot implies that the effect of $\mathrm{Al}_{2} \mathrm{O}_{3}$ may not be accurately described by a second-order model over large composition regions, although the approximation could be satisfactory. At higher $\mathrm{Al}_{2} \mathrm{O}_{3}$ concentrations, the effect is virtually linear with similar slopes for CVS3-1 (-8.11) and HW39-4 (-9.45). CCC treatment of the CVS3-16 glass (25 wt\% $\left.\mathrm{Al}_{2} \mathrm{O}_{3}\right)$ resulted in nearly complete crystallization. The glass ceramics produced had an improved durability over quenched glass (with less than 4 vol\% crystalline phases).

\section{$5.7 \quad \mathrm{ZrO}_{2}$}

$\mathrm{ZrO}_{2}$, like $\mathrm{SiO}_{2}$ is a network forming component in glass and generally increases glass durability. The effect of $\mathrm{ZrO}_{2}$ on $\mathrm{I}_{\mathrm{Na}}$ of the CVS3-1 baseline glass is shown in Figure 12 (it was not measured for $\mathrm{HW} 39-4$ glass). The apparent effect of $\mathrm{ZO}_{2}$ on the $\mathrm{r}_{\mathrm{Na}}$ of this glass is nonlinear, however this has not been seen in previous empirical modelling of glass durability. Sample analysis disclosed undissolved $\mathrm{ZrO}_{2}$ in the 12 and $8 \mathrm{wt} \% \mathrm{ZrO}_{2}$ samples (two highest change data points) which may account for the apparent nonlinearity. The effect of $\mathrm{ZrO}_{2}$ on $\ln \mathrm{I}_{\mathrm{N} 2}$ as measured 
at CVS3-1 is.-7.79 which is similar to that measured at WV205 (-8.85) and somewhat lower than the averaged CVS-I and -II effect $(-12.42)$. CCC treatment increased the release of the two highest $\mathrm{ZrO}_{2}$ glasses.

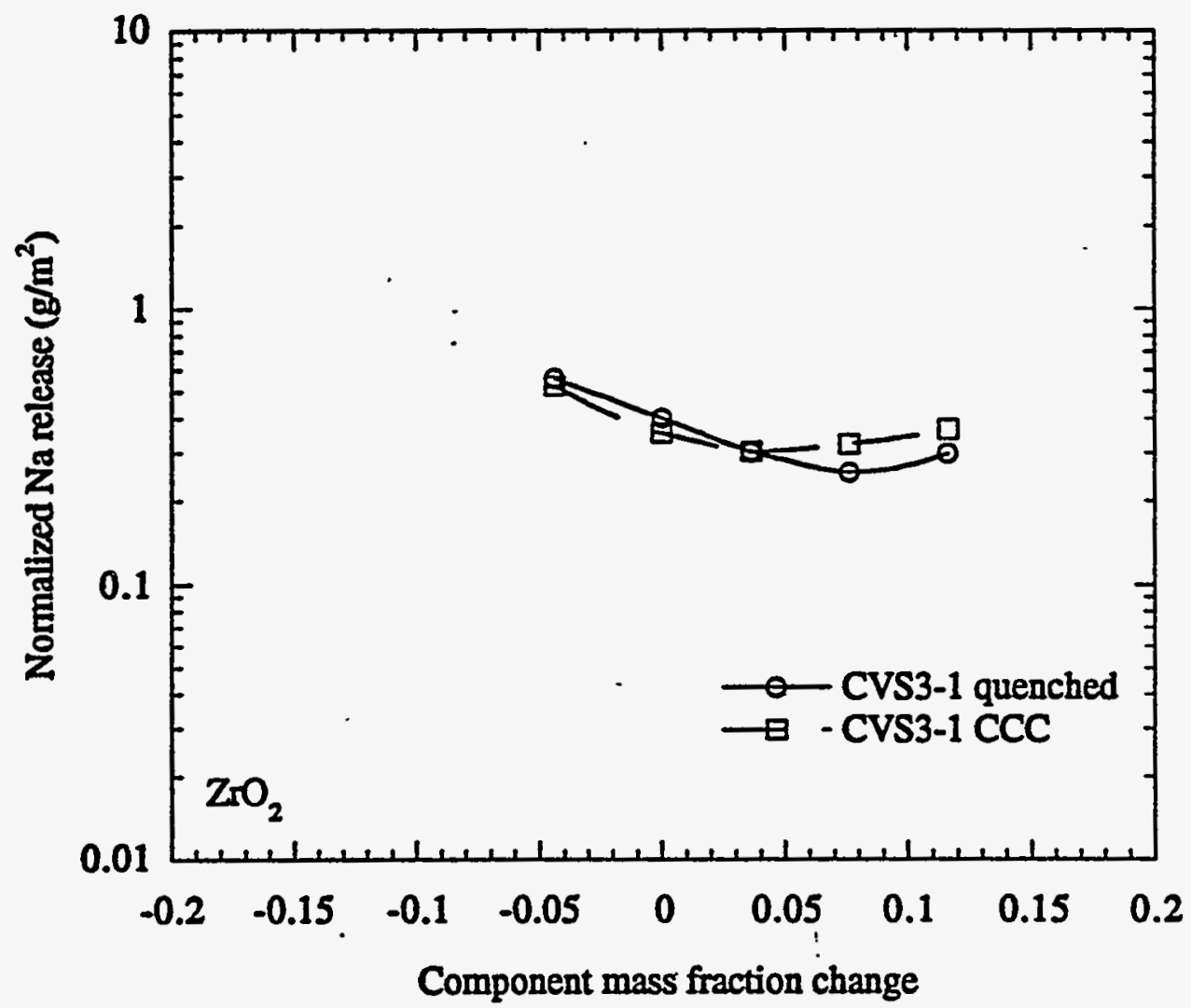

Figure 12. Normalized release from 7-day PCT of quenched and CCC glasses as a function of $\mathrm{ZrO}_{2}$ concentration.

\subsection{Others}

The pseudo-component Others (including small concentrations of $\mathrm{Bi}_{2} \mathrm{O}_{3}$ and $\mathrm{P}_{2} \mathrm{O}_{5}$ ) was also varied in this study. This component consists of a mixture of minor waste components which are not thought to have a significant effect on glass durability if Others remains in low concentration in glass. The concentrations of Others was increased to $20 \mathrm{wt} \%$ in the baseline glass to ensure this particular Others composition (from all-blend waste, see Section 10.1) would not significantly affect the durability of glass at very high waste loadings. Figure 13 displays the effect of Others on the $r_{\mathrm{Na}_{2}}$ of CVS3-1. The effect of Others on $\ln 1_{\mathrm{N}_{2}}$ as measured at CVS3-1 is -0.97 . The assumption of Others having little effect on glass PCT is upheld by this data. 


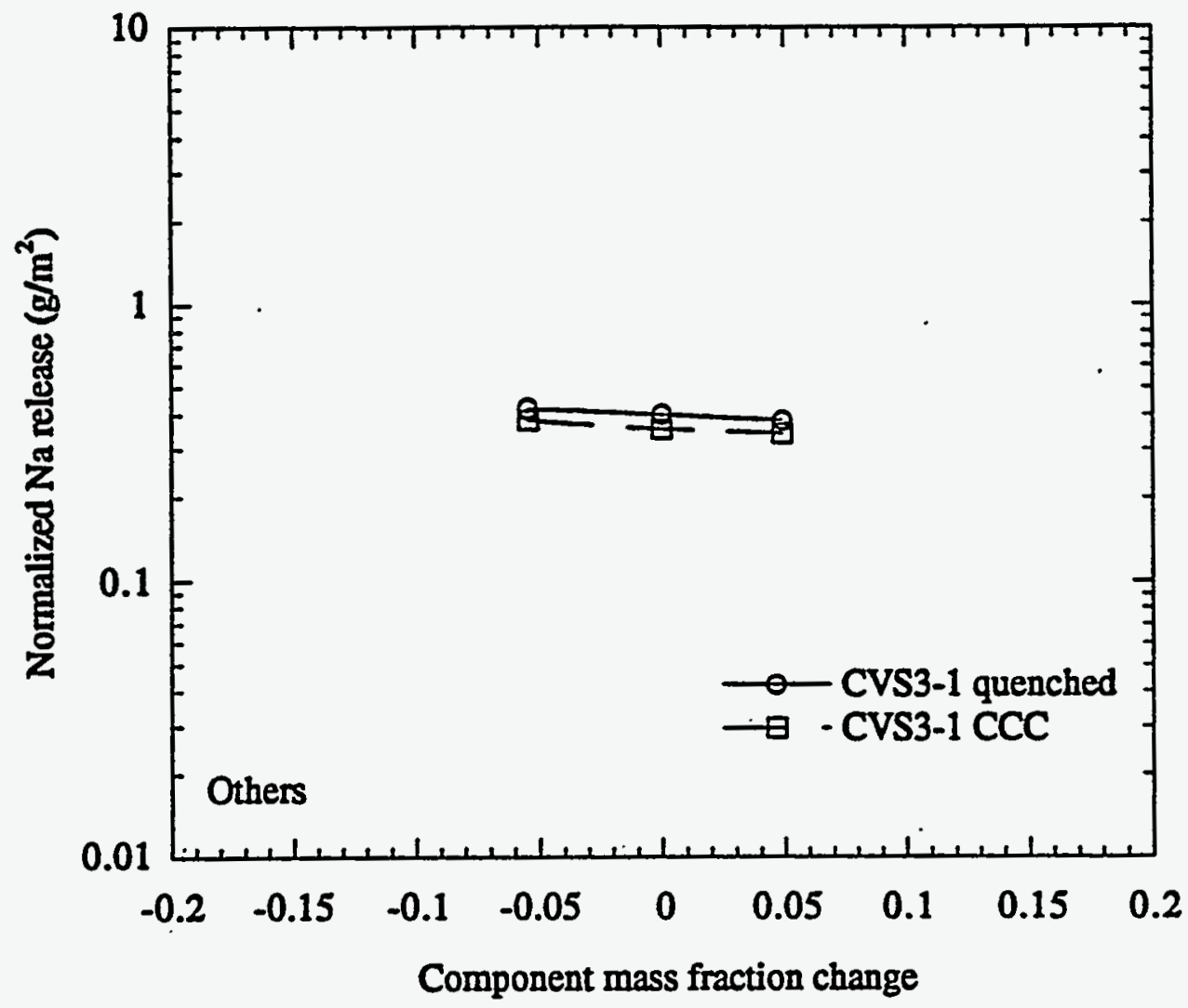

Figure 13. Normalized release from 7-day PCT of quenched and CCC glasses as a function of Others concentration.

\section{$5.9 \quad \mathrm{Bi}_{2} \mathrm{O}_{3}$}

$\mathrm{Bi}_{2} \mathrm{O}_{3}$ is a network modifying component in glass and affects glass properties much like $\mathrm{PbO}$. $\mathrm{Bi}_{2} \mathrm{O}_{3}$ is capable of lowering glass viscosity while not degrading glass durability. Although $\mathrm{Bi}_{2} \mathrm{O}_{3}$ has not been considered as an additive for nuclear waste vitrification, its presence in waste is generally helpful to glass formulation. Figure 14 displays the effect of $\mathrm{Bi}_{2} \mathrm{O}_{3}$ on the $\mathrm{I}_{\mathrm{N} 2}$ of CVS31. A slight increase in $\mathrm{T}_{\mathrm{Na}}$ is seen with increasing concentration. The effect of $\mathrm{Bi}_{2} \mathrm{O}_{3}$ on glass durability as measured at CVS3-1 is 0.42 the effect of $\mathrm{Bi}_{2} \mathrm{O}_{3}$ is not available for $\mathrm{HW} 39-4$ or WV205 compositions. The $I_{\mathrm{Na}}$ of these glasses was decreased slightly by $\mathrm{CCC}$ treatment. 
PVTD-C95-02.01E/J

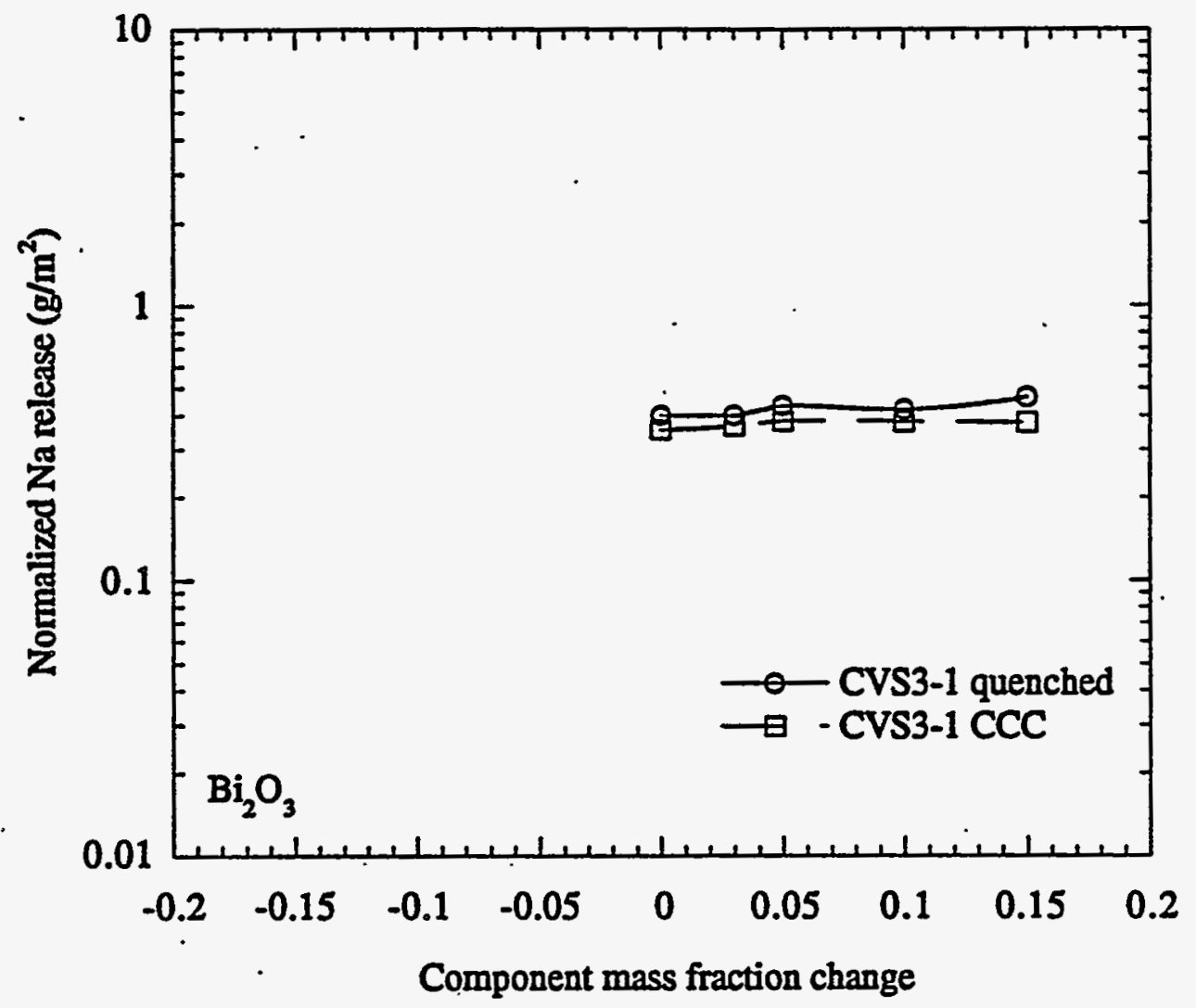

Figure 14. Normalized release from 7-day PCT of quenched and CCC glasses as a function of $\mathrm{Bi}_{2} \mathrm{O}_{3}$ concentration.

\section{$5.10 \mathrm{P}_{2} \mathrm{O}_{5}$}

Phosphate is a glass forming component. In an alumino-boro-silicate glass, however, the solubility of $\mathrm{P}_{2} \mathrm{O}_{5}$ is limited. $\mathrm{Al}_{2} \mathrm{O}_{3}$ has been used to increase phosphate solubility in silicate glasses. However, in boro-silicate glasses the incorporation of $\mathrm{P}_{2} \mathrm{O}_{5}$ is enabled by $\mathrm{Na}_{2} \mathrm{O}$ because $\mathrm{Al}_{2} \mathrm{O}_{3}$ competes for $\mathrm{Na}$ with $\mathrm{P}_{2} \mathrm{O}_{5}, \mathrm{Al}_{2} \mathrm{O}_{3}$ lowers $\mathrm{P}_{2} \mathrm{O}_{5}$ solubility in these glasses. Discussion of $\mathrm{P}_{2} \mathrm{O}_{5}$ in waste glass is given by $\mathrm{Li}(1995)$. Figure 15 displays the effect of $\mathrm{P}_{2} \mathrm{O}_{5}$ on the $\mathrm{I}_{\mathrm{Na}}$ of CVS3-1. A decrease in $\mathrm{I}_{\mathrm{Na}}$ is seen with increasing concentration. The effect of $\mathrm{P}_{2} \mathrm{O}_{5}$ on glass durability as measured at CVS3-1 is -8.42 , which is similar to that measured at HTB651 (-11.17) and PFP (-12.44) glasses. The effect of $\mathrm{P}_{2} \mathrm{O}_{5}$ is not available for HW39-4 or WV205 compositions. 


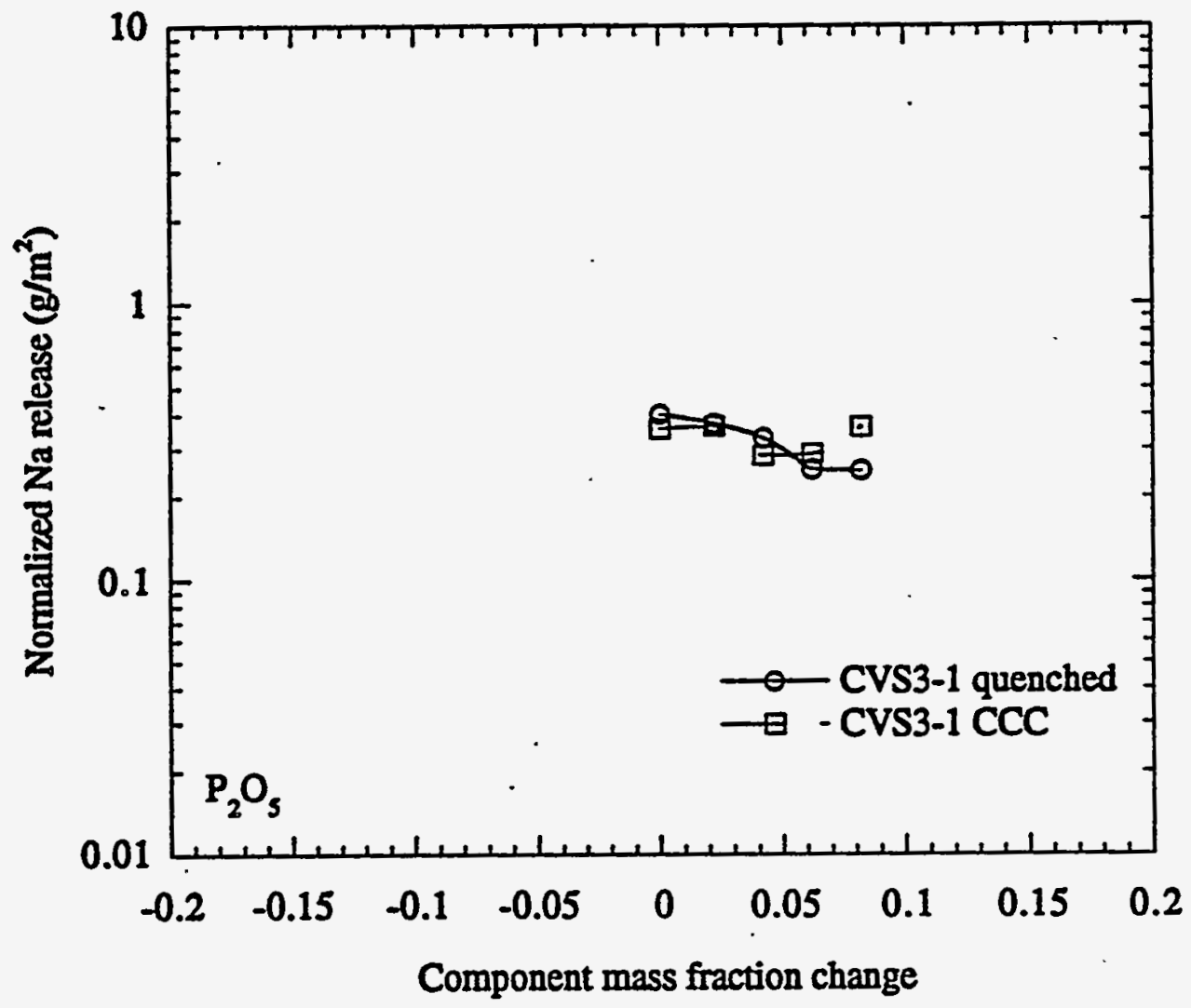

Figure 15. Normalized release from 7-day PCT of quenched and CCC glasses as a function of $\mathrm{P}_{2} \mathrm{O}_{5}$ concentration.

\section{$5.11 \mathrm{UO}_{2}$}

Uranium enters the glass network in three oxidation states UN, $U$, and $U V$, of which UVI has the highest solubility in glass (Schreiber and Balazs 1982). Glasses melted in an oxidizing atmosphere with high $U$ concentrations, such as those considered in this study, will contain an oxide of UV. However, $U$ was batched in these glasses as $U N$ and is therefore reported as $\mathrm{UO}_{2}$.

Uranium is found in high concentrations in the tank waste at Hanford and will likely be seen in all HLW glasses. The cost of glass testing has prohibited the use of $U$ in simulated glasses tested for CVS. $\mathrm{Nd}_{2} \mathrm{O}_{3}$ was used as a uranium surnogate in a majority of glass testing. One purpose of this study is to evaluate the use of $\mathrm{Nd}_{2} \mathrm{O}_{3}$ as a uranium substitute.

As seen in Figure 16, $\mathrm{UO}_{2}$ has little effect on the $\mathrm{I}_{\mathrm{N}}$ of $\mathrm{CVS3}-32$, which was the baseline for $\mathrm{UO}_{2}$ containing glasses (see Section 3.0). The effect of $\mathrm{UO}_{2}$ on In $\mathrm{I}_{\mathrm{Na}}$ as measured at CVS332 is -0.73 , the effect of $\mathrm{UO}_{2}$ is not available for HW39-4 or WV205 compositions. CCC had little effect on the $\mathrm{I}_{\mathrm{Na}}$ of these glasses. Replacing Nd in CVS3-1 by U in CVS3-32 resulted in a change in $r_{N_{a}}$ from 0.400 to $0.326 \mathrm{~g} / \mathrm{m}^{2}$, respectively. 


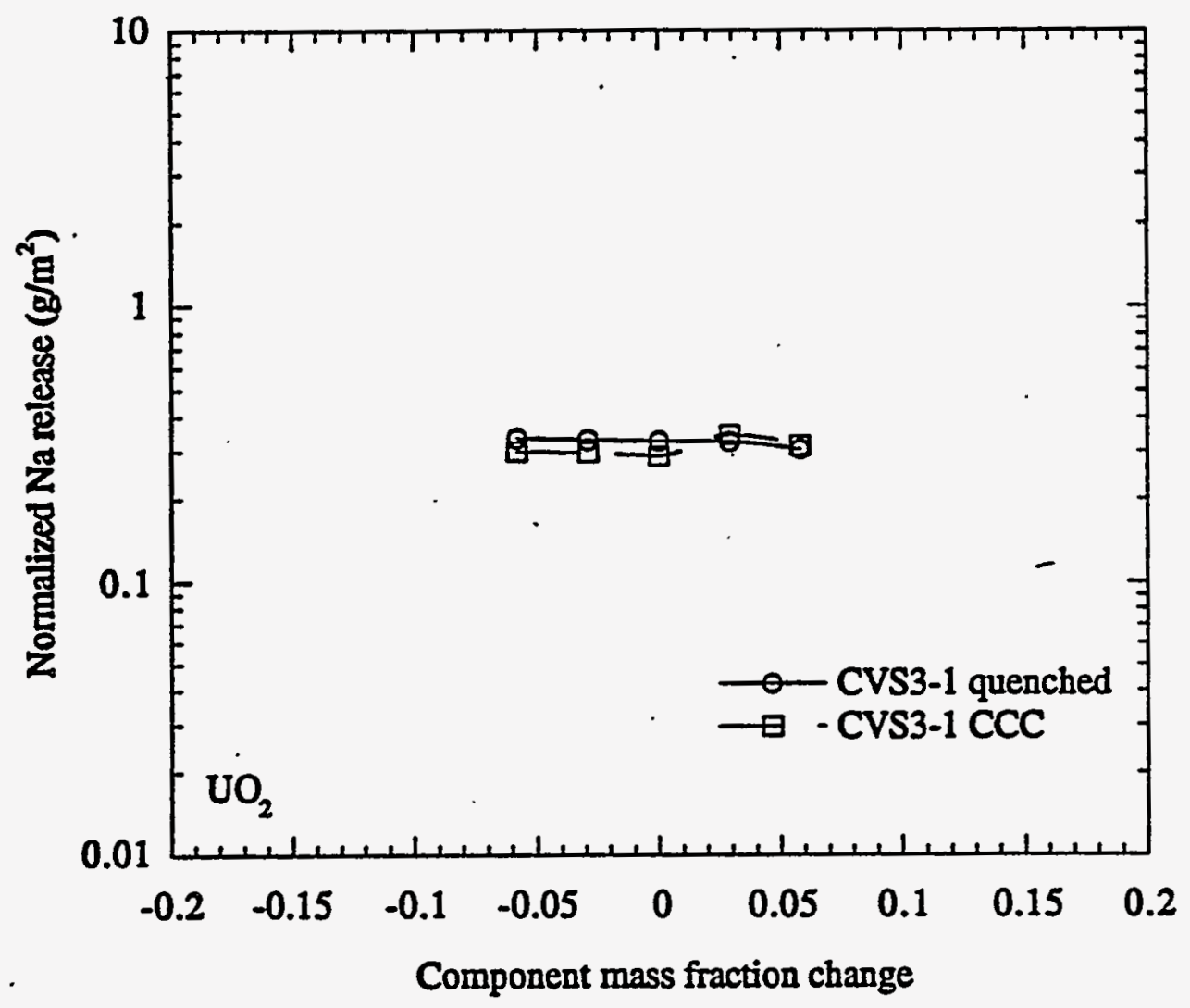

Figure 16. Normalized release from 7-day PCT of quenched and CCC glasses as a function of $\mathrm{UO}_{2}$ concentration.

\subsection{First-Order Model Coefficients}

First-order model coefficients for the release of $\mathrm{Na}, \mathrm{Si}$, and $\mathrm{Li}$ are given in Table $\mathrm{IX}$. The CVS-III coefficients were obtained by applying least squares regression to the whole set of CVSIII data including CVS3-26 (the CVS intemal standard glass). The CVS3-1L coefficients were obtained from linear regression of the In $r_{1}$ versus component change for individual components. The data were critically evaluated and outliers were deleted. The slopes where transformed to component coefficients by Equation (4) in which predicted response values were used for the baseline composition. The CVS3-1Q coefficients and those for HTB651, HW39-4 and PFP series were obtained in the same way except the slopes were calculated at the baseline composition from a second-order polynomial fit to experimental data. Where the second-order polynomial was not applicable, the CVS3-1L method was used (italicized).

The CVS3-1Q coefficients are equivalent to partial specific property values (Hrma and Robertus 1993). Their validity is restricted to a close neighborhood to the CVS3-1 composition. The CVS3-1L coefficients are averaged values over most of the CVS-III composition region (see Table D. Elimination of outliers and/or anomalous data might shrink this composition region 
somewhat. The CVS-III coefficients, taken from Piepel et al. (1995b), are based on a common predicted response value for the baseline composition.

The coefficients in Table IX can be used to calculate predicted PCT releases from glass compositions within their appropriate composition regions. Which coefficients (whether CVS-III or CVS3-1L) give better predictions cannot be determined until model validation is performed. Figures 17 and 18 show that some components exhibit significant nonlinear response. A systematic application of first- and second-order model techniques to all CVS data is provided by Piepel, et al. (1995b).

Table IX. First-order component coefficients for PCT logarithmic normalized sodium (a), silicon (b) and lithium (c) releases from quenched glasses.

(a)

\begin{tabular}{|c|c|c|c|c|c|c|}
\hline $\ln (\mathrm{NN} 2)$ & CVS-III & CVS3-1L & CVS3-1Q & HIB651 & HW39-4 & $\overline{\mathrm{PFP}}$ \\
\hline$\overline{\mathrm{SiO}_{2}}$ & -3.83 & -6.66 & -3.02 & & -4.88 & \\
\hline $\mathrm{B}: \mathrm{O}_{3}$ & 0.11 & -4.53 & -10.39 & & 9.57 & \\
\hline $\mathrm{Na} a \mathrm{O}$ & 19.05 & 22.98 & 22.96 & & 29.31 & \\
\hline LiOO & 13.39 & 12.74 & 12.75 & & 40.98 & \\
\hline $\mathrm{CaO}$ & & & & & 16.71 & \\
\hline $\mathrm{MgO}$ & & & & & 42.26 & \\
\hline $\mathrm{FecO}_{3}$ & -4.07 & -3.97 & -4.75 & & & \\
\hline $\mathrm{AllO}_{3}$ & -9.80 & -11.89 & -17.07 & & -41.94 & \\
\hline $\mathrm{ZrO}_{2}$ & -5.42 & -8.64 & -8.43 & & & \\
\hline $\mathrm{Biz}_{2} \mathrm{O}_{3}$ & -0.31 & -0.01 & -0.50 & & & \\
\hline $\mathrm{P}_{2} \mathrm{O}_{3}$ & -7.46 & -7.01 & -6.76 & -11.58 & & -15.56 \\
\hline $\mathrm{UO}_{2}$ & -4.03 & -1.86 & -1.78 & & & \\
\hline $\mathrm{Cr}_{2} \mathrm{O}_{3}$ & . & & & 10.56 & & \\
\hline $\mathrm{TiO}_{2}$ & & & & -5.76 & & \\
\hline Others & -3.97 & -1.71 & -1.76 & & & \\
\hline
\end{tabular}

(b)

\begin{tabular}{|c|rrrrrr|}
\hline In(rSi) & CVS-III & CVS3-1L & CVS3-10 & HTB651 & HW39-4 & PFP \\
\hline SiO2 & -3.02 & -5.01 & -3.21 & & -2.92 & \\
B2O3 & -0.61 & -2.53 & -4.31 & 0.13 & \\
Na20 & 6.85 & 8.52 & 6.07 & 11.09 & \\
Li20 & 12.19 & 13.30 & 11.92 & & 37.35 & \\
C2O & & & & 6.26 & \\
MgO & & & & & 17.93 & \\
Fe203 & -3.20 & -3.57 & -3.03 & & & \\
A1203 & -5.48 & -15.70 & -17.00 & & -29.83 & \\
ZO2 & -7.47 & -10.18 & -9.94 & & &. \\
Bi203 & -1.42 & -0.30 & 0.32 & & & \\
P2O5 & -6.44 & -4.12 & -4.52 & -3.64 & & -4.29 \\
UO2 & -3.34 & -0.95 & -1.02 & & & \\
C203 & & & & 10.50 & & \\
TiO2 & & & & -1.90 & & \\
Others & -0.30 & -2.38 & -2.42 & & & \\
\hline
\end{tabular}


(c)

\begin{tabular}{|c|ccccc|}
\hline In(rLi) & CVS-m & CVS3-1L & CVS3-10 & HW39-4 & PFP \\
\hline $\mathrm{SiO2}$ & -1.95 & -3.42 & -1.68 & -4.02 & - \\
$\mathrm{B} 203$ & 0.66 & -2.17 & -7.62 & 10.62 & \\
$\mathrm{Na} 20$ & 6.74 & 8.48 & 7.36 & 19.50 & \\
$\mathrm{Li2O}$ & 13.16 & 9.15 & 11.85 & 38.13 & \\
$\mathrm{C} 20$ & & & & 12.26 & \\
$\mathrm{MgO}$ & & - & & 36.45 & \\
$\mathrm{Fe2O3}$ & -3.40 & -4.59 & -3.59 & & \\
$\mathrm{~A} 1203$ & -2.06 & -11.51 & -13.37 & -35.76 & \\
$\mathrm{ZOO2}$ & -4.54 & -6.99 & -6.34 & & \\
$\mathrm{Bi2O3}$ & -1.44 & 0.01 & 0.00 & & \\
$\mathrm{P} 205$ & $-11: 83$ & -8.71 & -7.29 & & -5.05 \\
UO2 & -2.99 & 0.39 & 0.28 & & \\
Others & -2.51 & -1.63 & -1.68 & & \\
\hline
\end{tabular}

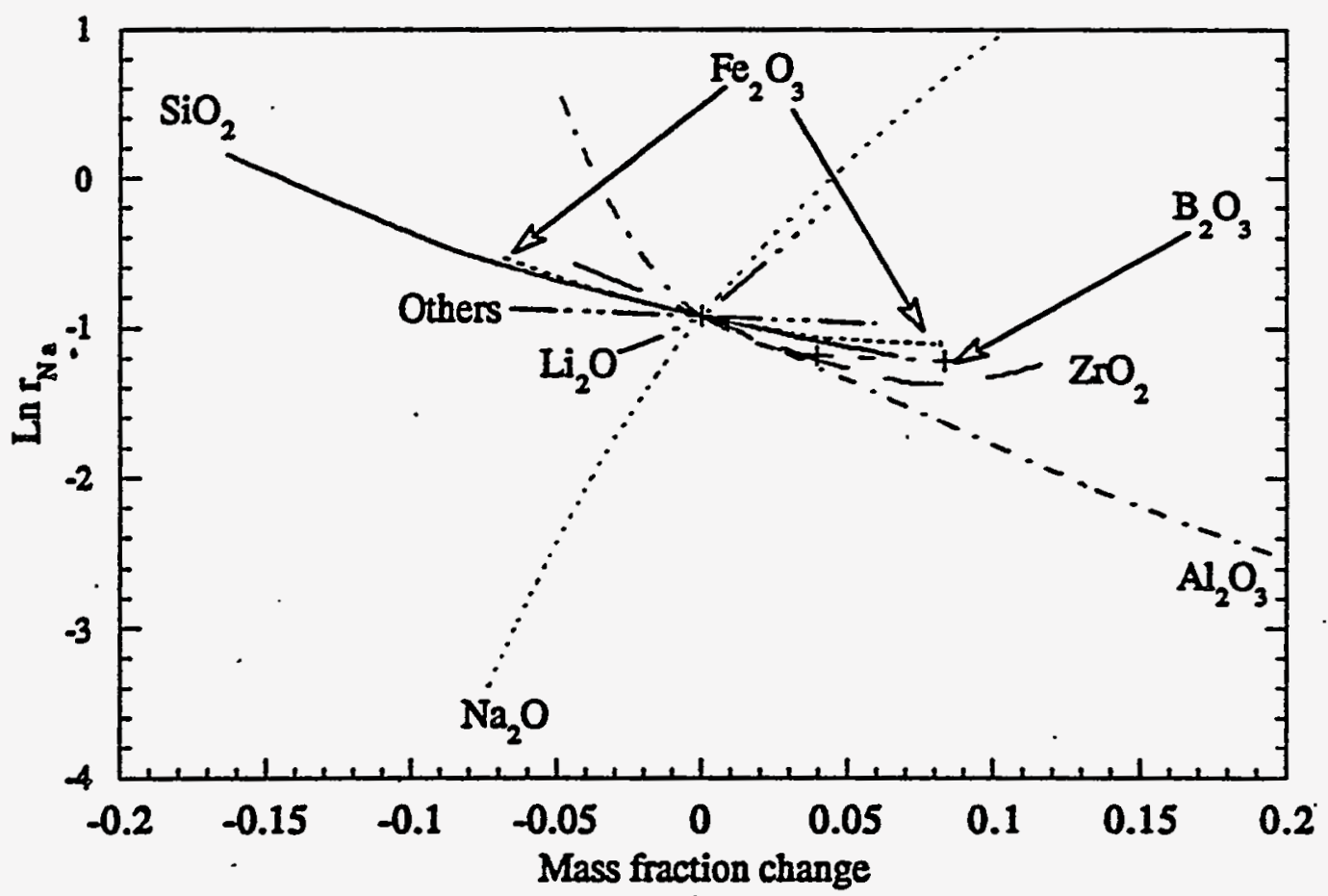

Figure 17. Normalized Na release as a function of component change from baseline glass. 


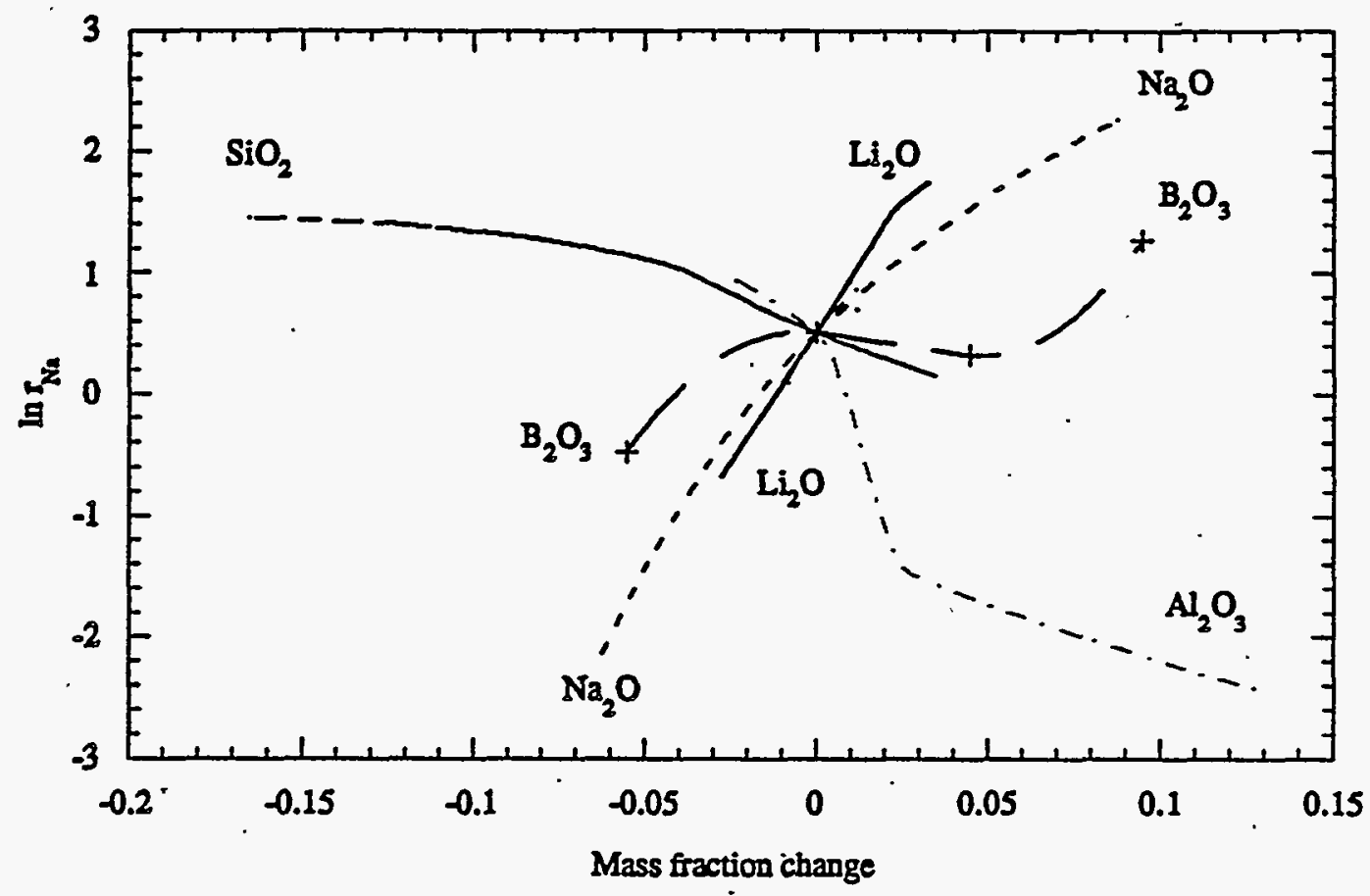

Figure 18. Normalized Na release as a function of component change from HW39-4 glass.

\subsection{Canister Centerline Cooling Crystallinity and its Effect on PCT}

The thermal history of a canister cooled glass has been a major concern in waste vitrification: In this complex process, part of the glass is quenched due to immediate contact with canister walls, while a portion of the glass located near the canister centerline is cooled slowly. Centerline cooling represents the lowest cooling rate which is typically experienced by glass in the canister, whereas quenching brackets the highest cooling rate. Hence, the thermal history of the glass in a canister falls in the range between quenched and centerline cooled. Cooled glass can also be reheated when it comes in contact with hot, freshly poured glass. This secondary phenomenon, which can affect crystallization, has not been addressed in the present study.

Heat treatment may affect chemical durability of glass. Mendel and McElroy (1972) have shown the durability of phosphate glasses to decrease by three orders of magnitude if heat treated at $620-650^{\circ} \mathrm{C}$ for $24 \mathrm{hr}$ or longer, but the effect was small when a boro-silicate glass received the same treatment. It was later shown that the decrease in durability was related to crystallization (Mendel, et al., 1977; Malow, et al., 1980). The effect of crystallization depends on thermal history plus the nature of crystalline phase present. Crystallization alters the surrounding glass composition, forms stresses, and may cause microcracking; all these may effect durability.

Durability of CCC glasses has been systematically measured previously in the CVS. Kim et al. (1995) showed a relationship between precipitation of certain crystalline phases and glass durability. The detrimental phases were nepheline, crystoballite, and eucriptite. The loss of durability was attributed to the change in residual glass composition. Crystoballite crystallization - resulted in an additional loss of durability due to internal stresses. If no crystallization occurs, CCC treatment leads to a slight increase in durability as a result of structural relaxation and densification of the glass. 
A simulated time/temperature history has been developed and verified for HLW glass melted at $1150^{\circ} \mathrm{C}$. by Lee (1989). The same cooling parameters have been applied to higher temperature melting HLW glasses (Langowski et al. 1994), see Figure 19.

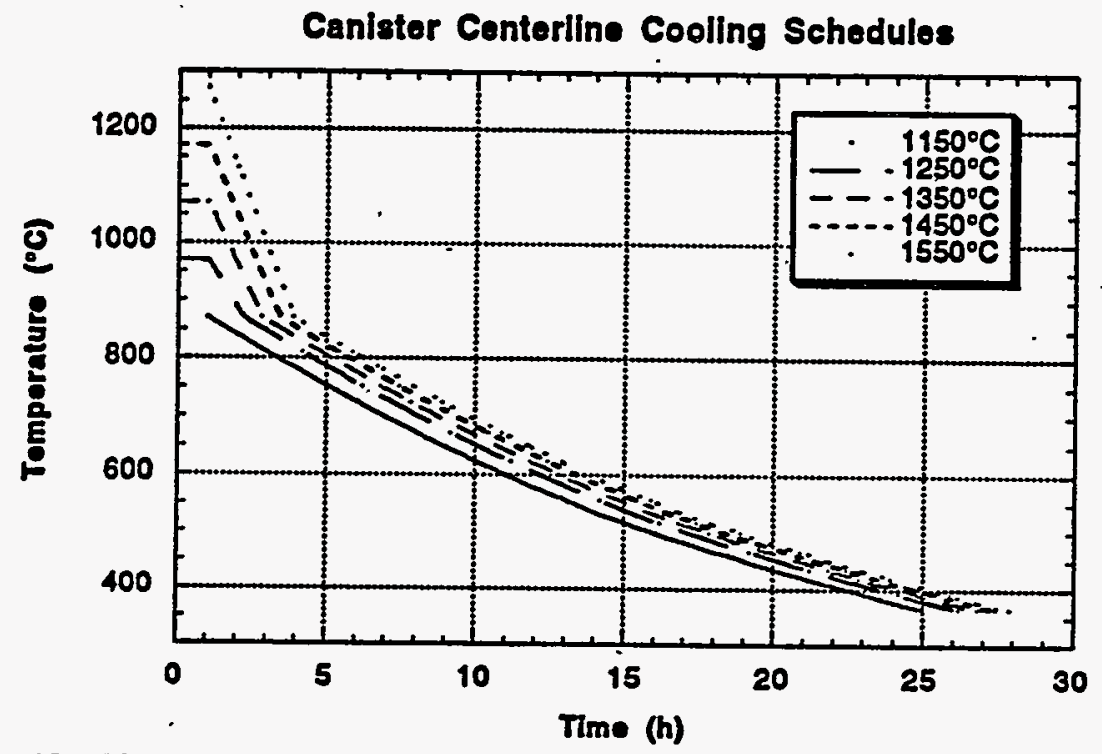

Figure 19. Simulated canister centerline cooling schedules for five starting temperatures.

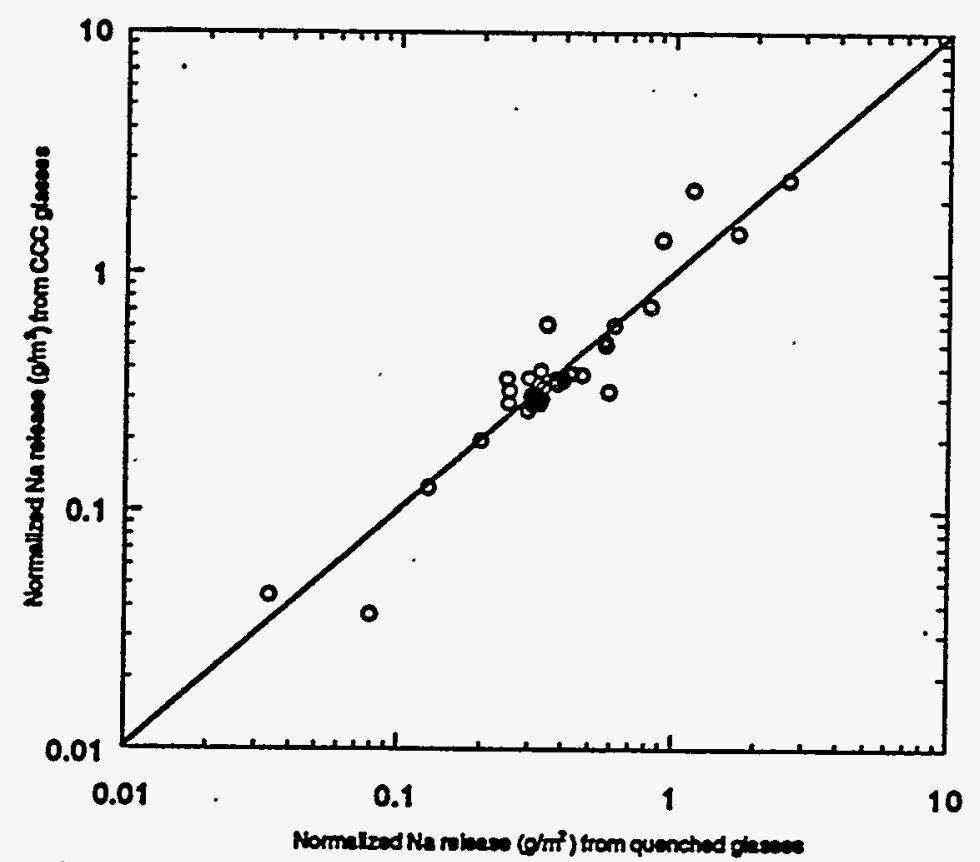

Figure 20. Comparison of $\mathrm{r}_{\mathrm{Na}}$ from quenched and canister centerline cooled glass samples. 
The crystallinity results for quenched and CCC glasses are listed in Section 10.4. The noimalized Na release of CCC glasses are compared to those from quenched samples in Figures 6 to 16 and 20. Generally, the durability of CVS-III glasses was not substantially effected by CCC treatment. Even glasses with high crystallinity (up to nearly 100 vol\%) showed little difference in $\mathrm{I}_{\mathrm{Na}}$ between quenched and CCC samples. Glasses with no crystallinity became generally more durable after $\mathrm{CCC}$ treatment. Crystallization often resulted in a decrease in durability with some exceptions. A more complete investigation into the effects of crystallinity on glass durability has been accomplished for CVS-I and -II glasses (Kim et al., 1995).

\subsection{Property Modelling}

First- and second-order mixture models (Equation (3)) have been fitted to selected transformed glass properties. The coefficients in Tables X and XI were obtained by applying least squares regression to the whole set of CVS-III data including the low-temperature CVS internal standard glass (CVS3-26). First- and second-order models for normalized PCT release from quenched and CCC CVS glasses are reported by Piepel et al. (1995b) along with more thorough discussion.

Table X. First-order model coefficients for selected glass properties.

\begin{tabular}{|c|c|c|c|c|c|c|c|c|c|c|c|c|}
\hline Coefficient & $\mathrm{SiO}_{2}$ & $\mathrm{~B}_{2} \mathrm{O}_{3}$ & $\mathrm{Na}_{2} \mathrm{O}$ & $\mathrm{Li}_{2} \mathrm{O}$ & $\mathrm{Fe}_{2} \mathrm{O}_{3}$ & $\mathrm{Al}_{2} \mathrm{O}_{3}$ & $\mathrm{ZO}_{2}$ & $\mathrm{Bi}_{2} \mathrm{O}_{3}$ & $\mathrm{P}_{2} \mathrm{O}_{5}$ & $\mathrm{UO}_{2}$ & Others & $\mathbf{R}^{2}$ \\
\hline$A\left(w / T_{\ell}\right)$ & -4.620 & 13.192 & -6.654 & 2.087 & -8.555 & -11.175 & -42.388 & $3-7.185$ & -13.283 & & -11.166 & 0.912 \\
\hline$B\left(w / T_{Q}\right)$ & 16,311 & $-38,632$ & $-6,026$ & $-57,091$ & 3,476 & 23,488 & $67,018^{\circ}$ & 4,788 & 27,165 & & 4,816 & 0.930 \\
\hline$T_{0}\left(w / T_{Q}\right)$ & 358.3 & $1,856.7$ & 429.7 & $1,040.4$ & 659.7 & 586.6 & -624.5 & 374.3 & 56.7 & & 784.4 & 0.752 \\
\hline$A\left(w / 0 T_{g}\right)$ & 8.812 & -22.281 & -31.884 & -41.916 & -12.713 & 10.971 & -11.214 & $4-1.611$ & 3.611 & 3.212 & -37.452 & 0.708 \\
\hline$B\left(w / 0 T_{g}\right)$ & $-10,370$ & 29.585 & 41,752 & 26,285 & 11,799 & $-19,054$ & $-1,578$ & $-5,855$ & $-10,948$ & $-4,286$ & 63,075 & 0.598 \\
\hline$\left|T_{0}\left(w / 0 T_{8}\right)\right|$ & $1,880.5$ & -1 & - & .1 & 248.9 & .1 & 5.0 & 801.7 & $1,863.3$ & $2,227.2$ & $-2,041.7$ & 0.709 \\
\hline$\overline{E_{\eta}}$ & 18.499 & 1.569 & -40.848 & -59.578 & -28.860 & -26.363 & -54.808 & -13.680 & -10.127 & -45.322 & -71.467 & 0.444 \\
\hline$F_{\eta}$ & $-12,356$ & $-19,434$ & 41,656 & 19,039 & 38,179 & 58,380 & 99,701 & 15,231 & 27,434 & 66,616 & 101,084 & 0.394 \\
\hline In $E_{M}$ & -3.878 & -2.256 & 8.148 & 8.187 & 2.011 & 3.051 & 4.533 & 1.337 & 3.130 & & 0.471 & 0.741 \\
\hline$\overline{E_{e}}$ & 8.420 & 7.176 & 9.010 & 24.394 & 9.641 & 4.285 & 15.197 & 10.092 & -1.154 & & 5.385 & 0.467 \\
\hline$F_{\varepsilon}$ & $-11,100$ & $-6,786$ & 5.765 & $-3,073$ & $-9,609$ & $-5,703$ & $-19,580$ & $-10,419$ & 6,116 & & $-1,527$ & 0.573 \\
\hline
\end{tabular}


Table XI. Second-order model coefficients for selected glass properties.

\begin{tabular}{|c|c|c|c|c|c|c|c|c|c|c|c|}
\hline & $A w / T_{B}$ & $\mathrm{~B} w / \mathrm{T}_{8}$ & $T_{0} w / T_{g}$ & $A w / 0 T_{8}$ & $\mathrm{~B} w / 0 \mathrm{~T}_{8}$ & $\mathrm{~T}_{0} \mathrm{w} / \mathrm{o} \mathrm{T}_{8}$ & $E_{\eta}$ & $F_{\eta}$ & In $\varepsilon_{M}$ & $E_{8}$ & $F_{\varepsilon}$ \\
\hline $\mathrm{SiO}_{2}$ & -4.899 & 16,690 & 384.4 & -2.262 & 434,210 & $-22,821.0$ & 569.795 & $-817,857$ & -1.804 & 12.019 & 24,186 \\
\hline $\mathrm{B}_{2} \mathrm{O}_{3}$ & 11.933 & $-36,430$ & $1,863.5$ & -43.246 & $-85,226$ & $4,536.9$ & -211.573 & 291,987 & 1.547 & 10.586 & $-19,423$ \\
\hline $\mathrm{Na}_{2} \mathrm{O}$ & -7.219 & $-5,118$ & 456.9 & -45.074 & $-78,630$ & $4,487.7$ & -214.818 & 295,845 & 11.125 & 11.784 & $-5,986$ \\
\hline $\mathrm{Li}_{2} \mathrm{O}$ & 32.318 & $-104,776$ & $1,072.7$ & -129.375 & 74,808 & $-8,754.2$ & -238.374 & 280,278 & 11.531 & 27.629 & $-15,065$ \\
\hline $\mathrm{Fe}_{2} \mathrm{O}_{3}$ & -9.363 & 4,844 & 676.6 & 38.345 & $-222,993$ & $14,377.0$ & -223.719 & 322,887 & 5.387 & 26.233 & $-44,119$ \\
\hline $\mathrm{Al}_{2} \mathrm{O}_{3}$ & -11.878 & 24,679 & -200.7 & -4.937 & $-130,146$ & $9,301.8$ & -203.868 & 317,733 & 6.075 & -14.764 & $\overline{1}$ \\
\hline $\mathrm{ZrO}_{2}$ & $-43: 309$ & 68,585 & -604.2 &.-21.038 & $-132,882$ & $9,726.1$ & -247.536 & 381,298 & 2.624 & 18.214 & $-31,55$ \\
\hline $\mathrm{Bi}_{2} \mathrm{O}_{3}$ & -8.645 & 6.278 & 380.9 & -19.032 & $-181,576$ & $6,954.1$ & -208.294 & 299,581 & 4.723 & 13.101 & -22.219 \\
\hline $\mathrm{P}_{2} \mathrm{O}_{5}$ & -37.139 & 84,975 & $-2,863.3$ & -17.783 & $-127,610$ & $8,458.3$ & -226.526 & 343,617 & 7.292 & 2.350 & $-6,672$ \\
\hline $\mathrm{UO}_{2}$ & & & & 10.531 & $-173,966$ & $11,736.0$ & -226.904 & 331,927 & & & \\
\hline Others & -10.612 & 2,805 & $1,007.7$ & 148.960 & $-466,297$ & $26,051.0$ & -226.085 & 326,998 & -9.475 & -38.555 & -16.158 \\
\hline$\left(\mathrm{SiO}_{2}\right)^{2}$ & & & & & $-543,812$ & $30,415.0$ & -741.229 & $1,083,012$ & 9.029 & & $-47,64$ \\
\hline$\left(\mathrm{Li}_{2} \mathrm{O}\right)^{2}$ & -406.501 & 643,531 & & 919.751 & $-2,272,467$ & $156,335.0$ & & & & & \\
\hline$\left(\mathrm{Fe}_{2} \mathrm{O}_{3}\right)^{2}$ & & & & -612.256 & $1,008,976$ & $-645,969.0$ & & & & -76.698 & 125,654 \\
\hline$\left(\mathrm{Al}_{2} \mathrm{O}_{3}\right)^{2}$ & & & $4,112.0$ & & & & & & & 86.416 & $-112,1$ \\
\hline$\left(\mathrm{ZrO}_{2}\right)^{2}$ & & & & & & & & & 30.714 & & \\
\hline$\left(\mathrm{Bi}_{2} \mathrm{O}_{3}\right)^{2}$ & & & & & 443,148 & . & & & & & \\
\hline$\left(\mathrm{P}_{2} \mathrm{O}_{3}\right)^{2}$ & 268.887 & $-662,570$ & $34,995.0$ & & & & & & & & \\
\hline (Others) & & & & -796.641 & $1,642,843$ & $-83,843.0$ & & & 47.819 & 180.456 & \\
\hline$R^{2}$ & 0.945 & 0.957 & 0.878 & 0.865 & 0.883 & 0.895 & 0.705 & 0.676 & 0.818 & 0.732 & 0.802 \\
\hline
\end{tabular}

\subsection{Conclusions}

- High temperature glasses for Hanford wastes are low in $\mathrm{B}_{2} \mathrm{O}_{3}$ and $\mathrm{Li}_{2} \mathrm{O}$. Their main flux component is $\mathrm{Na}_{2} \mathrm{O}$, the need for which can be fully covered from Hanford HLW. These glasses can be higher in refractory oxides $\left(\mathrm{Al}_{2} \mathrm{O}_{3}, \mathrm{Fe}_{2} \mathrm{O}_{3}, \mathrm{ZrO}_{2}, \mathrm{CeO}_{2}\right.$, etc.) than lowtemperature glasses without precipitation of crystalline phases in the melter.

- The $\mathrm{T}_{\mathrm{M}}$ of $\mathrm{HLW}$ glasses can be decreased most effectively by $\mathrm{Li}_{2} \mathrm{O}$, followed by $\mathrm{Na}_{2} \mathrm{O}$ and $\mathrm{B}_{2} \mathrm{O}_{3}$. However, the most effective component that decreases $T_{M}$ and $T_{L}$ simultaneously is $\mathrm{Na}_{2} \mathrm{O} . \mathrm{SiO}_{2}, \mathrm{Al}_{2} \mathrm{O}_{3}$, and $\mathrm{P}_{2} \mathrm{O}_{5}$ increase $\mathrm{T}_{\mathrm{M}}$.

- $\mathrm{SiO}_{2}$ addition increases the gap between $\mathrm{T}_{\mathrm{M}}$ and $\mathrm{T}_{\mathrm{L}}$. Therefore, the addition of $\mathrm{SiO}_{2}$ is desirable for increased waste loading. Although $\mathrm{T}_{M}$ increases with increasing $\mathrm{SiO}_{2}$ content, $\mathrm{Na}_{2} \mathrm{O}$ from Hanford $\mathrm{HLW}$ reduces the $\mathrm{T}_{M}$ without effecting the gap between $\mathrm{T}_{M}$ and $T_{L}$. Hence, the $T_{M}$ of high-waste loaded glasses is moderate (approximately $1350^{\circ} \mathrm{C}$ ). 
- Electrical conductivity of high-temperature HLW glasses depends on the concentration of alkaline oxides. The supply of $\mathrm{Na}_{2} \mathrm{O}$ from Hanford $\mathrm{HLW}$ is sufficient for molten glass to conduct electricity.

- Glass viscosity must be predicted accurately because it determines the $T_{M}$. VFT equation fitted to data augmented by low temperature viscosity (such as that at $T_{g}$ ) is adequate for viscosity/temperature correlation over a wide temperature range. First- or second-order coefficients for VFT parameters are sifficient to cover broad composition regions. However, these coefficients differ for low- and high-temperature glasses.

- Glass length is most increased by $\mathrm{ZrO}_{2}$ and decreased by $\mathrm{Li}_{2} \mathrm{O}$. Hence, $\mathrm{ZrO}_{2}$ makes $\mathrm{HLW}$ glass viscosity sensitive to temperature fluctuations, whereas $\mathrm{Li}_{2} \mathrm{O}$ has an opposite effect.

- $T_{8}$ for high-temperature HLW glasses is within 440 and $550^{\circ} \mathrm{C}$. It is lowered by alkaline oxides and $\mathrm{Bi}_{2} \mathrm{O}_{3}$ and raised by $\mathrm{Al}_{2} \mathrm{O}_{3}, \mathrm{ZrO}_{2}, \mathrm{~B}_{2} \mathrm{O}_{3}, \mathrm{Fe}_{2} \mathrm{O}_{3}$, and $\mathrm{SiO}_{2}$.

- Less common components may significantly affect glass properties. $\mathrm{Bi}_{2} \mathrm{O}_{3}$ decreases $\mathrm{T}_{M}$ $T_{g}$, and $T_{L} . P_{2} O_{5}$ decreases $T_{M}$ and $T_{L}$, exhibits and anomalous effect on $T_{g}$, and has a positive effect on glass durability. $\mathrm{UO}_{2}$ decreases $\mathrm{T}_{M}$, makes glass longer, and has little effect on durability. $\mathrm{TiO}_{2}$ decreases $\mathrm{T}_{\mathrm{M}}$ and increases durability. $\mathrm{Cr}_{2} \mathrm{O}_{3}$ increases durability.

- Significant differences were found between averaged and local values of component effects on glass durability. Also, glass components may affect high- and low-temperature glasses differently. For example, $\mathrm{B}_{2} \mathrm{O}_{3}$ increases durability of high-temperature glasses and decreases durability of low-temperature glasses. For other components, the trends are similar but the magnitudes of effects can be different. For example, $\mathrm{SiO}_{2}$ and $\mathrm{Li}_{2} \mathrm{O}$ component effects are significantly different in high- and low-temperature glasses.

- $\quad \mathrm{Al}_{2} \mathrm{O}_{3}$ and $\mathrm{B}_{2} \mathrm{O}_{3}$ exhibit a remarkably nonlinear behavior in their effects on glass durability.

- Canister centerline cooling slightly increases glass durability except when a substantial fraction of glass is crystallized. The durability of a crystallized glass may decrease or, seldomly, increase. None of the high-temperature glasses tested in this study exhibited an unacceptable decrease in durability due to canister centerline cooling.

\subsection{Recommendations}

- A thorough statistically designed testing is needed to cover the full composition region of Hanford high-temperature HIW glasses. Such a study has never been performed. A test plan for this testing was written by Piepel et al. (1995).

- The composition region of low-temperature Hanford HLW glasses should be extended to include the high waste loading subregion. Previous studies (Hrma, Piepel, et al. 1994) focussed on glasses loaded with less than 30 wt\% HLW, while waste loadings up to 65 wt\% are achievable.

- Effects of key minor components, such as $\mathrm{Cr}_{2} \mathrm{O}_{3}, \mathrm{NiO}, \mathrm{CeO}_{2}$, and others (see Piepel et al. 1995) need a study to determine their effect on the maximum waste loading and glass 
properties. This knowledge will reduce the likelihood of production failures, support pretreatment and blending studies, and provide data for glass formulation and melter design and operation.

- Studies that focus on high waste loading glasses are needed. These studies will involve $T_{L}$ testing and modelling. Waste loading maximization will shorten production time and reduce storage space.

- Components and processes that can interfere with steady melting should be identified. A coldcap melting study is needed to avoid production interruptions.

\subsection{References}

BC Bunker. "Waste Glass Leaching: Chemistry and Kinetics," Scientific Basis for Nuclear Waste Management X, Materials Research Society, Pittsburgh, PA (1987).

BC Bunker. "Molecular Mechanisms for Corrosion of Silica and Silicate Glasses," J. NonCrystalline Solids, Vol 179 (1994).

JJ DeYoreo and A Navrotsky, "Energetics of the Charge-Coupled Substitution Si4+ $\rightarrow \mathrm{Na}++\mathrm{T}^{3+}$ in Glasses $\mathrm{NaTO}_{2} \cdot \mathrm{SiO}_{2}(\mathrm{~T}=\mathrm{Al}, \mathrm{Fe}, \mathrm{Ga}, \mathrm{B})$," J. Am..Ceram. Soc., vol 73 [7] pp 2068-72 (1990).

XD Feng, IL Pegg, A Barkatt, PB Mecedo, SJ Cucinell, and S Lai, "Correlation Between Composition Effects on Glass Durability and the Structural Role of the Constituent Oxides," Nuclear Technology, vol 85, pp334-45 (1989).

P Hrma and RJ Robertus, "Waste Glass Design Based on Property Composition Functions," Ceram. Eng. Sci. Proc. 14 [11-12] 187-203 (1993).

P Hrma, GF Piepel, MJ Schweiger, DE Smith, DS Kim, PE Redgate, JD Vienna, CA LoPresti, DB Simpson, DK Peeler, and MH Langowsk, "Property/Composition Relationships for Hanford High-Level Waste Glasses Melting at $1150^{\circ} \mathrm{C}$, " PNL 10359, Vol. 1 and 2, Pacific Northwest Laboratory, Richland, Washington (1994).

P Hrma, GF Piepel, PE Redgate, DE Smith, MJ Schweiger, JD Vienna, and DS Kim, "Prediction of Processing Properties for Nuclear Waste Glasses, "Ceram. Trans. (1995).

PR Hrma and JD Vienna, "Maximization of Hanford Waste Loading, Investigation Plan," PVTDC95-02.01R, Pacific Northwest Laboratory, Richland, Washington (1995)

DS Kim. "PNL Vitrification Technology Development Project, Evaluation and Recommendation of Candidate Glass Systems for LLW Vitrification: Glass Formulation Technical Status Report," PVTD-C94-02.01C, Pacific Northwest Laboratory, Richland, Washington (1994).

KS Kim and P Hrma, "Models for Liquidus Temperature of Nuclear Waste Glasses," Ceram. Trans. 45, 327-337 (1994).

DS Kim and P Hrma, "Development of High-Waste Loaded High-Level Nuclear Waste Glasses for High-Temperature Melter," Ceram. Trans. 45, 39-47 (1994). 
KS Kim and P Hrma, "Durability of Silicate Glasses with High Level of Sodium for LLW vitrification," Emerging Technologies in Hazardous Waste Management (1995).

KS Kim, DK Peeler, and P Hrma, "Effects of Crystallization on the Chemical Durability of Nuclear Waste Glasses," Ceram. Trans. in press (1995).

WC LaCourse and HJ Stevens. "Properties of Silica Glasses Containing Small Amounts of $\mathrm{B}_{2} \mathrm{O}_{3}$, Borate Glasses: Structure, Properties, Applications, eds. LD Pye, VD Frechette, and NJ Kreidl, Plenum Press, NY (1977).

SL Lambert and DS Kim, "Tank Waste Remediation System High-Level Waste Feed Processability Assessment Report," WHC-SP-1143, Westinghouse Hanford Company, Richland, WA (1994).

MH Langowski, JD Vienna, PR Hrma, and GF Piepel, "The Glass Composition Envelope Definition Fiscal Year 1994 Test Plan," PVID-C94-03.01E Rev. 1 Pacific Northwest Laboratory, Richland, Washington (1994).

H Li, MH Langowski, PR Hrma, MJ Schweiger, JD Vienna, and DE Smith, "Minor Component Study for Simulated High-Level Waste Glasses," PVTD-T3C-95-125, Pacific Northwest Laboratory, Richland, Washington (1995).

H Li, "Letter Report - Minor Component Study for Low-Level Radioactive Waste Glasses," . PVTD-C95-02.01B Pacific Northwest Laboratory, Richland, Washington (1995).

L Lee, "Thermal Analysis of DWPF Canister During Poring and Cooldown," DPST-89-269, Westinghouse Savannah River Co., Aiken, SC (1989).

G Malow, JAC Marples and C Sombret, "Thermal and Radiation Effects on Properties of High Level Waste Products." Radioactive Waste Management and Disposal R. Simon and s. Orlowski, editors, Harwood Academic Publishers, Chur, Switzerland (1980).

JE Mendel and JL McElroy, Waste Solidification Program Volume 10. Evaluation of Solidified Waste Products. BNWL - 1666, Pacific Northwest Laboratory, Richland, Washington, pp. 5.7 5.9 (1972).

Mendel, J. E., W. A. Ross, F. P. Roberts, Y. B. Katayama, J. H. Westsik, Jr., R. P. Turcotte, J.W. Wald and D. J. Bradley. 1977. Annual Report on the Characteristics of High-Level Waste Glasses. BNWL - 2252, Pacific Northwest Laboratory, Richland, Washington.

RA Merrill and CC Chapman, "Preliminary Estimates of Cost Savings for Defense High-Level Waste Vitrification Options," Proceedings, 1993 Int. Conf. on Nucl. Waste Mgt and Env. Rem., Vol 3, pp 799-807 (1993).

DK Peeler and P Hirma, "Predicting Liquid Immiscibility in Multicomponent Nuclear Waste Glasses," Ceram. Trans. 45, 219-229 (1994).

GF Piepel, JD Vienna, PE Redgate, and H Li, "Glass Composition Envelope Definition FY95-96 Test Plan for High-Temperature Melter Glass Formulation and Testing," T3C-95-133, Pacific Northwest Laboratory, Richland, WA (1995). 
- GF Piepel, SA Hartley, and PE Redgate, "Updated Durability/Composition Relationships for Hanford High-Level Waste Glasses," T3C-95-126, Rev. 0, Pacific Northwest Laboratory, Richland, WA (1995b).

HD Schreiber and GB Balazs, "The Chemistry of Uranium in Boro-silicate Glasses. Part 1. Simple Base Compositions Relevant to the Immobilization of Nuclear Waste," Phys. and Chem. of Glass. Vol 23, [5] pp 139-46 (1982).

HD Schreiber, BK Kochanowski, and CW Schreiber, "Compositional Dependance of Redox Equilibria in Sodium Silicate Glasses," J. Non-Crystalline Solids, Vol 177 (1994).

M Volf. "Chemical Approach to Glass," Elsevier Press, NY (1984).

\subsection{Raw Data}

10.1 All-Blend Waste Simulant Composition

\begin{tabular}{|r|r|}
\hline \multicolumn{2}{|c|}{ All Blend Waste Simulant } \\
\hline SiO2 & 0.1237 \\
B2O3 & 0.0009 \\
Na2O & 0.2467 \\
Li2O & 0.0000 \\
CaO & 0.0252 \\
MgO & 0.0009 \\
Fe2O3 & 0.1360 \\
Al2O3 & 0.0974 \\
ZrO2 & 0.0875 \\
Bi2O3 & 0.0275 \\
P2O5 & 0.0159 \\
Others & 0.2383 \\
\hline Total & 1.0000 \\
\hline
\end{tabular}

\begin{tabular}{|r|r|}
\hline Others For All Blend Waste \\
\hline $\mathrm{CdO}$ & 0.1124 \\
$\mathrm{CeO} 2$ & 3.3785 \\
$\mathrm{Cr} 2 \mathrm{O3}$ & 1.0587 \\
$\mathrm{~F}$ & 0.6791 \\
$\mathrm{~K} 2 \mathrm{O}$ & 0.2625 \\
$\mathrm{La2O3}$ & 0.5290 \\
$\mathrm{MnO2}$ & 2.2451 \\
$\mathrm{MoO3}$ & 0.0910 \\
$\mathrm{Nd2O3}$ & 12.0422 \\
$\mathrm{NiO}$ & 2.8070 \\
SO3 & 0.4083 \\
WO3 & 0.2149 \\
\hline Total & 23.8287 \\
\hline
\end{tabular}


10.2 Viscosity Temperature Table

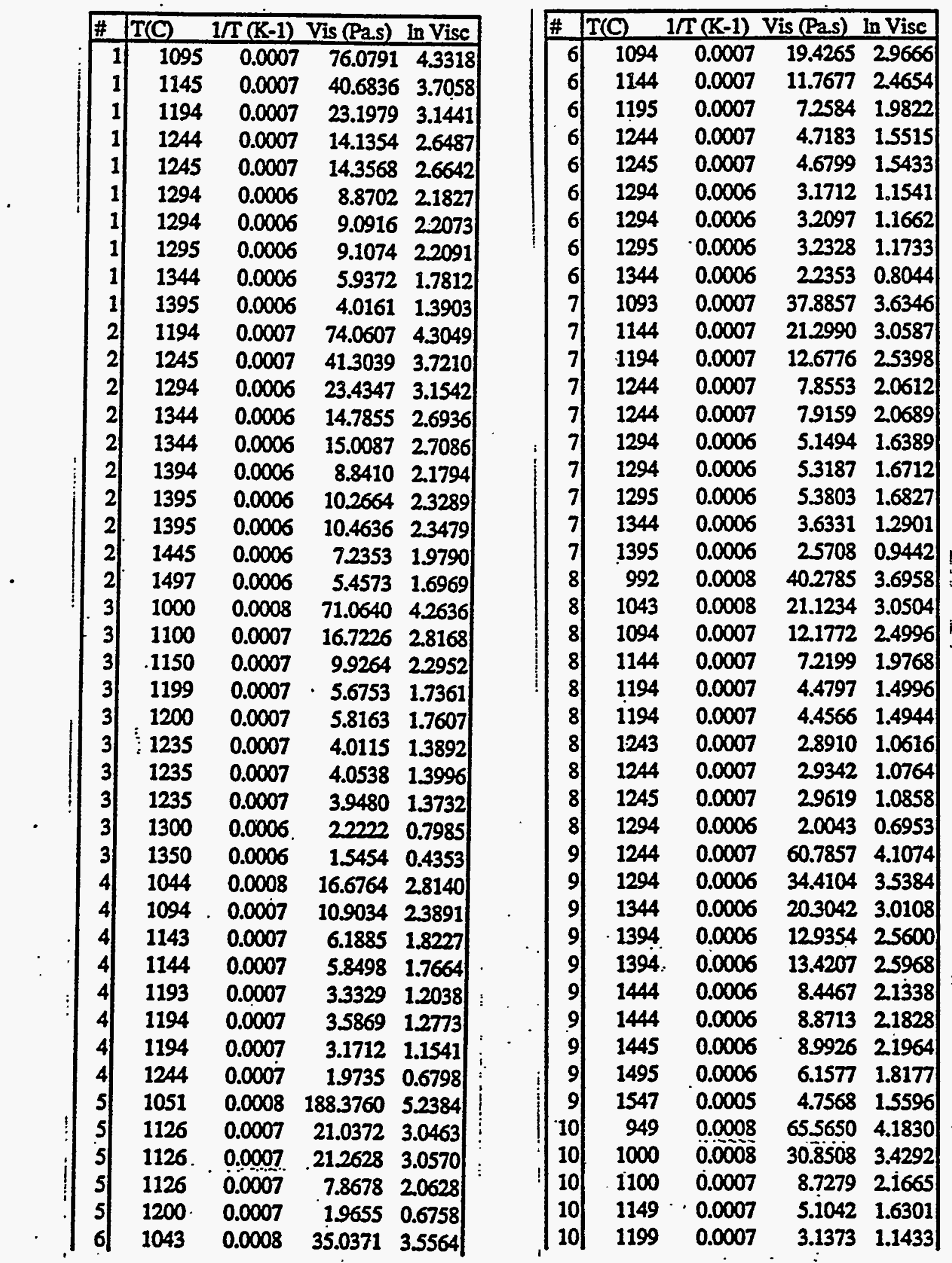




\begin{tabular}{|r|rrrr|}
\hline$\#$ & $T(C)$ & $1 / T(K-1)$ & Vis (Pa.s) & In Visc \\
\hline 10 & 1199 & 0.0007 & 3.2430 & 1.1765 \\
10 & 1249 & 0.0007 & 2.1347 & 0.7583 \\
10 & 1249 & 0.0007 & 2.1770 & 0.7780 \\
10 & 1249 & 0.0007 & 2.2334 & 0.8035 \\
10 & 1299 & 0.0006 & 1.5143 & 0.4150 \\
11 & 992 & 0.0008 & 93.9034 & 4.5423 \\
11 & 1042 & 0.0008 & 46.1465 & 3.8318 \\
11 & 1094 & 0.0007 & 24.9268 & 3.2159 \\
11 & 1143 & 0.0007 & 14.3002 & 2.6603 \\
11 & 1193 & 0.0007 & 8.5528 & 2.1463 \\
11 & 1193 & 0.0007 & 8.6135 & 2.1533 \\
11 & 1243 & 0.0007 & 5.5342 & 1.7110 \\
11 & 1243 & 0.0007 & 5.6574 & 1.7330 \\
11 & 1244 & 0.0007 & 5.7113 & 1.7424 \\
11 & 1294 & 0.0006 & 3.7254 & 1.3152 \\
11 & 1344 & 0.0006 & 2.5585 & 0.9394 \\
12 & 1245 & 0.0007 & 92.0868 & 4.5227 \\
12 & 1294 & 0.0006 & 49.1659 & 3.8952 \\
12 & 1344 & 0.0006 & 27.7062 & 3.3217 \\
12 & 1394 & 0.0006 & 16.5886 & 2.8087 \\
12 & 1394 & 0.0006 & 17.2323 & 2.8468 \\
12 & 1444 & 0.0006 & 10.6607 & 2.3666 \\
12 & 1445 & 0.0006 & 11.2218 & 2.4179 \\
12 & 1446 & 0.0006 & 11.1157 & 2.4084 \\
12 & 1496 & 0.0006 & 7.9159 & 2.0689 \\
12 & 1547 & 0.0005 & 5.5112 & 1.7068 \\
13 & 1093 & 0.0007 & 42.9927 & 3.7610 \\
13 & 1144 & 0.0007 & 22.9662 & 3.1340 \\
13 & 1194 & 0.0007 & 18.4786 & 2.9166 \\
13 & 1244 & 0.0007 & 10.3769 & 2.3396 \\
13 & 1244 & 0.0007 & 10.6931 & 2.3696 \\
13 & 1294 & 0.0006 & 5.8297 & 1.7630 \\
13 & 1294 & 0.0006 & 5.9205 & 1.7784 \\
13 & 1295 & 0.0006 & 5.1114 & 1.6315 \\
13 & 1344 & 0.0006 & 3.5689 & 1.2723 \\
13 & 1396 & 0.0006 & 22744 & 0.8217 \\
14 & 1093 & 0.0007 & 59.3883 & 4.0841 \\
14 & 1144 & 0.0007 & 30.6504 & 3.4226 \\
14 & 1195 & 0.0007 & 18.6366 & 2.9251 \\
14 & 1244 & 0.0007 & 11.3583 & 2.4299 \\
14 & 1245 & 0.0007 & 10.9792 & 2.3960 \\
14 & 1294 & 0.0006 & 7.0121 & 1.9476 \\
14 & 1295 & 0.0006 & 6.7658 & 1.9119 \\
14 & 1295 & 0.0006 & 7.0583 & 1.9542
\end{tabular}

\begin{tabular}{|r|rrrr|}
\hline$\#$ & $\mathrm{~T}(\mathrm{C})$ & $1 \mathrm{~T}(\mathrm{~K}-1)$ & Vis (Pa.s) & In Visc \\
\hline 14 & 1345 & 0.0006 & 4.5182 & 1.5081 \\
14 & 1395 & 0.0006 & 3.1635 & 1.1517 \\
15 & 1143 & 0.0007 & 66.7944 & 4.2016 \\
15 & 1194 & 0.0007 & 36.8032 & 3.6056 \\
15 & 1244 & 0.0007 & 21.6208 & 3.0737 \\
15 & 1294 & 0.0006 & 13.7240 & 2.6191 \\
15 & 1294 & 0.0006 & 13.8908 & 2.6312 \\
15 & 1343 & 0.0006 & 8.6742 & 2.1603 \\
15 & 1344 & 0.0006 & 8.9320 & 2.1896 \\
15 & 1345 & 0.0006 & 8.9471 & 2.1913 \\
15 & 1394 & 0.0006 & 6.1038 & 1.8089 \\
15 & 1445 & 0.0006 & 4.1334 & 1.4191 \\
16 & 1244 & 0.0007 & 120.4377 & 4.7911 \\
16 & 1295 & 0.0006 & 45.9162 & 3.8268 \\
16 & 1345 & 0.0006 & 38.7508 & 3.6572 \\
16 & 1395 & 0.0006 & 18.5079 & 2.9182 \\
16 & 1395 & 0.0006 & 20.4731 & 3.0191 \\
16 & 1445 & 0.0006 & 9.5335 & 2.2548 \\
16 & 1445 & 0.0006 & 10.1660 & 2.3190 \\
16 & 1446 & 0.0006 & 8.7654 & 2.1708 \\
16 & 1496 & 0.0006 & 5.6558 & 1.7327 \\
16 & 1547 & 0.0005 & 4.1209 & 1.4161 \\
17 & 1245 & 0.0007 & 60.5062 & 4.1027 \\
17 & 1295 & 0.0006 & 32.0746 & 3.4681 \\
17 & 1345 & 0.0006 & 19.9239 & 2.9919 \\
17 & 1395 & 0.0006 & 12.0559 & 2.4896 \\
17 & 1395 & 0.0006 & 12.3743 & 2.5156 \\
17 & 1444 & 0.0005 & 7.5355 & 2.0196 \\
17 & 1445 & 0.0006 & 7.4913 & 2.0137 \\
17 & 1446 & 0.0006 & 7.4307 & 2.0056 \\
17 & 1496 & 0.0006 & 5.0570 & 1.6208 \\
17 & 1547 & 0.0005 & 4.2873 & 1.4557 \\
18 & 1194 & 0.0007 & 61.9796 & 4.1268 \\
18 & 1245 & 0.0007 & 339929 & 3.5262 \\
18 & 1294 & 0.0006 & 19.2999 & 2.9601 \\
18 & 1344 & 0.0006 & 12.0335 & 2.4877 \\
18 & 1344 & 0.0006 & 12.2896 & 2.5088 \\
18 & 1394 & 0.0006 & 7.6358 & 2.0328 \\
18 & 1395 & 0.0006 & 7.8165 & 2.0562 \\
18 & 1396 & 0.0006 & 8.0123 & 2.0810 \\
18 & 1446 & 0.0006 & 5.2551 & 1.6592 \\
18 & 1496 & 0.0006 & 4.0831 & 1.4069 \\
19 & 1095 & 0.0007 & 42.1135 & 3.7404 \\
\hline & 1145 & 0.0007 & 23.3818 & 3.1520 \\
\hline & & & & \\
\hline
\end{tabular}




\begin{tabular}{|c|c|c|c|c|}
\hline \# & $T(C)$ & $1 / \mathrm{T}(\mathrm{K}-1)$ & Vis (Pas) & In Visc \\
\hline 19 & 1194 & 0.0007 & 13.6049 & 2.6104 \\
\hline 19 & 1244 & 0.0007 & 85366 & 2.1444 \\
\hline 19 & 1244 & 0.0007 & 8.6131 & 2.1533 \\
\hline 19 & 1294 & 0.0006 & 5.5339 & 1.7109 \\
\hline 19 & 1294. & 0.0006 & 5.6508 & 1.7318 \\
\hline 19 & 1295 & 0.0006 & 5.6451 & 1.7308 \\
\hline 19 & 1345 & 0.0006 & 3.8140 & 1.3387 \\
\hline 19 & 1395 & 0.0006 & 2.6561 & 0.9769 \\
\hline $20 \mid$ & 1194 & 0.0007 & 94.2372 & 4.5458 \\
\hline $20 \mid$ & 1245 & 0.0007 & 35.8273 & 3.5787 \\
\hline $20 \mid$ & 1295 & 0.0006 & 80.0100 & 4.3822 \\
\hline $20 \mid$ & 1345 & 0.0006 & 24.3155 & 3.1911 \\
\hline $20 \mid$ & 1345 & 0.0006 & 23.2009 & 3.1442 \\
\hline 20 & 1395 & 0.0006 & 11.6871 & 24585 \\
\hline$|20|$ & 1395 & 0.0006 & 10.3467 & 2.3367 \\
\hline $20 \mid$ & 1396 & 0.0006 & 5.7466 & 1.7486 \\
\hline $20 \mid$ & 1446 & 0.0006 & 5.1643 & 1.6418 \\
\hline$|20|$ & 1496 & 0.0006 & 2.3818 & 0.8679 \\
\hline 21 & 1144 & 0.0007 & 73.1078 & 4.2919 \\
\hline |21 & 1195 & 0.0007 & 32.1586 & 3.4707 \\
\hline $21 \mid$ & 1245 & 0.0007 & 21.5584 & 3.0708 \\
\hline 21 & 1294 & 0.0006 & 12.4402 & 25209 \\
\hline $21 \mid$ & 1295 & 0.0006 & 11.8829 & 2.4751 \\
\hline 21 & 1344 & 0.0005 & 6.7220 & 1.9054 \\
\hline 21 & 1345 & 0.0006 & $\cdot 7.1756$ & 1.9707 \\
\hline 21 & 1346 & 0.0006 & 6.1095 & 1.8098 \\
\hline 21 & 1395 & .0 .0006 & 4.1889 & 1.4324 \\
\hline 21 & 1446 & 0.0006 & 2.5708 & 0.9442 \\
\hline 22 & 1094 & 0.0007 & 106.8989 & 4.6719 \\
\hline 22 & .1144 & 0.0007 & 51.7866 & 39471 \\
\hline 22 & 1195 & 0.0007 & 27.5892 & 3.3174 \\
\hline 22 & 1244 & 0.0007 & 15.0965 & 2.7145 \\
\hline 22 & 1294 & 0.0006 & 9.2201 & 22214 \\
\hline 22 & 1295 & 0.0006 & 9.4172 & 22425 \\
\hline 22 & 1344 & 0.0006 & 59037 & 1.7756 \\
\hline 22 & 1345 & 0.0006 & 6.0961 & 1.8077 \\
\hline 22 & $1345^{\circ}$ & 0.0006 & 6.1269 & 1.8127 \\
\hline 22 & 1395 & 0.0006 & 3.9640 & 1.3773 \\
\hline 22 & 1446 & 0.0006 & 2.7156 & 0.9990 \\
\hline $23 \mid$ & 1144 & 0.0007 & 30.2516 & 3.4095 \\
\hline 23 & 1194: & 0.0007 & 18.5781 & 2.9220 \\
\hline 23 & 1244 & 0.0007 & 11.6464 & 2.4550 \\
\hline 23 & 1294 & 0.0006 & 7.5975 & 2.0278 \\
\hline $23 \mid$ & 1294 & 0.0006 & 7.7946 & 2.0534 \\
\hline
\end{tabular}

\begin{tabular}{|l|rrrrr|}
\hline$\#$ & $\mathrm{~T}(\mathrm{C})$ & $1 / \mathrm{T}(\mathrm{K}-1)$ & Vis (Pa.s) & In Visc \\
\hline 23 & 1344 & 0.0006 & 5.2110 & 1.6508 \\
23 & 1345 & 0.0006 & 5.4496 & 1.6955 \\
23 & 1345 & 0.0006 & 5.5727 & 1.7179 \\
23 & 1396 & 0.0006 & 3.8101 & 1.3377 \\
23 & 1446 & 0.0005 & 2.7525 & 1.0125 \\
24 & 1093 & 0.0007 & 54.8630 & 4.0048 \\
24 & 1144 & 0.0007 & 29.0552 & 3.3692 \\
24 & 1194 & 0.0007 & 17.3785 & 2.8552 \\
24 & 1244 & 0.0007 & 10.3726 & 2.3392 \\
24 & 1244 & 0.0007 & 10.6152 & 2.3623 \\
24 & 1294 & 0.0006 & 6.3655 & 1.8509 \\
24 & 1295 & 0.0006 & 6.5503 & 1.8795 \\
24 & 1295 & 0.0006 & 6.3732 & 1.8521 \\
24 & 1345 & 0.0006 & 4.1257 & 1.4172 \\
24 & 1396 & 0.0006 & 2.7741 & 1.0203 \\
25 & 1193 & 0.0007 & 33.2710 & 3.5047 \\
25 & 1244 & 0.0007 & 19.9239 & 2.9919 \\
25 & 1293 & 0.0006 & 12.7383 & 2.5446 \\
25 & 1343 & 0.0006 & 8.1889 & 2.1028 \\
25 & 1344 & 0.0006 & 8.2799 & 2.1138 \\
25 & 1393 & 0.0006 & 5.6497 & 1.7316 \\
25 & 1394 & 0.0006 & 5.7267 & 1.7451 \\
25 & 1394 & 0.0006 & 5.6728 & 1.7357 \\
25 & 1444 & 0.0006 & 3.9025 & 1.3616 \\
25 & 1495 & 0.0006 & 2.9126 & 1.0690 \\
\hline 27 & 1094 & 0.0007 & 43.4119 & 3.7707 \\
27 & 1144 & 0.0007 & 23.0251 & 3.1366 \\
27 & 1195 & 0.0007 & 16.4131 & 2.7981 \\
27 & 1244 & 0.0007 & 9.7660 & 2.2789 \\
27 & 1245 & 0.0007 & 9.4476 & 2.2458 \\
27 & 1295 & 0.0006 & 5.5189 & 1.7082 \\
27 & 1295 & 0.0006 & 5.7190 & 1.7438 \\
27 & 1296 & 0.0006 & 5.2648 & 1.6611 \\
27 & 1345 & 0.0006 & 3.5946 & 1.2794 \\
27 & 1396 & 0.0006 & 2.3676 & 0.8619 \\
28 & 1093 & 0.0007 & 63.9517 & 4.1581 \\
28 & 1144 & 0.0007 & 33.5343 & 3.5126 \\
28 & 1194 & 0.0007 & 19.1532 & 2.9525 \\
28 & 1244 & 0.0007 & 11.9281 & 2.4789 \\
28 & 1244 & 0.0007 & 12.0335 & 2.4877 \\
28 & 1293 & 0.0006 & 7.6358 & 2.0328 \\
28 & 1294 & 0.0006 & 7.6509 & 2.0348 \\
28 & 1295 & 0.0006 & 7.6057 & 2.0289 \\
& 1344 & 0.0006 & 5.2702 & 1.6621 \\
\hline & & & & \\
\hline
\end{tabular}




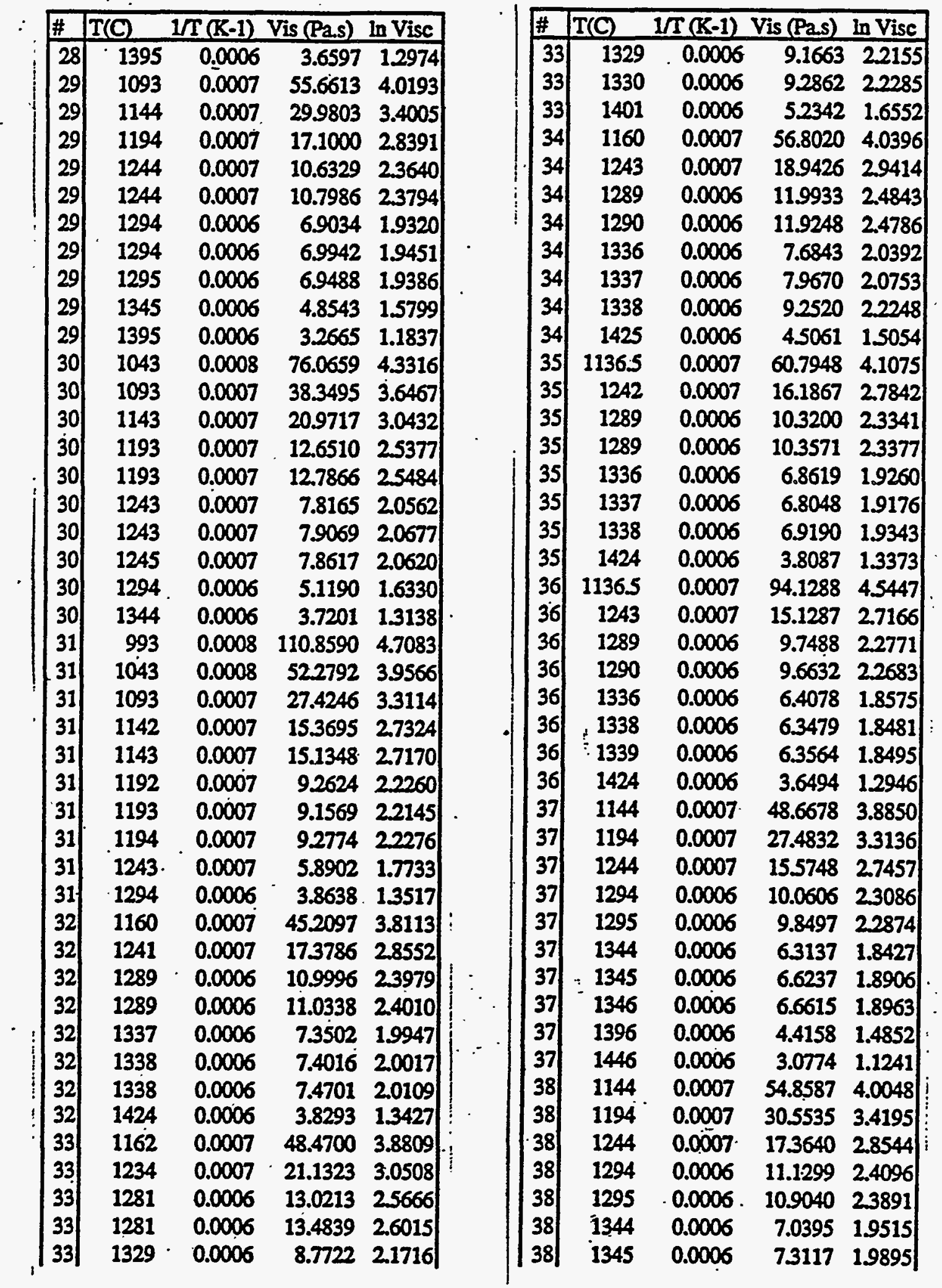




\begin{tabular}{|c|c|c|c|c|}
\hline$\#$ & T(C) & $1 / \mathrm{T}(\mathrm{K}-1)$ & Vis (Pas) & In Vise \\
\hline 38 & 1346 & 0.0006 & 7.3269 & 19915 \\
\hline 38 & 1396 & 0.0006 & 4.8619 & 1.5814 \\
\hline 38 & 1446 & 0.0006 & 3.3421 & 12066 \\
\hline 39 & 1144 & 0.0007 & 66.2050 & 4.1928 \\
\hline 39 & 1194 & 0.0007 & 35.4260 & 3.5674 \\
\hline 39 & 1244 & 0.0007 & 20.0920 & 3.0003 \\
\hline 39 & 1294 & 0.0006 & 12.4400 & 25209 \\
\hline 39 & 1294 & 0.0006 & 12.6360 & 2.5365 \\
\hline 39 & 1344 & 0.0006 & 7.9220 & 2.0696 \\
\hline 39 & 1344 & 0.0006 & 8.0880 & 2.0904 \\
\hline $39 \mid$ & 1345 & 0.0006 & 8.0270 & 2.0828 \\
\hline 39 & 1396 & 0.0006 & 5.4590 & 1.6973 \\
\hline 39 & 1446 & 0.0006 & 4.0000 & 1.3863 \\
\hline 40 & 1194 & 0.0007 & 42.0180 & - 3.7381 \\
\hline 40 & 1245 & 0.0007 & 23.0540 & 3.1378 \\
\hline 40 & 1295 & 0.0006 & 14.0670 & 2.6438 \\
\hline 40 & 1295 & 0.0006 & 14.1720 & 2.6513 \\
\hline $40 \mid$ & 1344 & 0.0006 & 8.7200 & 21656 \\
\hline 40 & 1345 & 0.0006 & 8.9160 & 2.1878 \\
\hline 40 & 1346 & 0.0006 & 8.9910 & 2.1962 \\
\hline$|40|$ & 1396 & 0.0006 & 5.9810 & 1.7886 \\
\hline 40 & 1447 & 0.0006 & 4.0230 & 1.3920 \\
\hline
\end{tabular}


10.3 Electrical Conductivity Temperature Table

\begin{tabular}{|c|c|c|c|c|c|c|}
\hline \# & Glass & $\mathrm{T}(\mathrm{C})$ & EC 100 & EC 1000 & EC 10000 & EC 100000 \\
\hline 1 & CVS3-1 & 1446 & 58.839 & 58.635 & 61.227 & 61.598 \\
\hline 1 & |CVS3-1 & 1347 & 42.299 & 45549 & 47.137 & 47.371 \\
\hline 1 & CVS3-1 & 1248 & 30.185 & 33.709 & 34.275 & 34.451 \\
\hline 1 & CVS3-1 & 1148 & 21.193 & 23.077 & 23.740 & 23.909 \\
\hline 2 & CVS3-2 & 1498 & 41.130 & 49.205 & 50.125 & 49.991 \\
\hline 2 & CVS3-2 & 1397 & 31.511 & 31.728 & 32.265 & 32.287 \\
\hline 2 & CVS3-2 & 1297 & 22.372 & 23.928 & 24.481 & 24.586 \\
\hline 2 & CVS3-2 & 1197 & 15.610 & 17275 & 17.681 & 17.712 \\
\hline 3 & CVS3-3 & 1345 & 66.047 & 67.954 & 70.228 & 70.297 \\
\hline 3 & CVS3-3 & 1247 & 46297 & 51.069 & 52.301 & 52.305 \\
\hline 3 & CVS3.3 & 1148. & 33.031 & 36.117 & 37.079 & 37.101 \\
\hline 3 & CVS3-3 & 1048 & 21231 & 23.652 & 24.140 & 24.215 \\
\hline 4 & CVS3-4 & 1245 & 58.410 & 63.098 & 64.412 & 64.249 \\
\hline 4 & CVS3-4 & 1147 & 42591 & 46.130 & 47.640 & 47.606 \\
\hline 4 & CVS3-4 & 1048 & 28.218 & 31.369 & 32.066 & 32.233 \\
\hline 4 & CVS3 4 & 949 & $16.960^{\circ}$ & 18.962 & 19.712 & 19.850 \\
\hline 5 & CVS3-5 & 1196 & 58.745 & 65.783 & 67.860 & 67.663 \\
\hline 5 & CVS3-5 & 1147 & 50.372 & 56.207 & 58.342 & 58.308 \\
\hline 5 & CVS3-5 & 1098 & 42.255 & 47.415 & 49.334 & 49.375 \\
\hline 5 & CVS3-5 & 1048 & 34.327 & 39.007 & 40.528 & 40.713 \\
\hline 6 & CVS3-6 & 1346 & 38.332 & 40.851 & 42.264 & 42.084 \\
\hline 6 & CVS3-6 & 1248 & 27.857 & 30.335 & 31.508 & 31593 \\
\hline 이 & CVS3-6 & 1148 & 19.661 & 21.552 & 22.052 & 22.033 \\
\hline 6 & CVS3-6 & 1048 & 12.627 & 13.659 & .14 .046 & 14.049 \\
\hline 7) & CVS3-7 & 1396 & 42.199 & 48.591 & 49.098 & 49.110 \\
\hline 7) & CVS3-7 & 1297 & 33.535 & 36.772 & 37.711 & 37.917 \\
\hline 7 & CVS3-7 & 1198 & 23.825 & 27.595 & 27219 & 27.355 \\
\hline$\pi$ & CVS3-7 & 1098 & 16.085 & 17.790 & 18.436 & 18.305 \\
\hline 8 & CVS3-8 & 1296 & 74.159 & 91.831 & 98.824 & 97.881 \\
\hline 8 & CVS3-8 & 1197 & 58.460 & 72.097 & 77.729 & 77.447 \\
\hline 8 & Cvs3-8 & 1098 & 42.922 & 54.208 & 57.539 & 57.403 \\
\hline 1 & CVS3-8 & 998 & 29.715 . & 37.302 & 39.673 & 39.739 \\
\hline 9 & CVS3-9 & 1549 & 36.134 & 36.616 & 37.287 & 37.184 \\
\hline 9 & CVS3-9 & 1448 & 30.280 & 25.757 & 26.194 & 26.166 \\
\hline 9 & CVS3-9 & 1347 & 18.237 & 18.815 & 19.138 & 19.146 \\
\hline 9 & Civs3-9 & 1247 & 12970 & 13.410 & 13.555 & 13.587 \\
\hline 10 & CVS3-10 & 1295 & 75.783 & 85.833 & 88.874 & 88.510 \\
\hline 10 & CVS3-10 & 1197 & 55.733 & 63.102 & 65.943 & 65.814 \\
\hline 10 & CVS3-10 & 1098 & 38.889 & 44.463 & 46.073 & 46.073 \\
\hline 10 & CVS3-10 & 999 & 24.675 & 28.162 & 29.379 & 29.433 \\
\hline 11 & CVS3-11 & 1346 & 59.163 & 65.550 & 67.329 & 67.231 \\
\hline 11 & CVS3-11 & 1247 & 45.767 & 50.846 & 52.210 & 52.299 \\
\hline 11 & CVS3-11 & 1147 & 32.743 & 36.656 & 37.552 & 37.655 \\
\hline 11 & CVS3-11 & 1047 & 21568 & 24.101 & 24.782 & 24.842 \\
\hline
\end{tabular}




\begin{tabular}{|c|c|c|c|c|c|c|}
\hline$\#$ & Glass & $\mathrm{T}\left({ }^{\circ} \mathrm{C}\right)$ & EC 100 & EC 1000 & EC 10000 & EC 100000 \\
\hline 12 & CVS3-12 & 1549 & 39.250 & 41.443 & 41.960 & 41.961 \\
\hline 12 & CVS3-12 & 1448 & 26.587 & 31.942 & 32.135 & 32.180 \\
\hline 12 & CVS3-12 & 1348 & 22.565 & 24.267 & 24.711 & 24.785 \\
\hline 12 & CVS3-12 & 1248 & 17.189 & 18.099 & 18.482 & 18.495 \\
\hline 13 & CVS3-13 & 1397 & 45.722 & 49.360 & 49.983 & 49.874 \\
\hline 13 & CVS3-13 & 1299 & 37.091 & 37.974 & 38.401 & 38.367 \\
\hline 13 & CVS3-13 & 1199 & 26.304 & 27.687 & 27.854 & 27.878 \\
\hline 13 & CVS3-13 & 1099 & 17.827 & 18.596 & 18.707 & 18.751 \\
\hline 14 & CVS3-14 & 1397 & 47.030 & 51.649 & 52.996 & 53.327 \\
\hline 14 & CVS3-14 & 1298 & 35.745 & 39.397 & $40: 317$ & 40.495 \\
\hline 14 & CVS3-14 & 1198 & 25.613 & 28.398 & 28.806 & 28.974 \\
\hline 14 & CVS3-14 & 1098 & 17.243 & 18.624 & 19.169 & 19.224 \\
\hline 15 & CVS3-15 & 1447 & 46.878 & 53.877 & 58.238 & 57.528 \\
\hline 15 & CVS3-15 & 1347 & 35.415 & 43.002 & 46.493 & 45.963 \\
\hline 15 & CVS3-15 & 1248 & 26.957 & 32.986 & 34.870 & 34.589 \\
\hline 15 & CVS3-15 & 1147 & 19.469 & 23.367 & 24.528 & 24.487 \\
\hline 16 & CVS3-16 & 1551 & 47.101 & 43.811 & 43.544 & 43.757 \\
\hline 16 & CVS3-16 & 1451 & 31.869 & 32.096 & 32.496 & 32.558 \\
\hline 16 & CVS3-16 & 1350 & 23.489 & 24.413 & 24.700 & 24.780 \\
\hline 16 & CVS3-16 & 1250 & 16.559 & 17.643 & 18.123 & 18.306 \\
\hline 17 & CVS3-17 & 1498 & 36.839 & 45.005 & 45.895 & 45.823 \\
\hline 17 & CVS3-17 & 1398 & 33.266 & 35.953 & 36.566 & 36.587 \\
\hline 17 & CVS3-17 & 1298 & 25.433 & 27.077 & 27.734 & 27.821 \\
\hline 17 & CVS3-17 & 1198 & 17.684 & 19.459 & ! 20.068 & 20.155 \\
\hline 18 & CVS3-18 & 1498 & 48.170 & 54.964 & 56.412 & 56.082 \\
\hline 18 & CVS3-18 & $1398^{\circ}$ & 37.375 & 42.653 & 43.713 & 43.489 \\
\hline 18 & CVS3-18 & 1298 & 28.573 & 31.810 & 32.645 & 32.547 \\
\hline 18 & CVS3-18 & 1198 & 20.086 & 22.703 & 23.353 & 23.342 \\
\hline 19 & CVS3-19 & 1446 & 56.386 & 93.303 & 122322 & 132.552 \\
\hline 19 & CVS3-19 & 1347 & 48.658 & 67.157 & 81.274 & 86.044 \\
\hline 19 & CVS3-19 & 1248 & 35.484 & 46.327 & 52.873 & 54.838 \\
\hline 19 & CVS3-19 & 1148 & 25.055 & 30.991 & 33.935 & 34.724 \\
\hline 20 & CVS3-20 & 1499 & 52.059 & 66.608 & 68.290 & 68.578 \\
\hline 20 & CVS3-20 & 1399 & 39.319 & 48.100 & 49.060 & 49.425 \\
\hline 20 & CVS3-20 & 1299 & 30.591 & 34.688 & 35.693 & 35.948 \\
\hline 20 & CVS3-20 & 1200 & 21.441 & 24.241 & 24.716 & 24.834 \\
\hline 21 & CVS3-21 & 1448 & 47.818 & 63.684 & 70.264 & 64.544 \\
\hline 21 & CVS3-21 & 1349 & 35.481 & 46.785 & 50.282 & 47.408 \\
\hline 21 & CVS3-21 & 1250 & 26.518 & 32.324 & 34.103 & 32.837| \\
\hline 21 & CVS3-21 & 1149 & 17.755 & 20.935 & 21.986 & 21.483 \\
\hline 22 & CVS3-22 & 1446 & 37.442 & 41.619 & 43229 & 42.662 \\
\hline 22 & CVS3-22 & 1347 & 28.045 & 31.814 & 32.819 & 32.560 \\
\hline 22 & CVS3-22 & 1247 & 20.747 & 22.952 & 23.766 & 23.627 \\
\hline-1 & CVS3-22 & 1147 & 14.154 & 15.607 & 16.089 & 16.067 \\
\hline
\end{tabular}


PVTD-C95-02.01E/J

\begin{tabular}{|c|c|c|c|c|c|c|}
\hline \# & Glass & $\mathrm{T}(\mathrm{C})$ & EC 100 & EC 1000 & EC 10000 & EC 100000 \\
\hline 23 & CVS3-23 & 1447 & 52988 & 63.049 & 64.761 & 65.078 \\
\hline 23 & CVS3-23 & 1348 & 46.321 & 50.631 & 52.104 & 52.389 \\
\hline 23 & CVS3-23 & 1248 & 34.649 & 38.432 & 39.595 & 39.739 \\
\hline 23 & CVS3-23 & 1148 & 24.733 & 27.238 & 28.139 & 28.237 \\
\hline 24 & CVS3-24 & 1396 & 44204 & 46.842 & 47.848 & 47.862 \\
\hline 24 & CVS3-24 & 1298 & 32.963 & 35.725 & 36.523 & 36.555 \\
\hline 24 & CVS3-24 & 1198 & 23.744 & 25.609 & 26242 & 26.244 \\
\hline 24 & CVS3-24 & 1098 & 15.559 & 17.089 & 17.416 & 17.486 \\
\hline 25 & CVS3-25 & 1497 & 53.918 & 81.934 & 115.024 & 103.001 \\
\hline 25 & CVS3-25 & 1397 & 44.458 & 63.409 & 81.983 & 76.003 \\
\hline 25 & CVS3-25 & 1297 & 35.335 & 46.507 & 56.852 & 54.108 \\
\hline 25 & CVS3-25 & 1197 & 26.113 & 33.046 & 38.365 & 37.038 \\
\hline 27 & CVS3-27 & 1397 & 48.228 & 49.461 & 50.689 & 50.595 \\
\hline 27 & CVS3-27 & 1298 & 36.256 & 38.009 & 38.619 & 38.542 \\
\hline 27 & CVS3-27 & 1198 & 26.203 & 27261 & 27.786 & 27.725 \\
\hline 27 & CVS3-27 & 1098 & 17.379 & 18.310 & 18.501 & 18.517 \\
\hline 28 & CVS3-28 & 1396 & 44.340 & 50.104 & 51.912 & 51.801 \\
\hline 28 & CVS3-28 & 1297. & 32.767 & 36.822 & 38.062 & 38.082 \\
\hline 28 & CVS3-28 & 1198 & 23.812 & 26.269 & 27.117 & 27.219 \\
\hline 28 & CVS3-28 & 1098 & 15.812 & 17.591 & 18.110 & 18.148 \\
\hline 29 & CVS3-29 & 1396 & 44.562 & 47.509 & 48.314 & 48.609 \\
\hline 29 & CVS3-29 & 1298 & 34.557 & 36.467 & 37.218 & 37.351 \\
\hline 29 & CVS3-29 & 1198 & 25.052 & 26.601 & 27.320 & 27.419 \\
\hline 29 & CVS3-29 & 1098 & 16.678 & 18.003 & 18.376 & 18.401 \\
\hline 30 & CVS3-30 & 1346 & 38.949 & 42.141 & 43.419 & 43.408 \\
\hline 30 & CVS3-30 & 1247 & 29.131 & 31.766 & 32.343 & 32.478 \\
\hline 30 & CVS3-30 & 1148 & 20.358 & 22.068 & 22.528 & 22.523 \\
\hline 30 & CVS3-30 & 1048 & 12.967 & 14.037 & 14.308 & 14.321 \\
\hline 31 & CVS3-31 & 1296 & 33.686 & 37.293 & 38.323 & 38.351 \\
\hline 31 & CVS3-31 & 1198 & 24.414 & 26933 & 27.417 & 27.521 \\
\hline 31 & CVS3-31 & 1098 & 16.336 & 17.801 & 18.122 & 18.113 \\
\hline 31 & CVS3-31 & 998 & 9.757 & 10.502 & 10.705 & 10.726 \\
\hline 37 & CंVS3-37 & 1449 & 53.487 & 58.628 & 59.281 & 59.497 \\
\hline 37 & CVS3-37 & 1350 & 41.917 & 46.333 & 47.239 & 47.275 \\
\hline 37| & CVS3-37 & 1251 & 31.266 & 34.424 & 35.326 & 35.384 \\
\hline 37 & CVS3-37 & 1150 & 21.968 & 24.116 & 24.896 & 24.983 \\
\hline 38 & CVS3-38 & 1449 & 54.246 & 58.375 & 59.777 & 59.469 \\
\hline 38 & CVS3-38 & 1350 & 41.521 & 46.599 & 47.321 & 47.150 \\
\hline 38 & CVS3-38. & 1250 & 31.166 & 34.887 & 35.604 & 35.572 \\
\hline 38 & CVS3-38 & 1150 & 22.204 & 24.513 & 25.257 & 25.255 \\
\hline 39 & CVS3-39 & 1448 & 42.350 & 49.297 & 48.888 & 48.859 \\
\hline 39 & CVS3-39 & 1350 & 34.345 & 36.203 & 37.027 & 37.067 \\
\hline 39 & CVS3-39 & 1250 & 25.829 & 27.697 & 28.271 & 28.333 \\
\hline $39 \mid$ & CVS3-39 & 1150 & 18.296 & 19.883 & 20.326 & 20.418 \\
\hline
\end{tabular}




\begin{tabular}{|l|l|lllll|}
\hline$\#$ & Glass & T(C) & EC 100 & EC 1000 & EC 10000 & EC 100000 \\
\hline 40 & CVS3-40 & 1449 & 51.709 & 52.416 & 54.181 & 53.999 \\
40 & CVS3-40 & 1350 & 38.797 & 42.829 & 43.638 & 43.502 \\
40 & CVS3-40 & 1250 & 29.763 & 32.566 & 33.286 & 33.273 \\
40 & CVS3-40 & 1150 & 20.916 & 23.107 & 23.722 & .23 .960 \\
\hline
\end{tabular}


10.4 Crystallinity and Liquidus Temperature Results

\begin{tabular}{|c|c|c|c|c|c|c|c|c|c|}
\hline CVS\# & Glass & Que & nched Glass An & alysis & & CC Glass Analy & & $T M$ & Llquidus \\
\hline & & $O M$ & SEM & XRD & $O M$ & SEM & $\mathbf{X R D}$ & & \begin{tabular}{|l|l|} 
Tem & Pha \\
\end{tabular} \\
\hline CVS3-1 & $\begin{array}{l}\text { Base } \\
\text { line }\end{array}$ & NoXI & & & $\begin{array}{l}3.7 \% \mathrm{XI} \\
\text { inhomo }\end{array}$ & spinel & & 1366 & \begin{tabular}{|l|l|}
1153 & sp \\
\end{tabular} \\
\hline CvS3-2 & $60 \mathrm{Si}$ & No XI & & & $\begin{array}{l}\text { very few. } \\
\text { spinel near } \\
\text { crucible }\end{array}$ & & Amourphous & 1500 & 1181 sp \\
\hline CVS3-3 & $45 \mathrm{Si}$ & $\begin{array}{l}\ll<1 \\
\text { undisolved } \\
\text { cluster } \ll .1 \\
\text { spinel }\end{array}$ & & & $\begin{array}{l}2.2 \% \times \mathrm{XL} \\
\text { spinel }+?\end{array}$ & spinel only & & 1213 & 1130 sp \\
\hline CvS3-4 & $40 \mathrm{Si}$ & $\begin{array}{l}2.6 \% \text { spinel, } \\
\text { possibly und } \\
\mathrm{Zx}\end{array}$ & $\begin{array}{l}\text { spinel, (Si, } \mathrm{Zs} \text {, } \\
\mathrm{Ce}, \mathrm{Nd},[\mathrm{Na} \text { ? })\end{array}$ & $\begin{array}{l}5 \text { vol\% XI, } \\
90 \mathrm{w} \% \text { sp, } \\
10 \mathrm{w} \% \mathrm{ZCeO}\end{array}$ & $\begin{array}{l}13.2 \% \text { XI } 2 \\
\text { types }\end{array}$ & $\begin{array}{l}\text { spinel, } \\
\text { (Si,Ca,Nd, } \\
\text { [Na?]), (Si, Zr, } \\
\text { Ce, Nd, } \\
\text { [Na?]), hiCr } \\
\text { sp }\end{array}$ & $\begin{array}{l}\text { 35vol\% XI, } \\
\text { 45w\% CaNdP } \\
\text { O4SiO4, } \\
\text { 35w\%spinel, } \\
\text { 20w\%ZCeO }\end{array}$ & 1155 & $1186 \mid \begin{array}{ll}\mathrm{Ce} \\
\mathrm{Zs} \\
\mathrm{Oy}\end{array}$ \\
\hline CVS3.5 & $37 \mathrm{Si}$ & $\begin{array}{l}3.6 \% \text { spinel, } \\
\text { possibly und. } \\
Z x\end{array}$ & spinel & $\begin{array}{l}3 \text { vol\% XI, } \\
75 w \% \text { NiO, } \\
25 w \% \text { sp }\end{array}$ & $\begin{array}{l}33 \% \text { XI 2 } \\
\text { types (same } \\
\text { as 3-4) }\end{array}$ & $\begin{array}{l}\text { spinel, } \\
\text { (Si,Ca,Nd, } \\
\text { [Na?]), (Si, Zs, } \\
\text { Ce, Nd, [Na?]) }\end{array}$ & $\begin{array}{l}\text { 40vol\% XI, } \\
\text { 30w\%CaNdP } \\
\text { O4SiO4, } \\
\text { 30w\%spinel, } \\
\text { 40w\%ZCCeO }\end{array}$ & 1165 & $1232 \mid \begin{array}{l}\mathrm{Nd} \\
\mathrm{Ce} \\
\mathrm{Zz} \\
\mathrm{Oy}\end{array}$ \\
\hline $\begin{array}{l}\text { CVS3-6 } \\
\text { CVS3-7 }\end{array}$ & $\begin{array}{l}8 B \\
4 B\end{array}$ & $\begin{array}{l}\text { No XI } \\
\text { No XI }\end{array}$ & & & $\begin{array}{l}\text { No XI : } \\
\text { No XI }\end{array}$ & & & $\begin{array}{l}1237 \\
1301\end{array}$ & $\begin{array}{l}1066 \mid ? \\
1132 \text { sp }\end{array}$ \\
\hline CVS3-8 & $22 \mathrm{Na}$ & No XI & & & No XI & & - & 1182 & $1066 \mid \begin{array}{l}\mathrm{Na} \\
\mathrm{Zr} \\
\mathrm{Si}\end{array}$ \\
\hline CVS3-9 & $5 \mathrm{Na}$ & $\begin{array}{l}\text { very small } \\
\text { particles }\end{array}$ & & & $\begin{array}{l}4.4 \% \text { XI } \\
\text { spinel+? }\end{array}$ & spinel, biCrsp & & 1529 & 1374 sp \\
\hline & $7 \mathrm{Li}$ & No XI & & & $\begin{array}{l}\text { <.1\% stars } \\
\text { (spinel?) }\end{array}$ & $\begin{array}{l}\text { spinel, hiCs } \\
\text { sp, hiNi sp }\end{array}$ & & 1153 & \begin{tabular}{|l|l|}
1022 & $\mathrm{Ce}$ \\
1021 & $\mathrm{Sp}$ \\
\end{tabular} \\
\hline $\begin{array}{l}\text { CVS3-11 } \\
\text { CVS3-12 }\end{array}$ & $\begin{array}{l}5 L i \\
0 L i\end{array}$ & $\begin{array}{l}\text { No XL } \\
\text { very small } \\
\text { particles }\end{array}$ & hi Cr spinel & & $\begin{array}{l}\text { No XI } \\
\text { Very high XI } \\
\text { many phases, }\end{array}$ & spinel, hicr sp & & $\begin{array}{l}1257 \\
1557\end{array}$ & \begin{tabular}{|l|l|}
1075 & sp \\
1278 & sp \\
\end{tabular} \\
\hline CvS3-13 & $15 \mathrm{Fe}$ & <.1\% spinel & Spinel & & $\begin{array}{l}5.9 \% \text { tiny } \\
\text { spinel at } \\
\text { bottom, } 4.5 \% \\
\text { larger spinel at } \\
\text { top }\end{array}$ & spinel & $\begin{array}{l}10 \text { vol\% } \\
\text { Spinel }\end{array}$ & 1310 & 1295 sp \\
\hline $\begin{array}{l}\text { CVS3-14 } \\
\text { CVS3-15 }\end{array}$ & $\begin{array}{l}11 \mathrm{Fe} \\
0 \mathrm{Fe}\end{array}$ & $\begin{array}{l}\text { No XI } \\
\text { No XI }\end{array}$ & & & $\begin{array}{l}\text { sp } 2.3 \% \\
\text { no XI }\end{array}$ & & & $\begin{array}{l}1335 \\
1419\end{array}$ & \begin{tabular}{l|l|}
1227 & $\mathrm{sp}$ \\
1111 & $\mathbb{G}$
\end{tabular} \\
\hline
\end{tabular}




\begin{tabular}{|c|c|c|c|c|c|c|c|c|c|c|}
\hline CVS\# & Glass & Quer & nched G & aalysis & & CC Glass Analy & & TM & Llquic & Iddus \\
\hline & & $\mathrm{OM}$ & SEM & $\mathbf{X R D}$ & OM & SEM & $\mathbf{X R D}$ & & $\operatorname{Tem} \mid 1$ & Pha \\
\hline CVS3-16 & $25 \mathrm{Al}$ & $\begin{array}{l}3.8 \% \mathrm{XI}, \\
\text { inhomo }\end{array}$ & Spinel & $\begin{array}{l}10 \text { vol\% XI, } \\
75 w \% \text { sp, } \\
25 \mathrm{w} \% \text { NdZro }\end{array}$ & $\begin{array}{l}\text { Fully XI:? two } \\
\text { distinct phases } \\
\text { maybe more }\end{array}$ & $\begin{array}{l}\text { (Si, Al), (Si, } \\
\mathrm{Al}, \mathrm{Zr}),(\mathrm{Si}, \\
\mathrm{Al}, \mathrm{Zr}, \mathrm{Nd} \\
\mathrm{Fe} \text {, spinel }\end{array}$ & $\begin{array}{l}\text { fully XI, } \\
45 \mathrm{w} \% \mathrm{LiAlSi}, \\
40 \mathrm{w} \% \mathrm{np}, \\
10 \mathrm{w \%} \\
\text { NaNdSi }\end{array}$ & 1516 ? & ? & ? \\
\hline CVS3-17 & $18 \mathrm{Al}$ & $\begin{array}{l}2.2 \% \mathrm{XI}, \\
\text { inhomo }\end{array}$ & & & $\begin{array}{l}2.9 \% \mathrm{XL} \text { seem } \\
\text { to be all spinel }\end{array}$ & $\begin{array}{l}\text { spinel, (Si, } \mathrm{Al}, \\
\text { Nd [dend]), } \\
\text { (Fe, } \mathrm{Al}, \mathrm{Ni} \\
\text { [sp?]) }\end{array}$ & $\begin{array}{l}25 \text { vol\% XI, } \\
50 \text { w\% } \\
\text { NaNdSi, } \\
35 w \% \text { sp }\end{array}$ & 1506)? & $?$ & $?$ \\
\hline CVVS3-18 & $13 \mathrm{Al}$ & $\begin{array}{l}\text { very small } \\
\text { particles } \\
\text { similar to 3-17 }\end{array}$ & & & $\begin{array}{l}1.9 \% \text { XI same } \\
\text { as 3-17 only } \\
\text { smaller }\end{array}$ & & & 1457 & 1293 & sp \\
\hline CVS3-19 & OAI & NoXI & 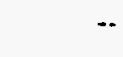 & & No Xz & & & 1309 & $1070)_{s}$ & sp - -1 \\
\hline CVS3-20 & $16 \mathrm{Zr}$ & $\begin{array}{l}3.1 \% \mathrm{XI} \\
\text { inhomo, und } \\
\mathrm{Z} \text { s and other }\end{array}$ & $\mathrm{Z} \times \mathrm{O} 2$ & $\begin{array}{l}\text { 10\% Z-O2, } \\
\text { YZro type }\end{array}$ & $6.7 \% \mathrm{XI}$ & $\begin{array}{l}\mathrm{Zr},(\mathrm{Si}, \mathrm{Fe}, \mathrm{Zr}, \\
\mathrm{Ni})\end{array}$ & $15 \% \mathrm{Z} \times 2, \mathrm{sp}$ & 1456 ? & ? & $?$ \\
\hline CVS3-21 & $12 \mathrm{Zx}$ & $\begin{array}{l}32 \% \text { same as } \\
3-20\end{array}$ & & & $\begin{array}{l}3.6 \% \mathrm{XI} \text { more } \\
\text { than one phase }\end{array}$ & $\begin{array}{l}\mathrm{Zr} \text {, spinel, } \\
\text { hiCr spinel } \\
\text { (spinel in Zr } \\
\text { interstecies) } \\
\text { streaks of Cr } \\
\text { rich area }\end{array}$ & $\begin{array}{l}10 \text { vol\% XI, } \\
60 \mathrm{w} \% \mathrm{ZTO2}, \\
40 \mathrm{w} \% \mathrm{sp}\end{array}$ & 1376 & 1400 & $\mid \begin{array}{l}\mathrm{Zr} \\
\mathrm{SiO} \\
4\end{array}$ \\
\hline & $8 Z$ & No XI & & & $\begin{array}{l}1.6 \% \text { XI same } \\
\text { as } 3.21\end{array}$ & & & 1366 & & sp \\
\hline $\begin{array}{l}\text { CVS3-23 } \\
\text { CVS3-24 }\end{array}$ & $\begin{array}{l}\text { OZx } \\
20 \\
\text { Others }\end{array}$ & $\begin{array}{l}\text { No XI } \\
\text { very sman } \\
\text { particles } \\
\text { inhomo }\end{array}$ & Spinel & Amorphous & $\begin{array}{l}\text { few tiny XI } \\
3.4 \% \text { XI } \\
\text { many phase } \\
\text { inhomo }\end{array}$ & $\begin{array}{l}\text { (Si, } \mathrm{Ca} \text {, Nd, } \\
\mathrm{Ce} \text {, hiCr sp, } \\
\text { spinel }\end{array}$ & $5 \% \mathrm{Sp}$ & $\begin{array}{l}1355 \\
1324\end{array}$ & & sp. \\
\hline $\begin{array}{l}\text { CVS3-25 } \\
\text { CVS3-27 }\end{array}$ & $\begin{array}{l}\text { 70the } \\
\text { ID } \\
15 \mathrm{Fe} \\
\text { Dup } \\
\text { cvs3- } \\
13\end{array}$ & $\begin{array}{l}\text { No XI } \\
\text { scattered } \\
\text { spinel }\end{array}$ & & . & $\begin{array}{l}\text { No XI } \\
\text { Lots of } \\
\text { colorful. } \\
\text { flowers and } \\
\text { Botom agglom } \\
\text { of XI. }\end{array}$ & $\begin{array}{l}\text { hicr sp, } \\
\text { spinel, (Nd, } \\
\text { Si, Ca, Ce), }\end{array}$ & $\begin{array}{l}\text { 10vol\% XI, } \\
\text { 70wt\% Spinel, } \\
\text { 30wt\% } \\
\text { Cas((Si,P,S)O } \\
\text { 4)3F }\end{array}$ & $\begin{array}{l}1411 \\
1308\end{array}$ & $\begin{array}{l}1037 \\
1050 \\
1285\end{array}$ & $\begin{array}{l}\text { hom } \\
\text { sp } \\
\text { sp }\end{array}$ \\
\hline CVS3-28 & $4.4 \mathrm{Bi}$ & NoXI & & & $<0.01$ vol\% sp & $\begin{array}{l}\text { star shaped sp } \\
(\mathrm{Cr}, \mathrm{Ni}, \mathrm{Fe} \\
\mathrm{Mn})\end{array}$ & Amorphous & 1349 & 1141 & sp \\
\hline
\end{tabular}




\begin{tabular}{|c|c|c|c|c|c|c|c|c|c|c|}
\hline CVS\# & Glass & & enched Glas & aalysis & & CC Glass Analy & ysis & $T M$ & Llquid & iddus \\
\hline & & $O M$ & SEM & $\mathrm{XRD}$ & $\mathrm{OM}$ & SEM & $\mathbf{X R D}$ & & $\operatorname{Tem} \mid \mathrm{F}$ & Pha \\
\hline CVS3-29 & $6.4 \mathrm{Bi}$ & No XI & & & $<0.01$ vol\% sp & $\begin{array}{l}\text { star shaped sp } \\
(\mathrm{Cr}, \mathrm{Ni}, \mathrm{Fe}, \\
\mathrm{Mn})\end{array}$ & Amorphous & 1336 & 1136 & sp \\
\hline crs3-30 & $11.4 \mathrm{Bi}$ & i) No XI. & & - & $<0.01$ vol\% sp & $\begin{array}{l}\text { star shaped sp } \\
\left(\mathrm{Cr}, \mathrm{Ni}_{\mathrm{i}}, \mathrm{Fe},\right. \\
\mathrm{Mn} \text { ) }\end{array}$ & Amosphous & 1299 & 1121 & sp \\
\hline CV.S3-31 & $16.4 \mathrm{Bi}$ & i|NoXI & & & few tiny XI & $\begin{array}{l}\text { cube shaped } \\
\text { sp }\left(C_{r}, \mathrm{Ni}\right.\end{array}$ & Amorphous & 1261 & $1109 \mathrm{~s}$ & sp \\
\hline $\begin{array}{l}\text { CVS3-32 } \\
\text { CVS3-33 } \\
\text { CVS3-34 } \\
\text { CVS3-35 } \\
\text { CVS3-36 }\end{array}$ & $\begin{array}{l}9.3 \mathrm{U} \\
3.3 \mathrm{U} \\
6.3 \mathrm{U} \\
\\
12.3 \mathrm{U} \\
\\
15.3 \mathrm{U}\end{array}$ & & & $\begin{array}{l}\text { Amorphous } \\
\text { Amorphous } \\
\text { Amorphous } \\
\text { Amorphous } \\
\text { Amorphous }\end{array}$ & & & $\begin{array}{l}\text { Amorphous } \\
\text { Amorphous } \\
\text { small amt of } \\
\text { Al2O3, cp } \\
\text { small amt of } \\
\text { Ce2O3 and cp } \\
\text { cp, CeO2 type } \\
\text { crystals }\end{array}$ & \begin{tabular}{|l|}
1388 \\
1410 \\
1410 \\
1381 \\
1372 \\
\end{tabular} & & \\
\hline CVS3-37 & $3 P$ & No XI & & Amorphous & $<0.01$ vol\% & $\begin{array}{l}\mathrm{sp}(\mathrm{Cr}, \mathrm{Ni}, \mathrm{Fe}, \\
\mathrm{Mn})\end{array}$ & $\begin{array}{l}2 \text { vol\% XI, } \\
\text { Na3Nd(PO4)2 } \\
\text {, Li3PO4, } \\
\text { NdPO4 }\end{array}$ & \begin{tabular}{|l|}
1378 \\
\end{tabular} & 1175 & 5 \\
\hline CVS3-38 & $5 P$ & No XI & & $\begin{array}{l}1 \text { vol\% XI } \\
\text { NaNdPO4 }\end{array}$ & 0.21 vol\% & $\begin{array}{l}\text { Phase } \\
\text { separated } \\
\text { region of } \\
\text { NaCaNdCeFe, } \\
\text { sp, possible } \\
\text { Li3PO4 }\end{array}$ & $\begin{array}{l}8 \text { vol\% Xl, } \\
\text { Na3Nd(PO4)2 } \\
\text {.Li3PO4, } \\
\text { NdPO4, sp }\end{array}$ & 1391 & $\left.1171\right|_{s}$ & sp \\
\hline CVS3-39 & $7 \mathrm{P}$ & No XI & & $\begin{array}{l}3 \text { vol\% XI, } \\
\text { NaNdPO4 }\end{array}$ & 1.58 vol\% & $\begin{array}{l}\text { Phase } \\
\text { separated } \\
\text { region of } \\
\text { NaCaNdLaCe } \\
\text { FePNi, sp, } \\
\text { possible } \\
\text { Li3PO4 }\end{array}$ & $\begin{array}{l}17 \text { vol\% XI, } \\
\text { Na3Nd(PO4)2 } \\
\text { Li3PO4, } \\
\text { NdPO4, sp }\end{array}$ & 1408 & 1168 & sp \\
\hline Cvs3-40 & $9 P$ & No XI. & $\begin{array}{l}\text { phase } \\
\text { separated }\end{array}$ & $\begin{array}{l}7 \text { vol\% XI, } \\
\text { NaNdPO4 }\end{array}$ & 3.19 vol\% & $\begin{array}{l}\text { Phase } \\
\text { separated } \\
\text { region of } \\
\text { NaNdCaPFe, } \\
\text { sp, possible } \\
\text { Li3PO4 }\end{array}$ & $\begin{array}{l}22 \text { vol\% XI, } \\
\text { Na3Nd(PO4)2 } \\
\text { Ii3PO4, } \\
\text { NdPO4, sp }\end{array}$ & 1417 & & $\begin{array}{l}\mathrm{Zx} \\
\mathrm{Re} \\
\mathrm{Oy}\end{array}$ \\
\hline
\end{tabular}


PVTD-C95-02:01E/J

10.5 PCT Normalized Releases for Each Glass

\begin{tabular}{|c|c|c|c|c|c|c|c|c|c|c|c|}
\hline \# & CVS & Si & $B$ & $\mathrm{Na}$ & $\mathrm{Li}$ & $\mathrm{pH}$ & $\operatorname{ccc}$ & B & $\operatorname{coc} N$ & Li & $\operatorname{cccpH}$ \\
\hline 1 & CVS3-1 & 0.160 & 0.422 & 0.400 & 0.383 & 11.20 & 0.152 & 0.294 & 0.354 & 0.361 & 11.15 \\
\hline & CVS3-2 & 0.132 & 4.803 & 0.306 & 0.360 & 10.80 & 0.131 & 0.262 & 0.286 & 0.328 & 10.77 \\
\hline 3 & CVS3-3 & 0.202 & 0.450 & 0.609 & 0.447 & 11.61 & 0.206 & 0.450 & 0.606 & 0.477 & 11.63 \\
\hline & CVS3-4 & 0.254 & 0.654 & 0.907 & 0.595 & 11.88 & 0.359 & 0.430 & 1.381 & 908 & 11.88 \\
\hline .5 & CVS3-5 & 0.271 & 0.627 & 1.174 & 0.620 & 12.03 & 0.479 & 1.216 & 2.237 & 1.300 & 12.30 \\
\hline 6 & CVS3-6 & 0.151 & 0.309 & 0.296 & 0.346 & 10.23 & 0.144 & 0.273 & 0.265 & 0.302 & 10.17 \\
\hline 7 & CVS3-7 & 0.150 & 0.264 & 0.307 & 0.326 & 11.73 & 0.137 & 0.241 & 0.278 & 0.295 & 10.59 \\
\hline 8 & CVS3-8 & 0.585 & 1.266 & 2.625 & 1.643 & 12.45 & 0.580 & 1.548 & 2.462 & 1.477 & 12.42 \\
\hline$y$ & CVS3-9 & 0.100 & 0.209 & 0.034 & 0.355 & 10.24 & 0.101 & 0.627 & 0.045 & 0.345 & 10.21 \\
\hline 10 & CVS3-10 & 0.334 & 0.703 & 0.824 & 0.865 & 11.85 & 0.319 & 0.000 & 0.732 & 1.324 & 11.79 \\
\hline 11 & CVS3-11 & 0.224 & 0.429 & 0.567 & 0.540 & 11.58 & 0.229 & 0.000 & 0.502 & 0.844 & 11.47 \\
\hline 12 & CVS3-12 & 0.113 & 0.100 & 0.314 & 0.000 & 10.79 & 0.114 & 0.268 & 0.299 & 0.000 & 10.64 \\
\hline 13 & CVS3-13 & 0.162 & 0.804 & 0.336 & 0.380 & 11.02 & 0.160 & 0.583 & 0.332 & 0.364 & 11.05 \\
\hline 18 & 3-14 & 0.155 & 0.301 & 0.346 & 0.356 & 11.06 & 0.200 & 0.503 & 0.614 & 0.554 & 11.51 \\
\hline 15 & CVS3-15 & 0.187 & 0.466 & 0.585 & 0.529 & 11.54 & 0.139 & 0.306 & 0.320 & 0.333 & 11.14 \\
\hline 16 & CVS3-16 & 0.120 & 0.268 & 0.079 & 0.511 & 10.35 & 0.117 & 1.250 & 0.037 & 0.418 & 9.46 \\
\hline 17 & CVS3-17 & 0.118 & 0.523 & 0.129 & 0.422 & 10.64 & 0.160 & 0.563 & 0.126 & 0.476 & 10.48 \\
\hline 18 & CVS3-18 & 0.111 & 0.643 & 0.199 & 0.304 & 10.74 & 0.112 & 0.302 & 0.199 & 0.301 & 10.70 \\
\hline 19 & CVS3-19 & 0.842 & 2.022 & 1:717 & 1.640 & 11.43 & 0.743 & .2 .220 & 1.470 & 1.398 & 11.30 \\
\hline 20 & CVS3-20 & 0.110 & 0.181 & 0.298 & 0.331 & 11.03 & 0.135 & 0.804 & 0.364 & 0.396 & 11.18 \\
\hline 21 & CVS3-21 & 0.097 & 0.196 & 0.254 & 0.301 & 11.03 & 0.124 & 0.530 & 0.322 & 0.359 & 11.14 \\
\hline 22 & CVS3-22 & 0.119 & 0.324 & 0.303 & 0.310 & 11.07 & 0.118 & 0.432 & 0.303 & 0.330 & 10.97 \\
\hline 23 & CVS3-23 & 0.232 & 0.402 & 0.562 & 0.502 & 11.28 & 0.228 & 0.515 & 0.528 & 0.481 & 11.17 \\
\hline 24 & CVS3-24 & 0.151 & 0.261 & 0.380 & 0.355 & 11.07 & 0.155 & 0.362 & 0.342 & 0.356 & 10.97 \\
\hline 2 & CVS3-25 & 0.161 & 0.209 & 0.420 & 0.384 & 11.26 & 0.156 & 0.338 & 0.382 & 0.368 & 11.18 \\
\hline 26 & CVS3-27 & 0.157 & 0.342 & 0.329 & 0.358 & 10.98 & 0.159 & 0.704 & 0.391 & 0.395 & 11.15 \\
\hline 27 & CVS3-28 & 0.160 & 0.305 & 0.400 & 0.382 & 11.21 & 0.157 & 1.094 & 0.366 & 0.365 & 11.09 \\
\hline 28 & CVS3-29 & 0.189 & 0.241 & 0.432 & 0.411 & 11.22 & 0.155 & 0.531 & 0.381 & 0.376 & 11.16 \\
\hline 29 & CVS3-30 & 0.183 & 0.338 & 0.420 & 0.397 & 11.23 & 0.159 & 0.463 & 0.379 & 0.385 & 11.03 \\
\hline 30 & CVS3-31 & 0.202 & 0.261 & 0.465 & 0.451 & 11.25 & 0.156 & 2.311 & 0.376 & 0.382 & 11.05 \\
\hline 31 & CVS3-32 & 0.159 & 0.487 & 0.326 & 0.370 & 10.88 & 0.155 & 0.412 & 0.289 & 0.367 & 10.84 \\
\hline 32 & CVS3-33 & 0.149 & 0.403 & 0.335 & 0.338 & 10.95 & 0.144 & 0.368 & 0.299 & 0.334 & 10.87 \\
\hline 33) & CVS3-34 & 0.154 & 0.411 & 0.331 & 0.357 & 10.89 & 0.151 & 0.394 & 0.297 & 0.369 & 10.88 \\
\hline 34 & CVS3-35 & 0.163 & 0.422 & 0.325 & 0.395 & 10.78 & 1.740 & 0.441 & 0.343 & 0.468 & 10.9 \\
\hline 35 & CVS3-36 & 0.165 & 0.543 & 0.304 & 0.393. & 10.80 & 0.174 & 0.523 & 0.313 & 0.458 & 10.8 \\
\hline 36 & CVS3-37 & 0.151 & 0.547 & 0.370 & 0.188 & 10.52 & 0.152 & 0.294 & 0.361 & 0.354 & 10.96 \\
\hline 37 & CVS3-38 & 0.147 & 0.418 & 0.327 & 0.292 & i1.03 & 0.120 & 0.370 & 0.283 & 0.326 & 10.90 \\
\hline 3 & CVS3-39 & 0.121 & 0.209 & 0.252 & 0.234 & 10.81 & 0.130 & 0.242 & 0.286 & 0.681 & 10.89 \\
\hline 39 & CVS3-40 & 0.141 & 0.225 & 0.248 & 0.205 & 10.59 & 0.168 & 0.290 & 0.359 & 1.055 & 10.7 \\
\hline
\end{tabular}

